C:-

\begin{tabular}{|c|c|c|}
\hline ENGINEERING CHANGE NOTICE & Page 1 of 3 & 1. ECN No 623790 \\
\hline
\end{tabular}

\begin{tabular}{|c|c|c|c|c|c|c|}
\hline \multirow{3}{*}{$\begin{array}{l}\text { 2. ECN Category } \\
\text { (mark one) } \\
\text { Supplemental } \\
\text { Direct Revision } \\
\text { Change ECN } \\
\text { Temporary } \\
\text { Standby } \\
\text { Supersedure } \\
\text { Cancel/Void }\end{array}$} & \multirow{3}{*}{$\begin{array}{r}{[]} \\
{[x]} \\
{[]} \\
{[]} \\
{[]} \\
{[]} \\
{[]}\end{array}$} & \multicolumn{2}{|c|}{$\begin{array}{l}\text { 3. Originator's Name, Organization, MSIN, } \\
\text { and Telephone No. } \\
\text { C. A. Petersen } 73510 \text { H5-27 } \\
372-0745\end{array}$} & \multicolumn{2}{|c|}{ [] res [x] No } & $\begin{array}{l}\text { 4. Date } \\
7 / 17 / 96\end{array}$ \\
\hline & & \multicolumn{2}{|c|}{$\begin{array}{l}\text { 5. Project Title/No./Work order No. } \\
\text { TWRS }\end{array}$} & \multicolumn{2}{|c|}{$\begin{array}{c}\text { 6. Bldg./Sys./Fac. No. } \\
\text { NA }\end{array}$} & $\begin{array}{r}\text { 7. Approval Des } \\
\text { NA }\end{array}$ \\
\hline & & \multicolumn{2}{|c|}{$\begin{array}{l}\text { 8. Document Numbers Changed by this ECN } \\
\text { (ineludes sheet no. and rev.) } \\
\text { WHC-SD-WM-TI-699, Rev. } 0\end{array}$} & \multicolumn{2}{|c|}{$\begin{array}{l}\text { 9. Related ECN No(s). } \\
612662 \\
\end{array}$} & $\begin{array}{l}\text { 10. Related PO No. } \\
\text { NA }\end{array}$ \\
\hline \multirow{2}{*}{\multicolumn{2}{|c|}{$\begin{array}{l}\text { 11a. Modification Work } \\
\text { [] Yes (fill out B(k. } \\
11 \mathrm{~b}) \\
{[\mathrm{X}] \text { No (NA B(ks, 11b. }} \\
11 \mathrm{c}, 11 \mathrm{~d})\end{array}$}} & \multirow[t]{2}{*}{$\begin{array}{l}\text { 11b. Work Package } \\
\text { No. } \\
\text { N4 ys }\end{array}$} & \multicolumn{2}{|c|}{$\begin{array}{l}\text { 11c. Modification work Complete } \\
\qquad N A\end{array}$} & \multicolumn{2}{|c|}{$\begin{array}{l}\text { 11d. Restored to Original Condi- } \\
\text { tion (Temp. or standby ECN only) } \\
\qquad N A\end{array}$} \\
\hline & & & Cos. E & & $\operatorname{cog}$. & e \\
\hline
\end{tabular}

12. Deseription of Change

Direct revision of document to Revision 1 .

13a. Just ification (mark one)

Criteria Change [] Design Improvement As-Found Facilitate const

13b. Justification Details

Comments incorporated from review of Revision 0 of document.

14. Distribution (include name, MSIN, and no. of copies)

see attached list. 


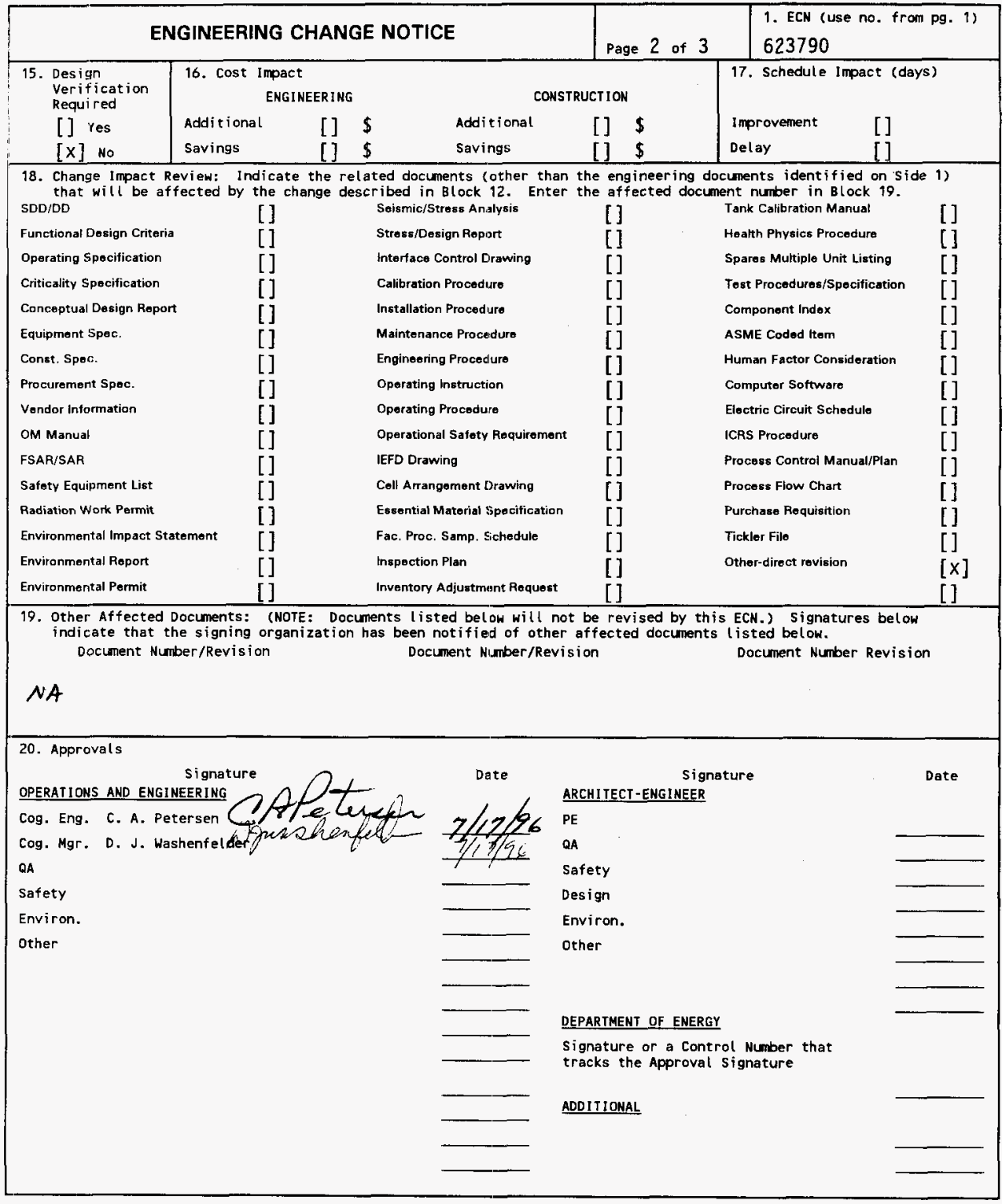




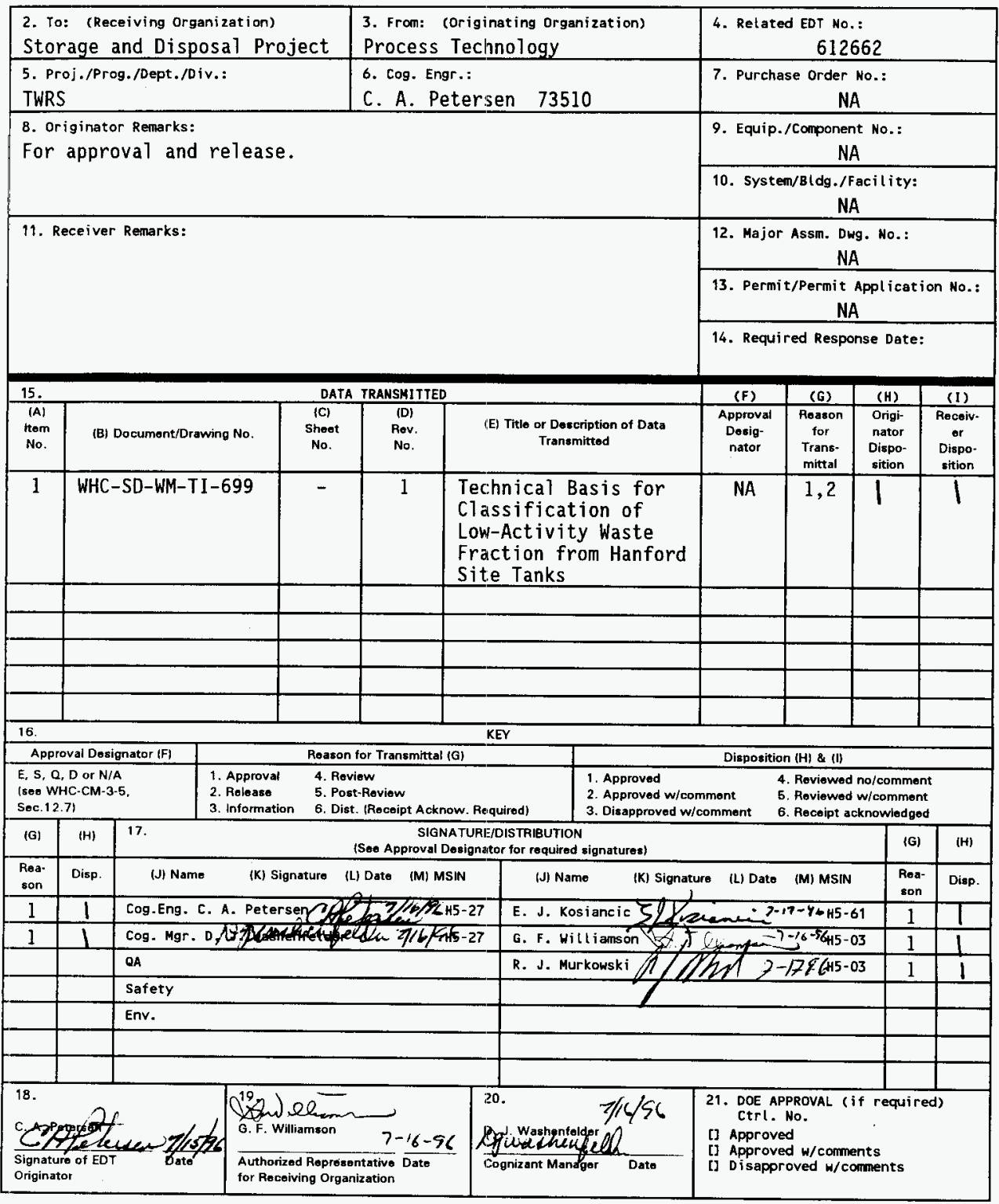




\title{
Technical Basis for Classification of Low-Activity Waste Fraction from Hanford Site Tanks
}

\author{
C. A. Petersen \\ Westinghouse Hanford Company, Richland, WA 99352 \\ U.S. Department of Energy Contract DE-AC06-87RL10930 \\ EDT/ECN: 612673 \\ UC: 721 \\ Org Code: 73510 \\ Charge Code: D4DB7 \\ B\&R Code: EW3130010 \\ Tota1 Pages: 137
}

Key Words: low-activity waste, classification, U.S. Nuclear Regulatory Commission, incidental waste

Abstract: The overall objective of this report is to provide a technical basis to support a U.S. Nuclear Regulatory Commission determination to classify the low-activity waste from the Hanford Site single-shell and double-she11 tanks as "incidental" wastes after removal of additional radionuclides and immobilization. The proposed processing method, in addition to the previous radionuclide removal efforts, will remove the largest practical amount of total site radioactivity, attributable to high-level waste, for disposal in a deep geologic repository. The remainder of the waste would be considered "incidental" waste and could be disposed onsite.

TRADEMARK DISCLAIMER. Reference herein to any specific commercial product, process, or service by trade name, trademark, manufacturer, or otherwise, does not necessarily constitute or imply its endorsement, recommendation, or favoring by the United States Government or any agency thereof or its contractors or subcontractors.

Printed in the United States of America. To obtain copies of this document, contact: WHC/BCS Document Control Services, P.O. Box 1970, Mailstop H6-08, Richland HA 99352, Phone (509) 372-2420; Fax (509) 376-4989.
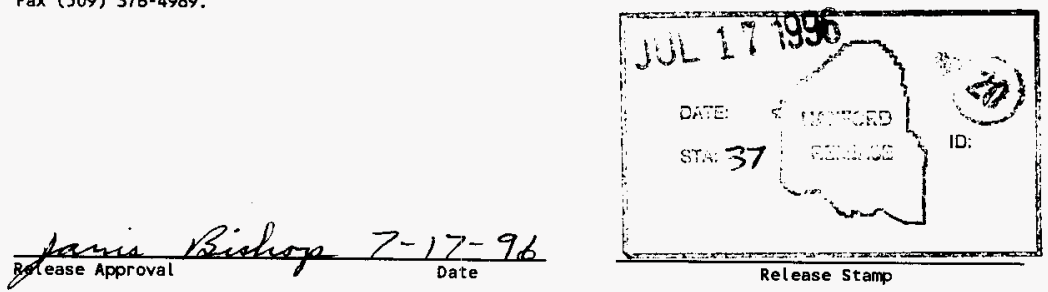

\section{Approved for Public Release}


(2) Title

Technical Basis for Classification of Low-Activity Waste Fraction from Hanford Site Tanks

CHANGE CONTROL RECORD

\begin{tabular}{|c|c|c|c|c|}
\hline \multirow{2}{*}{ (3) } & \multirow{2}{*}{ Revision } & \multirow{2}{*}{ (4) Description of Change - Replace, Add, and Delete } & \multicolumn{2}{|c|}{ Authorized for Release } \\
\hline & & & Engr. & (6) Cog. Mgr. \\
\hline & 0 & (7) Initial release-EDT $\# 612662$ & C:A. Peterseren & 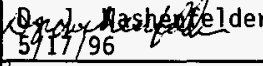 \\
\hline & 1 PS & $\begin{array}{l}\text { Document update. Replace all pages. } \\
\text { ET } 612673 \text { E }\end{array}$ & $\begin{array}{l}\text { C.APGetersen } \\
7 / 15 / 96\end{array}$ & 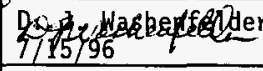 \\
\hline
\end{tabular}


WHC-SD-WM-TI-699, Rev. 1

\title{
Technical Basis for Classification of Low-Activity Waste Fraction from Hanford Site Tanks
}

\author{
For the
}

Tank Waste Rernediation System

Disposal Engineering

July 1996

Originally Prepared By:

Disposal Engineering

Westinghouse Hanford Company

Richland, Washington

Revised By:

Los Alamos Technical Associates, Inc. and BNFL, INC.

Richland, Washington

For:

Westinghouse Hanford Company

Richland, Washington 
WHC-SD-WM-TI-699, Rev. 1

This page intentionally left blank. 


\section{EXECUTIVE SUMMARY}

\section{INTRODUCTION}

The Hanford Site tank wastes were produced through the years 1944 to 1988 by reprocessing irradiated nuclear fuel (containing $98,100 \mathrm{Mg}$ of uranium). The resulting aqueous wastes were accumulated in underground storage tanks. Over the years, these tank wastes were treated to reduce the volume, to minimize the volume of liquid in single-shell tanks (SSTs), and to remove a portion of the radionuclides.

In 1989, the U.S. Nuclear Regulatory Commission (NRC) evaluated a U.S. Department of Energy (DOE) proposal for pretreatment and disposal of Hanford Site double-shell tank (DST) reprocessed liquid wastes (Bernero 1989) and agreed that, if treated as described by DOE, a portion the wastes would be classified as "incidental" wastes. This classification would remove the waste from the high-level waste (HLW) disposal licensing authority of the NRC and would permit disposal of the wastes under DOE requirements in shallow land disposal facilities. This proposal was based on the preferred alternative in the Environmental Impact Statement for the Disposal of Hanford Defense, Tank and Transuranic Wastes (HDWEIS) (DOE 1987). The proposal included removal of ${ }^{137} \mathrm{Cs}$ from Neutralized Current Acid Waste and Complexant Concentration (CC) waste supernatants and immobilizing the resultant liquid as a grout for permanent disposal in near-surface vaults. The proposal also included transuranic (TRU) element removal from Neutralized Cladding Removal Waste and Plutonium Finishing Plant wastes sludges. SSTs were not included to allow further study on "if" and "how" SST wastes would be disposed. 
Since completion of the original agreement between the NRC and the DOE, several changes have occurred that impact the tank waste processing plan. The main changes include plans to retrieve SST waste and concerns about grout as a low-activity waste (LAW) form. These changes have occurred based on public and governmental agency review of the processing scheme for disposal of Hanford Site tank wastes. In addition, the DOE is pursuing privatization of the tank waste pretreatment and immobilization functions at the Hanford Site. Because of these changes, and additional information acquired from tank waste characterization, DOE believes it now has information sufficiently developed and documented to revisit the DST waste classification and to seek SST waste classification.

\section{REPORT OBJECTIVE}

The overall objective of this report is to provide a technical basis to support an NRC determination to classify the LAW (existing supernatants, plus wash solutions and dissolved salt cake) from the Hanford Site single-shell and double-shell tanks as "incidental" wastes after removal of additional radionuclides and inmobilization. The proposed processing method, in addition to the previous radionuclide removal efforts, will remove the largest practical amount of total site radioactivity, attributable to $\mathrm{HLW}$, for disposal in a deep geologic repository. The remainder of the waste would be considered "incidental" waste and could be disposed onsite.

This report assesses the degree of radionuclide removal from the tank liquid wastes against the following three guidelines (Bernero 1993): 
1. The "waste has been processed (or will be further processed) to remove key radionuclides to the maximum extent technically and economically practical."

2. The "waste will be incorporated in a solid physical form at a concentration that does not exceed the applicable concentration limits for Class $\mathrm{C}$ low-level waste as set out in 10 CFR Part 61."

3. The solid, immobilized waste will be managed, pursuant to the Atomic Energy Act of 1954 , so that safety requirements comparable to the performance objectives set out in 10 CFR Part 61 are satisfied.

Key radionuclides are considered to be: ${ }^{137} \mathrm{Cs},{ }^{90} \mathrm{Sr}, \mathrm{TRU},{ }^{99} \mathrm{Tc},{ }^{79} \mathrm{Se},{ }^{14} \mathrm{C},{ }^{129} \mathrm{I},{ }^{3} \mathrm{H},{ }^{126} \mathrm{Sn}$, and the uranium isotopes. These radionuclides are of interest because they represent 99.9 percent of the inventory, are specifically identified in 10 CFR Part 61, or are potential detractors to disposal system performance because they (or their daughter products) may exceed the dose limits for a short term intruder scenario (100 mrem/yr) or a long term drinking water scenario ( $4 \mathrm{mrem} / \mathrm{yr}$ ). The key radionuclides listed are candidates for removal to the maximum extent technically and economically practical. 


\section{SUMMARY OF RESULTS}

Of the estimated $422 \mathrm{MCi}$ of key radionuclides that entered the Hanford Site tanks, $243 \mathrm{MCi}$ have decayed during storage and approximately $87 \mathrm{MCi}$ have been removed by previous processing, the bulk of which will eventually be disposed in a deep geologic repository. The remaining $92 \mathrm{MCi}$ are addressed in this report.

Sludge washing and solids/liquid separation operations are intrinsic to all planned processing scenarios for separation of the high-activity sludges from the liquid phase. Separation of solids from supernatants by centrifuges and filters has been practiced in production operations at the Hanford Site since the 1940's. Solid/liquid separation by in-tank settle/decant has been practiced in tank farm operations over the last 50 years. Solids/liquid separation, which includes enhanced sludge washing, of the retrieved tank wastes will leave approximately $54 \mathrm{MCi}$ in the solids slurry to be treated as HLW and approximately $38 \mathrm{MCi}$ in the low-activity liquid phase before any additional radionuclide removal.

Cesium represents 91 percent of the curies ( $34 \mathrm{MCi}$ soluble cesium) in the liquid fraction after solids/liquid separations have been performed. Removal of ${ }^{137} \mathrm{Cs}$ from the liquid fraction for return to the HLW fraction is technically and economically practical.

For this analysis, the ${ }^{137} \mathrm{Cs}$ removal is based on the use of an "in-plant" cesium ion exchange technology considered to have limited technical risk but relatively high cost. Assuming a single-cycle ion exchange system with a design basis of 99 percent theoretical removal and an overall operational efficiency of 97 percent, an estimated $33 \mathrm{MCi}{ }^{137} \mathrm{Cs}$ is technically 
practical to remove from the liquid fraction. However, an evaluation of the cost to remove cesium from all the retrieved wastes shows that for dilute feeds (cesium concentration $<0.05 \mathrm{Ci} / \mathrm{L})$ the cost of further curie removal increases dramatically making further removal not economically practical. Processing of all feeds $>0.05 \mathrm{Ci}{ }^{137} \mathrm{Cs}$ per liter would leave $5 \mathrm{MCi}$ remaining in the LAW (i.e., $29 \mathrm{MCi}{ }^{137} \mathrm{Cs}$ separated).

Removal of TRU and ${ }^{90} \mathrm{Sr}$ from all the tank waste is not economically practical. However, selective removal of TRU from three tanks will be necessary to meet the Class C TRU limit. Laboratory testing on actual tank wastes indicate that the liquid fraction can be treated to produce $<100 \mathrm{nCi} / \mathrm{g}$ LAW glass by hydroxide adjustments. There are also indications that some of the soluble ${ }^{90} \mathrm{Sr}$ will co-precipitate during this hydroxide adjustment process. Additional ${ }^{90} \mathrm{Sr}$ removal is not economically practical. The estimated concentration of ${ }^{90} \mathrm{Sr}$ in the LAW feed is below the Class $\mathrm{C}$ limit for ${ }^{90} \mathrm{Sr}$.

Technology exists for removal of ${ }^{99} \mathrm{Tc}$, but is considered not to be technically practical. The estimated maximum concentration of ${ }^{99} \mathrm{Tc}$ in the LAW feed is within the Class A limit for ${ }^{99} \mathrm{Tc}$. However, removal of ${ }^{99} \mathrm{Tc}$ may be required to meet disposal system performance objectives. A performance assessment will identify areas of concern for long-term release of radionuclides to the environment from the disposal system. Disposal design features will be evaluated that include waste form corrosion rate, waste form dimensions, engineered barriers, modification of water chemistry, chemical retardants, and moisture diverters. Upon completion of the disposal system evaluation, mitigating measures, such as ${ }^{99} \mathrm{Tc}$ removal and/or disposal system barriers, will be finalized. 
No technologies have been adequately demonstrated for removal of ${ }^{3} \mathrm{H},{ }^{14} \mathrm{C},{ }^{79} \mathrm{Se}$, or ${ }^{129} \mathrm{I}$ that can be considered technically practical. These are low concentration isotopes and some will most likely be removed from the LAW in the offgas system as a result of the vitrification process. Some ${ }^{79} \mathrm{Se}$ removal may be required to meet disposal system performance objectives.

\section{CONCLUSION}

The proposed new determination would include processing the tank wastes to accomplish the following:

1. Radionuclide removal to the maximum extent technically and economically practical will leave no more than $5 \mathrm{MCi}{ }^{137} \mathrm{Cs}$ and 3.4 $\mathrm{MCi}{ }^{90} \mathrm{Sr}$ in the LAW.

2. Remove TRU as required (i.e., removal from $3 \mathrm{CC}$ tanks) to ensure all solidified LAW is $<100 \mathrm{nCi}$ TRU/g.

3. Meet all disposal requirements including those defined by the performance assessment. 
It is concluded that cesium removal from liquid supernatants and TRU removal from CC tanks before LAW immobilization ${ }^{1}$ represents radionuclide removal to the maximum extent practical. Therefore, these liquids could be considered "incidental" waste provided the immobilized LAW qualify for disposal in a shallow land disposal facility under DOE waste management requirements comparable to $10 \mathrm{CFR}$ Part 61 requirements.

${ }^{1}$ This report assumes that the LAW form for disposal is a glass waste form. Therefore, the concentrations of the radionuclides are concentrations using a vitrification process. 
WHC-SD-WM-TI-699, Rev. 1

This page intentionally left blank. 


\section{CONTENTS}

1.0 INTRODUCTION $\ldots \ldots \ldots \ldots \ldots \ldots \ldots \ldots \ldots \ldots \ldots \ldots \ldots \ldots \ldots \ldots \ldots \ldots .1$

1.1 OBJECTIVE $\ldots \ldots \ldots \ldots \ldots \ldots \ldots \ldots \ldots \ldots \ldots \ldots \ldots \ldots \ldots \ldots \ldots \ldots \ldots .11$

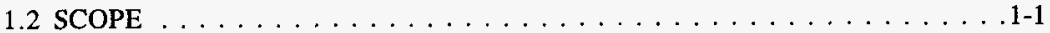

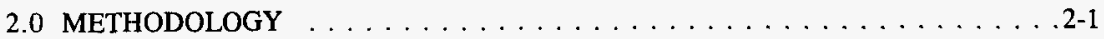

2.1 WASTE CLASSIFICATION FOR THE HANFORD SITE DOUBLE-SHELL

TANK WASTE . . . . . . . . . . . . . . . . . . . 2-1

2.1.1 U.S. Nuclear Regulatory Commission Determination for Hanford Site Double-Shell Tank Waste . . . . . . . . . . . . . . . 2-2

2.1.2 Modification of the Tank Waste Processing Scheme . . . . . . . . . 2-2

2.2 NUCLEAR REGULATORY COMMISSION WASTE CLASSIFICATION $\ldots$. 2-5

2.2.1 Definition of Low-Level Waste $\ldots \ldots \ldots \ldots \ldots \ldots \ldots . . \ldots \ldots$

2.2.2 Definition of High-Level Waste . . . . . . . . . . . . . . 2-6

2.2.3 U.S. Nuclear Regulatory Commission Guidelines for Classification of Hanford Site Wastes . . . . . . . . . . . . . . . . 2-6

2.3 INTERPRETATION OF U.S. NUCLEAR REGULATORY COMMISSION GUIDELINES . . . . . . . . . . . . . . . . . . . . . 2-7

2.3.1 Definition of Technically Practical and Economically Practical . . . . . 2-7

2.3.2 10 CFR Part 61 Class C Concentration Limits . . . . . . . . . . . . 2-9

2.3.3 10 CFR Part 61 Disposal Performance Objectives . . . . . . . . . . . 2-9

2.3.4 Radionuclides of Interest $\ldots \ldots \ldots \ldots \ldots \ldots \ldots \ldots . . \ldots \ldots$

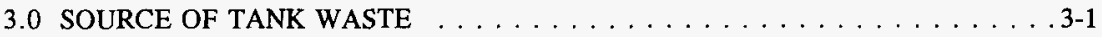

3.1 TANK WASTE INVENTORY FOR PRETREATMENT . . . . . . . . . . 3-1

3.2 INVENTORY UNCERTAINTIES . . . . . . . . . . . . . . . . . 3-3

4.0 RADIONUCLIDE SEPARATIONS TECHNOLOGIES $\ldots \ldots \ldots \ldots \ldots \ldots$. . . . .

4.1 BASELINE PRETREATMENT PROCESS . . . . . . . . . . . 4-1

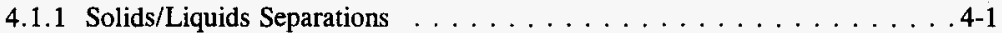

4.2 TECHNOLOGY OPTIONS . . . . . . . . . . . . . . . . 4-3

4.2 .1 Cesium Removal . . . . . . . . . . . . . . . . . 4-3

4.2.2 Strontium Removal . . . . . . . . . . . . . . . . . . . 4-11

4.2 .3 Transuranic Removal . . . . . . . . . . . . . . . . . . . . . . 4-14

4.2.4 Technetium-99 Removal . . . . . . . . . . . . . . . . . . . . . . 4-17

4.2.5 Selenium-79 Removal . . . . . . . . . . . . . . . . . . 4-20

4.2.6 Carbon-14 Removal . . . . . . . . . . . . . . . . . . 4-21

4.2 .7 Iodine-129 Removal . . . . . . . . . . . . . . . . . . . . . . 4-22

4.2 .8 Tritium Removal . . . . . . . . . . . . . . . . . . . . . 4-23

4.2 .9 Tin Removal . . . . . . . . . . . . . . . . . . . . . 4-23

4.2 .10 Uranium Removal . . . . . . . . . . . . . . . . . . 4-23

4.2.11 Radionuclide Removal Technology Options Summary . . . . . . . . 4-24 
5.0 RADIONUCLIDE SEPARATIONS TO MEET THE U.S. NUCLEAR REGULATORY COMMISSION GUIDELINES . . . . . . . . . . . . . . 5-1 5.1 REMOVE RADIONUCLIDES TO THE MAXIMUM EXTENT PRACTICAL . 5-1 5.2 MEET CLASS C CONCENTRATION LIMITS . . . . . . . . . . . . . . 5-2 5.3 MEET DISPOSAL PERFORMANCE OBJECTIVES . . . . . . . . . . . 5-3 5.4 PROPOSED DETERMINATION OF HANFORD SITE TANK WASTE

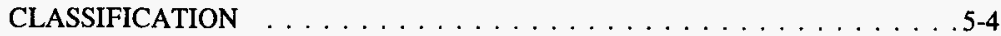

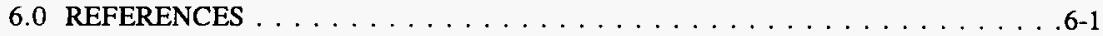

Appendix A - Correspondence $\ldots \ldots \ldots \ldots \ldots \ldots \ldots \ldots \ldots \ldots$ A-1

Appendix B - Cost Estimates $\ldots \ldots \ldots \ldots \ldots \ldots \ldots \ldots$ B-1

Appendix $\mathbf{C}$ - Source of Tank Waste at the Hanford Site $\ldots \ldots \ldots \ldots$-1 


\section{LIST OF FIGURES}

2-1. Timeline of Classification of Low-Activity Waste

Fraction in Hanford Site Tanks . . . . . . . . . . . . . . 2-3

2-2. Logic Diagram for Determining Classification of Tank Waste. $\ldots \ldots \ldots \ldots$ 2-8

3-1. Estimated Hanford Site Tank Waste Radionuclide Inventory $\ldots \ldots \ldots \ldots \ldots$ 3-2

4-1. Waste Volume to Curie Content Comparison . . . . . . . . . . . . . . 4-4

4-2. Cost per Curie Cesium Recovered versus Cesium Concentration in the Feed . . . . 4-7

\section{LIST OF TABLES}

2-1. Radionuclides of Interest in meeting the U.S. Nuclear Regulatory Commission

"Incidental" Waste Guidelines . . . . . . . . . . . . . . . . . 2-10

3-1. Tank Waste Remediation System Processing Inventory $\ldots \ldots \ldots \ldots \ldots$ 3-3

4-1. Inventory For Additional Radionuclide Removals $\ldots \ldots \ldots \ldots \ldots$. . . . . . .

4-2. Concentrations of Cesium for Processing $\ldots \ldots \ldots \ldots \ldots \ldots \ldots \ldots$

4-3. Summary Table of Technology Maturity Assessment $\ldots \ldots \ldots \ldots$. . . . . . .

4-4. Summary Table of Costs for Technically Practical Radionuclide Removal Technology Options . . . . . . . . . . . . . . . . . . 4-26

5-1. Maximum Practical Key Radionuclide Removal . . . . . . . . . . . . 5-1

5-2. Solidified Waste Radionuclide Concentrations After Supernatant

Separations Versus 10 CFR Part 61 Limits. . . . . . . . . . . . 5-2

5-3. Comparison of Previous and Proposed

U.S. Nuclear Regulatory Commission Determinations . . . . . . . . . . . . 5-4 


\section{LIST OF TERMS AND DEFINITIONS}

\section{Terms}

\begin{tabular}{ll} 
ANL & Argonne National Laboratory \\
ANPR & Annual Notice of Proposed Rulemaking \\
CAW & Current acid waste \\
CC & Complexant concentrate \\
CFR & Code of Federal Regulation \\
CST & Crystalline silicotitanate \\
DF & Decontamination factor \\
DOE & U.S. Department of Energy \\
DSS & Double-shell slurry \\
DSSF & Double-shell slurry feed \\
DST & Double-shell tank \\
Ecology & Washington State Department of Ecology \\
EIS & Environmental Impact Statement \\
ETF & Effluent Treatment Facility \\
FY & fiscal year \\
HAPO & Hanford Atomic Products Operations \\
HDW-EIS & Final Environmental Impact Statement for the Disposal of Hanford \\
& Defense, High-Level Transuranic and Tank Wastes \\
HLW & High-level waste \\
LAW & Low-activity waste \\
LLW & Low-level waste \\
NCAW & Neutralized current acid waste \\
NRC & U.S. Nuclear Regulatory Commission \\
PA & Performance Assessment \\
PFP & Plutonium Finishing Plant \\
PUREX & Plutonium-uranium extraction \\
REDOX & Reduction Oxidation \\
SALDS & State Approved Land Disposal Site \\
SOLEX & Solvent extraction \\
SREX & Strontium extraction \\
SRS & Savannah River Site \\
SST & Single-shell tank \\
TBP & Tributyl phosphate \\
TRU & Transuranic \\
TRUEX & Transuranic extraction \\
TWRS & Tank Waste Remediation System \\
WESF & Waste Encapsulation and Storage Facility \\
WHC & Westinghouse Hanford Company \\
WVDP & West Valley Demonstration Project \\
& \\
\hline
\end{tabular}




\section{LIST OF TERMS AND DEFINITIONS (Continued)}

\section{Definitions}

High-level waste: For the purposes of this document, HLW is defined as those aqueous wastes resulting from the operation of the first-cycle solvent extraction system, or equivalent, and the concentrated wastes from subsequent extraction cycles, or equivalent, in a facility for reprocessing irradiated reactor fuels (10 CFR Part 50, Appendix F).

Incidental waste: The term incidental waste originated when the 10 CFR Part 50, Appendix F definition for HLW was promulgated and the Atomic Energy Commission specifically noted that the term HLW did not include "incidental" waste resulting from reprocessing plant operations, such as ion exchange beds, sludges, and contaminated laboratory items, such as clothing, tools, and equipment. Under the same reasoning, the NRC has indicated incidental wastes generated in further treatment of HLW (e.g., salt residues or miscellaneous trash from waste glass processing) would be outside the Appendix F definition.

For application to the Hanford Site wastes, incidental wastes include the miscellaneous wastes resulting from further processing of HLW to enhance the product (e.g., volume reduction) or to remove nonradioactive materials previously added to the HLW (e.g. neutralization of acidic HLW).

Liquid fraction: The low-activity liquid fraction of the tank waste containing a small fraction of water-insoluble solids.

Low-level waste: As specified in the Low-level Radioactive Waste Policy Amendments Act of 1985 (Public Law 99-240), radioactive waste not classified as high-level waste, spent nuclear fuel, or by-product material specified as uranium or thorium tailings and waste.

Low-activity waste: Low-activity waste (LAW) at the Hanford Site is produced by treating the tank wastes. LAW is produced by treating the tank wastes and are "low-level" tank wastes that have not yet received the NRC concurrence as incidental.

Sludge washing: Contacting tank waste sludges with dilute sodium hydroxide solutions to dilute and dissolve aqueous soluble components. Enhanced sludge washing contacts sludges with 3 molar sodium hydroxide solutions to dissolve selected components (aluminum, chromium, phosphorous, and sodium).

Supernatant: The liquid layer above the solids in the waste storage tanks. The liquid supernatant includes drainable interstitial liquids. 
Transuranic waste: As defined and used by the U.S. Department of Energy (DOE Order 5820.2A), radioactive waste that, at the time of assay, contains more than $100 \mathrm{nCi} / \mathrm{g}$ of alpha-emitting isotopes with atornic numbers greater than 92 and half-lives greater than 20 years.

\section{Other notes:}

Units Reported: Throughout the document, all characteristics (i.e., volume, mass, etc.) are reported in metric units except for the radiological units of Sievert (Sv) and Becquerel (Bq). In these two cases, the English units will be used: mrem and curie $(\mathrm{Ci})$, respectively. In some instances, both metric and english units are shown. 


\section{TECHNICAL BASIS FOR CLASSIFICATION \\ OF LOW-ACTIVITY WASTE FRACTION \\ FROM HANFORD SITE TANKS}

\subsection{INTRODUCTION}

National defense activities have generated radioactive waste since 1944 on the Hanford Site in Washington State. Liquid radioactive and chemical wastes from the nuclear material production and research activities were transferred to underground, reinforced-concrete, steel-lined tanks [commonly referred to as single-shell tanks (SSTs) and double-shell tanks (DSTs)] for storage. The U.S. Department of Energy (DOE) and its predecessor organizations (the Manhattan Engineering District, Atomic Energy Commission and Energy Research and Development Administration) discharged waste from reprocessing into SSTs from 1944 to 1971 and into DSTs from 1971 to 1988. Active use of the SSTs ceased in November 1980. Since 1980 , only stabilization and isolation activities have occurred in the SSTs. Plans are to retrieve waste from both single- and double-shell tanks, pretreat the waste as necessary to separate high-level waste (HLW) and low-activity waste (LAW) fractions and immobilize both fractions by vitrification.

This document provides an analysis to support a determination of the radioactive classification of the LAW fraction produced by treating Hanford Site tank wastes. To allow for disposal of the LAW fraction of tank waste near surface, the DOE must receive a determination from the U.S. Nuclear Regulatory Commission (NRC) that the waste is not HLW and, as such, is not subject to NRC licensing.

\subsection{OBJECTIVE}

The objective of this report is to provide a technical basis to support a NRC determination to classify the LAW fraction of Hanford Site tank waste as "incidental" waste.

\subsection{SCOPE}

Based on the current tank waste processing scheme, this document evaluates removal of key radionuclides from the liquid phase of tank wastes to produce a LAW fraction for onsite disposal. Consistent with the revised processing plan for Hanford Site tank wastes (Ecology et al. 1994), the document discusses: (1) the current NRC classification criteria and requirements, (2) the tank waste inventory and radionuclides of interest (i.e., "key" radionuclides), (3) technology options for treating liquids to produce a LAW fraction suitable for onsite disposal and, (4) the technology status and costs for separations processes. 
WHC-SD-WM-TI-699, Rev. 1

This page intentionally left blank. 


\subsection{METHODOLOGY}

This section provides a description of the process for designating a waste as "incidental" and describes the application of the NRC process to the Hanford Site tank waste. Although the NRC does not have licensing authority for the disposal of DOE's low-level waste (LLW), the NRC does have authority for licensing the disposal of HLW for both commercial and defense waste. LAWs are produced by treating the tank wastes and are "low-level" tank wastes that have not yet received the NRC concurrence as incidental. To allow for disposal of the LAW fraction of tank waste near surface, the DOE must receive a determination from the NRC that the waste is not HLW and, as such, is not subject to NRC licensing.

\subsection{WASTE CLASSIFICATION FOR THE HANFORD SITE DOUBLE-SHELL TANK WASTE}

The NRC and the DOE have established a process for determining what defense waste constitutes "incidental" waste. They have applied this process to the Hanford Site DST wastes, Savannah River (South Carolina) wastes and West Valley (New York) tank wastes.

For the Hanford Site tank wastes, the NRC previously concluded that the reprocessing wastes to be disposed in the grout facility (e.g., DST supernatants) would be classified as "incidental" wastes. This classification was based on the processing scheme defined in the Final Environmental Impact Statement for the Disposal of Hanford Defense, High-Level, Transuranic and Tank Wastes, Hanford Site, Richland, Washington; Record of Decision (HDW-EIS) (DOE 1988). Subsequent to this classification, the Hanford Federal Facility Agreement and Consent Order (Tri-Party Agreement) (Ecology et al. 1994) was enacted and the processing scheme for treatment of the tank wastes was modified. The modified processing scheme includes retrieval and processing of single-shell tanks, not to use existing facilities (i.e., B Plant) for tank waste pretreatment, and to dispose of the LAW fraction as glass instead of grout.

The NRC determination for Hanford Site DST wastes was provided in Bernero 1989 and confirmed in 58 FR 12342 (documentation contained in Appendix A). A review of the NRC determination and the subsequent modification of the tank processing scheme is provided in the following section. 


\subsubsection{U.S. Nuclear Regulatory Commission Determination for Hanford Site Double-Shell Tank Waste}

The NRC evaluated and accepted the DOE proposal for pretreatment and disposal of Hanford Site DST wastes (Bernero 1989). The DOE based this proposal on the preferred option from the Environmental Impact Statement for the Disposal of Hanford Defense, Tank, and Transuranic Wastes (HDW-EIS) (DOE 1987). The DOE proposal (Rizzo 1989) is included in Appendix A.

The states of Oregon, Washington, and the Yakama Indian Nation petitioned the NRC to exercise its rulemaking authority and adopt a regulation concerning classification of Hanford Site high-level radioactive wastes currently stored in retrievable, surface, storage facilities (e.g., DSTs). In addition to the rulemaking request, the petitioners requested application of the radionuclide separation criteria on a tank-by-tank basis. In response to the petition, the NRC reviewed their original finding and obtained comments from the public. In 58 FR 12342, the NRC found that DOE's plars for the handling of DST wastes were consistent with their principles of waste decontamination and protection of the public, and denied the rulemaking request.

Figure 2-1 shows a historical timeline on the classification of the LAW fraction from the Hanford Site DST waste. This timeline begins with the completion of the Final Environmental Impact Statement--Disposal of Hanford Defense High Level, Transuranic, and Tank Wastes (HDW-EIS) and ends with the NRC confirmation in 1993 (58 FR 12342). Appendix A contains the correspondence associated with the timeline as well as a synopsis of the correspondence.

\subsubsection{Modification of the Tank Waste Processing Scheme}

Since completion of the original agreement between the NRC and the DOE, several changes have occurred (Wodrich 1994) which impact the tank waste processing scheme. These changes occurred based on a review of the processing scheme with the public and governmental agencies involved in the disposal of tank waste. The primary changes that impact the LAW determination include: (a) planned retrieval of all SST waste; (b) an existing plant will not be used as a pretreatment facility; and (c) a change from grout to glass as a $\mathrm{LLW}$ form.

(a) Since the HDW-EIS (DOE 1987) was issued, the knowledge and the conditions surrounding waste disposal have changed considerably, reversing previous thinking that favored in situ disposal for the SSTs. The emerging tank waste safety issues have raised concernis about long-term stability. Also, the Resource Conservation and Recovery Act of 1976 and the Nuclear Waste Policy Act of 1982 requirements for treatment and geologic disposal of HLW run counter to the in situ disposal approach for SSTs. 
Figure 2-1. Timeline of Classification of Low-Activity Waste Fraction in Hanford Site Tanks.
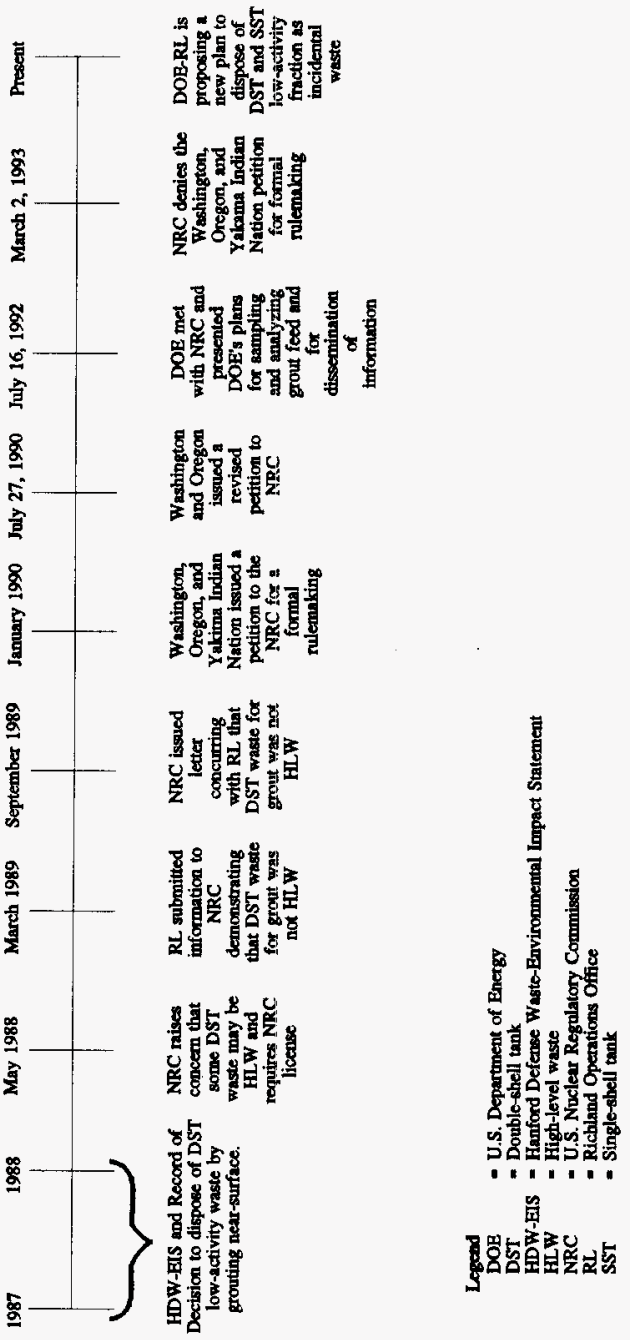
As a result, it is now planned to retrieve and process all DST and SST waste for disposal. Currently, the SST waste is mostly salt cake or sludge. However, the waste in the SST $\mathbf{s}$ must now be redissolved or made into a liquid slurry, retrieved, transferred, and fed into the pretreatment process system. This change increases by four-fold the overall amount of waste requiring processing and the amount of waste for processing to remove cesium increases from about $20,000 \mathrm{~m}^{3}$ to over $600,000 \mathrm{~m}^{3}$ if all tank waste is processed.

(b) Another primary change was based on a technical evaluation that found the $B$ Plant to be unacceptable for use as a pretreatment facility. It was determined B Plant did not comply with current environmental and safety regulatory criteria (Grygiel et al. 1991). Upgrades to reach compliance are not technically or economically practical. The decision not to use B Plant for pretreatment increases the time for implementing radionuclide separations since new facility construction is required.

(c) Grout, as planned for near-surface disposal, was included in the HDW-EIS Record of Decision (DOE 1988). However, stakeholders were concerned about the performance of grout for immobilizing LAW over a long period of time (leachability) and life-cycle cost estimates for other LAW forms being no greater than grout. Other factors such as radionuclide content, lack of retrievability, and the large volume of grout, added to stakeholder concerns about continuing with grout.

To accommodate these changes, the DOE initiated a program rebaselining activity to re-evaluate and plan a revised approach to disposal of the Hanford Site tank waste. The elimination of B Plant as a potential facility for development of pretreatment separations technology, as well as for future pretreatment operations, made the 1989 Tri-Party Agreement milestones difficult to accomplish on schedule.

In December 1991, the Secretary of Energy directed that an integrated Tank Waste Remediation System (TWRS) Program be established to plan and implement the disposal of the tank waste at the Hanford Site. A rebaselined TWRS Program mission, based on a proposed new technical strategy, was provided by DOE in March 1993 to the other two parties of the Tri-Party Agreement in the form of a request to modify the agreement. The tri-parties modified the agreement and signed the fourth amendment to the Tri-Party Agreement (Ecology et al. 1994).

The current fiscal year (FY) 1996 planning calls for a two-phase approach to waste processing (Bader 1995). In 1995, the waste treatment and immobilization acquisition strategy was changed to privatize these functions. This strategy would utilize private contractor(s) to design, build, operate and finance the facilities with DOE paying a fixed price for immobilized waste products delivered to DOE's specification. The plan calls for a proof-of-concept/commercial demonstration-scale effort (referred to as Phase I) to provide confidence in technology, funding methodology, and regulatory strategies to allow financing of a privatization contractor in the next phase. Following Phase I, the plan calls for a full- 
scale production phase (referred to as Phase II). In Phase I and Phase II, DOE will be purchasing services from a contractor-owned, contractor-operated facility under a fixed-price type of contract. It should be noted that the contractor(s) for Phase I and II of the TWRS privatization strategy may select radionuclide removal technologies and/or a LAW form different than presented in this document.

\subsection{NUCLEAR REGULATORY COMMISSION WASTE CLASSIFICATION}

A clear distinction between HLW and LLW does not exist. High-level waste has a source based definition while LLW is generally defined by what it is not (e.g., HLW). The NRC classification of Hanford Site tank wastes is defined by the Low-Level Radioactive Waste Policy Act and the definitions for HLW and "incidental" waste in 10 CFR Part 50, Appendix F.

\subsubsection{Definition of Low-Level Waste}

The current definition of LLW for both the NRC (10 CFR Part 61) and DOE (DOE Order 5820.2A) comes from the Low-Level Radioactive Waste Policy Act. The definition designates LLW as radioactive waste that is not classified as HLW, transuranic (TRU) waste, or nuclear fuel or byproduct material as defined in 11e.(2) of the Atomic Energy Act of 1954 (uranium and thorium tailings and waste). Thus, to determine whether a waste is LLW it must not meet the characteristics of the waste types listed.

The NRC places concentration restrictions on the disposal of waste near surface. Concentration limits for disposal of commercial LLW (which must be in a solid form) are specified in 10 CFR Part 61.55, Waste Classification Requirements for Land Disposal Facilities. The NRC issued an Advance Notice of Proposed Rulemaking (ANPR) for a concentration based Definition of "High-Level Radioactive Waste," 52 FR 5992. Under this ANPR, a waste having concentrations less than either of those found in Table 1 or Table 2 from 10 CFR Part 61 would constitute LLW. Public and agency comment on this ANPR led to recision of the proposal as documented in 53 FR 17709.

The release of radionuclides to the environment is addressed in 10 CFR Part 61.41, which requires that the disposal action does not exceed a $250 \mu \mathrm{Sv}$ per year $(25 \mathrm{mrem} / \mathrm{yr})$ dose from all pathways.

The DOE does not place quantitative concentration restrictions on the disposal of LLW, but requires completion of a performance assessment of the waste disposal activity per DOE Order 5820.2A. The performance assessment must show that the disposal action provides adequate protection to the groundwater per 40 CFR Part 141. Complying with this requirement mandates that the disposal action does not exceed a $40 \mu \mathrm{Sv}$ per year $(4 \mathrm{mrem} / \mathrm{yr}$ ) dose from the groundwater pathway. 


\subsubsection{Definition of High-Level Waste}

Appendix F of 10 CFR Part 50 codified what the Atomic Energy Commission deemed HLW in 1970. For defense waste, the NRC utilizes this definition which was in place when they were given jurisdiction for its long term storage in 1974. This definition consists of a source based definition for HLW. HLW is defined as "those aqueous wastes resulting from the operation of the first-cycle solvent extraction system or equivalent, and the concentrated waste from subsequent extraction cycles, or equivalent, in a facility for reprocessing irradiated reactor fuels."

Another definition of HLW is contained in the 1987 amendment to the Nuclear Waste Policy Act of 1982 (NWPA). The NWPA defines HLW in the following two parts:

1. "The highly radioactive material resulting from the reprocessing of spent nuclear fuel, including liquid waste produced directly in reprocessing and any solid material derived from such liquid waste that contains fission products in sufficient concentration; and

2. Other highly radioactive material that the Commission, consistent with existing law, determines by rule requires permanent isolation."

In context of the NWPA, "requires permanent isolation" means disposal in geologic repository or alternative system with equivalent waste-isolation capabilities.

\subsubsection{U.S. Nuclear Regulatory Commission Guidelines for Classification of Hanford Site Wastes}

The NRC position for Hanford Site wastes was given by Bernero (1989). "At Hanford, the question of waste classification (and NRC licensing authority) has been complicated by the mixing of waste from various sources over the past 45 years. This mixing has changed the original characteristics of the wastes and has resulted, in some cases, in the mixing of HLW and low-level waste (LLW). Consequently, it is now difficult to directly differentiate between HLW and LLW, using the source-based definition of 10 CFR Part 50, Appendix F."

The rulemaking record for Appendix F specifically recognizes a number of "incidental," non-HLW waste streams associated with reprocessing plant operations. These include cladding hulls, ion exchange media, sludges and miscellaneous trash generated during reprocessing operations. Not mentioned, however, are wastes resulting from further processing of HLW (e.g., volume reduction) or removing non-radioactive materials that were added to the HLW for improved processing and/or storage (e.g., the addition of alkaline material to neutralize acidic HLW). At West Valley and the Savannah River Plant, NRC has agreed that such wastes are not HLW. 
The current NRC classification for Hanford Site DST wastes was confirmed in 58 FR 12342. In this determination, the NRC concluded that DOE's proposed processing scheme would remove the largest practical amount of the total site activity, attributable to HLW, for disposal in a deep geologic repository, and the remainder of the waste would be considered "incidental" waste and could be disposed of onsite.

The Commissions's conclusion that the reprocessed DST wastes would be "incidental" wastes was based on DOE's assurances that they have met the following guidelines (Bernero 1993):

1. The waste has been processed (or will be further processed) to remove key radionuclides to the maximum extent that is technically and economically practical.

2. The waste will be incorporated in a solid physical form at a concentration that does not exceed the applicable concentration limits for Class C LLW as set out in 10 CFR Part 61.

3. The waste will be managed, pursuant to the Atomic Energy Act, so that safety requirements comparable to the performance objectives set out in 10 CFR Part 61 are satisfied.

Figure 2-2 depicts these steps as actions and decisions in the form of a logic diagram.

\subsection{INTERPRETATION OF U.S. NUCLEAR REGULATORY COMMISSION GUIDELINES}

The first NRC guideline outlined in Section 2.2.3 uses the criteria "technically and economically practical." Technically and economically practical, as applied to this study, is defined below. NRC guidelines for meeting the concentration limits for Class C LLW and performance objective requirements as set out in 10 CFR Part 61 are well-defined and not as subject to interpretation as the criteria for "technically and economically practical." The application of these guidelines to evaluate specific radionuclide separation processes is provided in Chapter 3.0.

\subsubsection{Definition of Technically Practical and Economically Practical}

Technically practical radionuclide removal technology is defined herein as a technology or process option having plant scale experience or a high probability for successful operation. High probability of success is ensured through laboratory testing on actual tank wastes, applications in like or similar missions, and an engineering judgement of the difficulty to scale a process option for full-size application (e.g., complexity of operation). 


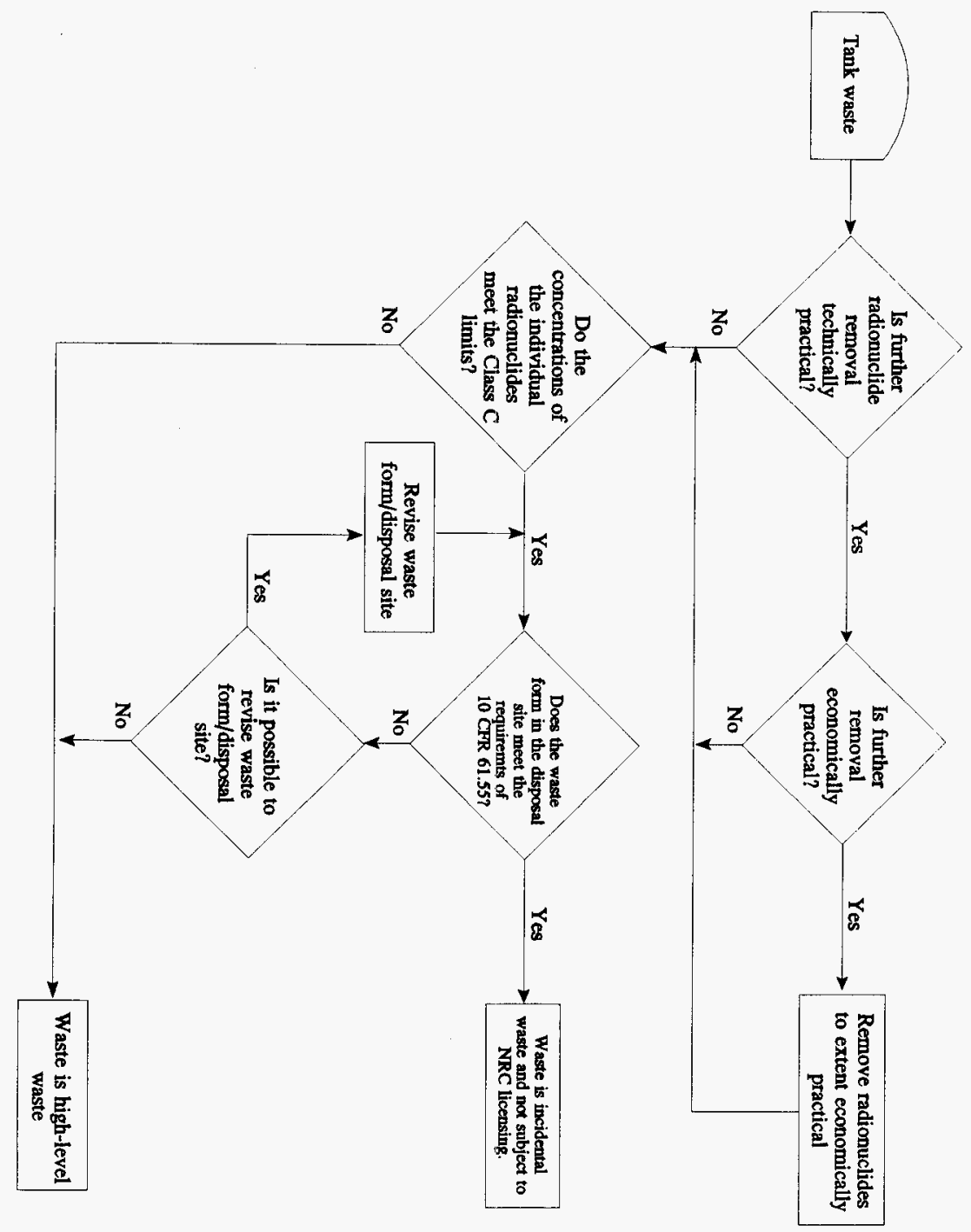

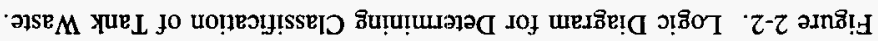


Economic practicality is determined by the total life-cycle cost and the cost per curie removed. The economically practical limit is selected for this evaluation as the point where additional removal costs increase significantly. An economic assessment is not provided if a technology option is considered to be "not technically practical."

\subsubsection{CFR Part 61 Class C Concentration Limits}

The second NRC guideline for classification of the LAW fraction as "incidental" waste is to incorporate the waste in a solid physical form at a concentration that does not exceed the applicable concentration limits for Class C LLW as set out in 10 CFR Part 61.55.

\subsubsection{CFR Part 61 Disposal Performance Objectives}

The third NRC guideline for classification of the LAW fraction as "incidental" waste is to manage the waste so that safety requirements for disposal performance are comparable to the performance objectives of $10 \mathrm{CFR}$ Part 61 (less than $25 \mathrm{mrem} / \mathrm{yr}$ by all pathways). Defense wastes are managed and disposed under guidance from DOE $5820.2 \mathrm{~A}$, which also requires less than $25 \mathrm{mrem} / \mathrm{yr}$ by all pathways and compliance with 40 CFR Part 141 (less than $4 \mathrm{mrem} / \mathrm{yr}$ exposure from groundwater). The DOE order also requires that a Performance Assessment (PA) be prepared for the disposal system. A PA for LAW disposal has not yet been prepared.

A study of disposal system design feature impacts on LAW disposal system performance (Mann et al. 1995) indicates that some ${ }^{99} \mathrm{Tc}$ and ${ }^{79} \mathrm{Se}$ removal and/or disposal design features may be required to meet the NRC guideline and DOE requirements. Disposal design features addressed in the study include waste form corrosion rate, waste form dimensions, engineered barriers, modification of water chemistry, chemical retardants, and moisture diverters. When the PA is complete it will identify areas of concern for long-term release of radionuclides to the environment from the disposal system. At that time, mitigating measures, such as additional radionuclide removal and/or disposal system barriers, will be evaluated and incorporated into the treatment and disposal system as needed to meet PA requirements. 


\subsubsection{Radionuclides of Interest}

The radionuclides of interest in meeting the NRC guidelines for classification of the LAW fraction as "incidental" waste are shown in Table 2-1. These radionuclides are of interest because they represent 99.9 percent of the inventory or are specifically identified in 10 CFR Part 61 (Tables 1 and 2). The radionuclides of interest for the disposal system performance are also shown in Table 2-1. Table 2-1 includes the top five radionuclides for intruder consequences and the top 5 radionuclides based on dose consequences from a drinking water scenario which includes the effect of soil retardation (Schmittroth et al. 1995). An interim performance assessment is in progress and the radionuclides listed are being evaluated to determine if consequences exceed dose for a short term intruder scenario (100 $\mathrm{mrem} / \mathrm{yr}$ ) and/or a long term drinking water scenario (4 mrem/yr). To ensure potentially significant isotopes continue to be monitored, the Interim Performance Assessment also includes additional radionuclides other than those listed in Table 2-1. These additional radionuclides are considered unlikely to be significant for the PA and therefore are not key radionuclides for this study.

Table 2-1. Radionuclides of Interest in meeting the U.S. Nuclear Regulatory Commission "Incidental" Waste Guidelines.

\begin{tabular}{|c|c|c|c|}
\hline \multirow{2}{*}{ Radionuclibe } & \multirow{2}{*}{ 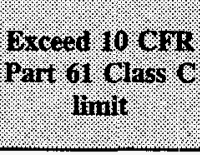 } & \multicolumn{2}{|c|}{ Rotentaily nay excecol disposal } \\
\hline & & moursequerice & Ground water jospo \\
\hline${ }^{137} \mathrm{Cs}$ & 2 tanks & $\mathrm{X}$ & \\
\hline${ }^{90} \mathrm{Sr}$ & & $\mathrm{X}$ & \\
\hline Transuranics & 3 tanks & $X$ & \\
\hline${ }^{99} \mathrm{Tc}$ & & & $\mathrm{X}$ \\
\hline${ }^{3} \mathrm{H}$ & & & \\
\hline${ }^{14} \mathrm{C}$ & & & \\
\hline${ }^{129} \mathrm{I}$ & & & \\
\hline${ }^{126} \mathrm{Sn}$ & & $\mathrm{X}$ & \\
\hline${ }^{79} \mathrm{Se}$ & & & $\mathrm{X}$ \\
\hline $\begin{array}{l}\text { Uranium Isotopes }\left({ }^{233} \mathrm{U} \text {, }\right. \\
\left.{ }^{235} \mathrm{U},{ }^{238} \mathrm{U}\right)\end{array}$ & & & $\mathrm{X}$ \\
\hline
\end{tabular}

${ }^{* 63} \mathrm{Ni},{ }^{60} \mathrm{Co}$, and ${ }^{94} \mathrm{Nb}$ are listed in 10 CFR Part 61 but are not included as key radionuclides. Due to the small inventory of these radionuclides, no significant contribution is made that would affect the determination of the waste classification. 


\subsection{SOURCE OF TANK WASTE}

The Hanford Site tank wastes were produced through the years 1944 to 1988 by reprocessing irradiated nuclear fuel (containing $98,100 \mathrm{Mg}$ of uranium). The aqueous wastes produced were accumulated in 177 underground storage tanks. During this period, these wastes were treated to reduce the stored volume and to remove a portion of the radionuclides. Figure 3-1 depicts the estimated total curie inventory that has been added to the tanks and the number of curies remaining in the tanks (DOE 1994a).

The existing liquid fraction, dissolved salt cake and liquids from treatment of sludges/solids are the candidates for disposal as LAW. Salt cake, generated as a result of supernatant concentration, contains almost none of the soluble radionuclides. Residual interstitial liquor in the salt contains a relatively high cesium concentration but the total volume is small. Therefore, the existing liquid waste fraction contains the overwhelming inventory of the soluble radionuclide inventory.

The solid fraction (sludge) and those radioisotopes separated from the liquid fraction will be vitrified as HLW and disposed in a geologic repository. The insoluble solids (sludges) contain the bulk of the ${ }^{90} \mathrm{Sr}$, TRU, and a small amount of ${ }^{137} \mathrm{Cs}$. The predominant radionuclide in the liquid is ${ }^{137} \mathrm{Cs}$ with a small amount of ${ }^{90} \mathrm{Sr}$ and lesser fractions of TRU, ${ }^{99} \mathrm{Tc},{ }^{3} \mathrm{H},{ }^{14} \mathrm{C},{ }^{79} \mathrm{Se}$, and ${ }^{129} \mathrm{I}$. The cesium and strontium previously removed from the waste are presently stored in capsules and are not currently considered to be waste. Capsules, should they be considered waste, will be disposed as HLW in the geologic repository.

\subsection{TANK WASTE INVENTORY FOR PRETREATMENT}

Table 3-1 presents the total inventory of radionuclides that will be processed by pretreatment and are the values used to assess radionuclide removal requirements in Section 4.0. The tank waste inventory represents the amount of waste and contained radionuclides that will be processed by pretreatment and LAW and HLW vitrification. The TWRS processing inventory consists of the current tank inventory (Orme 1995) and future additions less the tank heel following waste retrieval. Appendix $\mathrm{C}$ provides additional information and references for the source of the tank waste inventory values. 
Figure 3-1. Estimated Hanford Site Tank Waste Radionuclide Inventory. ${ }^{c, d}$

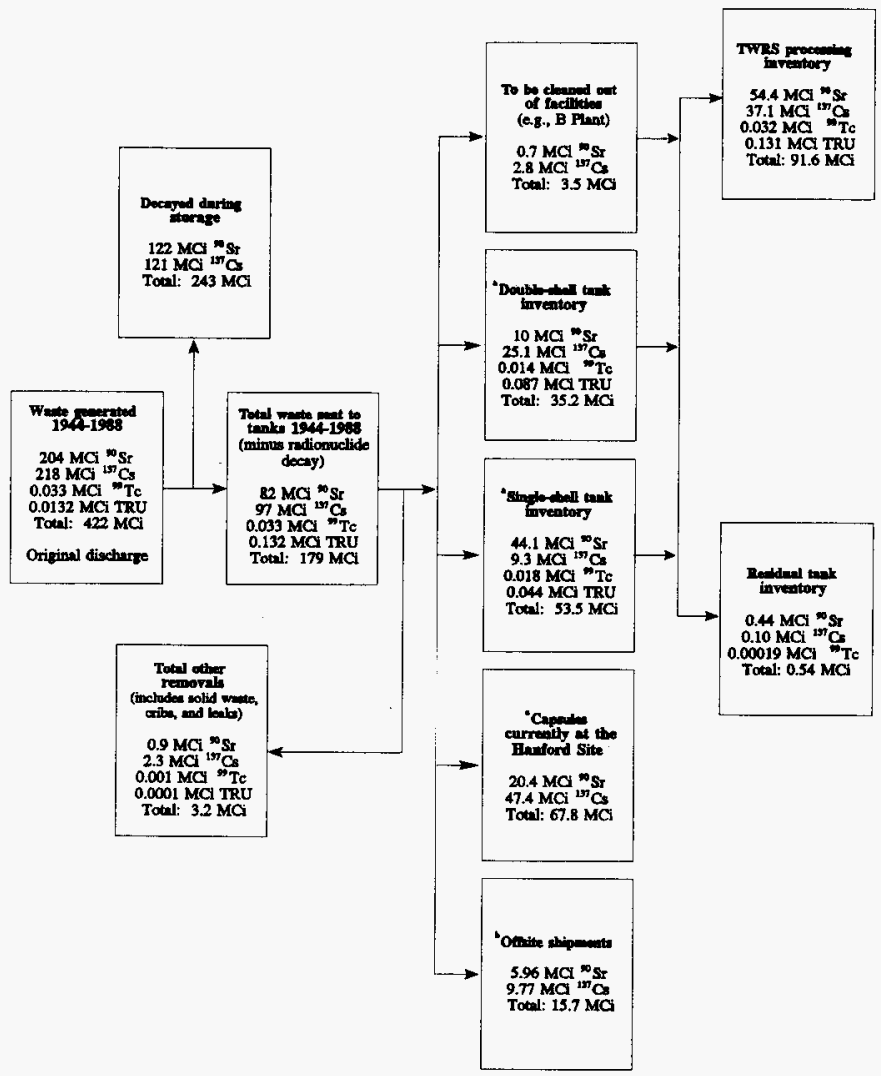

${ }^{a}$ Curie values are based on the Integrated Data Base Report-1994, Rev. 11, Table 2.11 decayed to December 31, 1999.

bThe "offsite shipments" inventory is not expected to return to the Hanford Site for treatment.

${ }^{\mathrm{c}}$ Decay products are not listed. Some radionuclides, such as ${ }^{137} \mathrm{Cs}$ and ${ }^{90} \mathrm{Sr}$, have daughters with relatively short half-lives and are present in concentrations associated with the normal decay chain of the radionuclide.

${ }^{\mathrm{d}}$ Inventories of other key radionuclides (i.e., ${ }^{3} \mathrm{H},{ }^{129} \mathrm{I},{ }^{14} \mathrm{C},{ }^{79} \mathrm{Se}$, uranium isotopes, and ${ }^{126} \mathrm{Sn}$ ) are not shown on the material balance. These radionuclides have small inventories that do not significantly affect the total curies in the material balance. 
Table 3-1. Tank Waste Remediation System Processing Inventory (December 31, 1999, Decay Date).

\begin{tabular}{|c|c|c|c|}
\hline \multirow[t]{2}{*}{ Radionudide } & \multicolumn{3}{|c|}{ Wank Waste Remediaton System Processing } \\
\hline & Soluble & Moritible & Gotal \\
\hline${ }^{137} \mathrm{Cs}$ & 34.1 & 3.01 & 37.1 \\
\hline${ }^{90} \mathrm{Sr}$ & 1.89 & 52.5 & 54.4 \\
\hline Transuranics & 0.00961 & 0.121 & 0.131 \\
\hline${ }^{99} \mathrm{Tc}$ & 0.0228 & 0.0093 & 0.032 \\
\hline${ }^{79} \mathrm{Se}$ & 0.00103 & - & 0.00103 \\
\hline${ }^{14} \mathrm{C}$ & 0.0053 & - & 0.0053 \\
\hline$\overline{129} \mathrm{I}$ & 0.0010051 & - & 0.000051 \\
\hline${ }^{3} \mathrm{H}$ & 0.01 & - & 0.01 \\
\hline${ }^{126} \mathrm{Sn}$ & - & 0.0016 & 0.0016 \\
\hline Uranium & 0.00006 & 0.00094 & 0.001 \\
\hline Total & 36.0 & 55.6 & $91.6^{b}$ \\
\hline
\end{tabular}

${ }^{a}$ The inventories of ${ }^{3} \mathrm{H},{ }^{14} \mathrm{C}$, and ${ }^{129} \mathrm{I}$ are given in Colby (1994). The inventory for

${ }^{79} \mathrm{Se}$ and uranium is given in Mann et al. (1995). The inventory for ${ }^{126} \mathrm{Sn}$ is given in Schmittroth et al. (1995). The primary source of tank waste inventories are given in Orme (1995) for ${ }^{137} \mathrm{Cs},{ }^{90} \mathrm{Sr}$, and TRU because additional detail is given for fractions of soluble and insoluble radionuclides. The values for ${ }^{137} \mathrm{Cs},{ }^{90} \mathrm{Sr}$, and TRU are consistent with the Integrated Data Base Report-1994. See Appendix C for source of TWRS processing inventory.

${ }^{b}$ Round-off error can result in $\pm 0.2 \mathrm{MCi}$.

\subsection{INVENTORY UNCERTAINTIES}

The inventories provided for evaluation of additional radionuclide removal are subject to uncertainties. A general discussion of known or anticipated limitations of the inventory values is given below. Resolution of inventory uncertainties is currently being addressed in Kupfer et al. 1995, draft only.

Cesium and Strontium Inventory: The reported inventories for ${ }^{137} \mathrm{Cs}$ and ${ }^{90} \mathrm{Sr}$ are expected to have small uncertainties (less than 10 percert).

Transuranics (includes ${ }^{239} \mathrm{Pu},{ }^{240} \mathrm{Pu},{ }^{241} \mathrm{Am}$ and ${ }^{237} \mathrm{~Np}$ ): The inventory uncertainty for the transuranics is primarily associated with the quantities in the insoluble fraction. This uncertainty does not affect an analysis of removal from the soluble fraction. The tank waste processing inventory of transuranics used for this analysis is consistent with the Integrated Data Base Report, Rev. 11. 
Technetium Inventory: The ${ }^{99} \mathrm{Tc}$ inventories are based on the assumption of no removal of ${ }^{99} \mathrm{Tc}$ by previous processing. Previous technetium removals include cribbing as supernatants from the tanks, cribbing of process wastes during B Plant strontium and cesium recovery campaigns, ${ }^{99} \mathrm{Tc}$ recovery demonstration and shipment offsite, and removal from the Hanford Site as a contaminant in shipments of uranium oxide product. These previous removals may reduce the ${ }^{99} \mathrm{Tc}$ tank inventory by 25 to 50 percent (Colby and Petersen 1995). Analysis of the ${ }^{99} \mathrm{Tc}$ inventory is ongoing.

Selenium Inventory: The ${ }^{79} \mathrm{Se}$ inventories assume no removal of ${ }^{79} \mathrm{Se}$ by previous processing. Previous selenium removals include cribbing as supernatants from the tanks, and cribbing of process wastes during B Plant strontium and cesium recovery campaigns. These previous removals may reduce the ${ }^{79} \mathrm{Se}$ tank inventory by up to a factor of 2 . Analysis of previous ${ }^{79} \mathrm{Se}$ removals is in progress.

Carbon Inventory: Because of the poorly known chemistry of ${ }^{14} \mathrm{C}$ in the fuel reprocessing operations that generated the Hanford Site tank wastes, the assumed inventory is conservative and the actual inventory may be a factor of 10 lower.

Iodine Inventory: Because of the poorly known removal of ${ }^{129} \mathrm{I}$ in the fuel reprocessing operations that generated the Hanford Site tank wastes, the assumed inventory is an upper bounding inventory and the actual inventory may be a factor of 2 to 10 lower.

Tritium Inventory: Tritium $\left({ }^{3} \mathrm{H}\right)$ contained in the tank wastes is estimated to be $10,000 \mathrm{Ci}$ (Colby 1994). Tritium will be discharged, to a state approved disposal site, from the pretreatment and waste vitrification facilities in the process condensates as tritiated water. Analysis of the ${ }^{3} \mathrm{H}$ inventory is ongoing.

Tin Inventory: Some ${ }^{126} \mathrm{Sn}$ is expected to be solubilized in the alkaline solutions, but inventory values have not yet been specified. No significant quantity of ${ }^{126} \mathrm{Sn}$ is expected in the LAW that would affect the waste classification. Therefore, ${ }^{126} \mathrm{Sn}$ is not considered for additional radionuclide removal. For performance assessment studies, some tin to the LAW fraction is assumed to ensure continued consideration of tin for intruder dose consequences.

Uranium Inventory: The reactor discharges of the major uranium isotope, ${ }^{238} \mathrm{U}$, are well established using the ORIGEN2 model. However, the production estimates of higher actinides, including other uranium and plutonium isotopes, is more difficult to calculate. Further analysis is needed to refine the values for ${ }^{234} \mathrm{U},{ }^{236} \mathrm{U}$, and ${ }^{241} \mathrm{Am}$.

Other--Sodium Inventory: The impact of a potential reduction in the tank sodium inventory was not quantitatively determined in this study. Qualitatively, the costs for cesium ion exchange will not change significantly with a reduction in the sodium inventory. Agnew (1995) indicates that the total sodium inventory in the tank wastes may be approximately 60 percent of the current reported values. This would decrease the predicted volume of the immobilized LAW form since sodium is the major constituent in the LAW, but will not affect Class $\mathrm{C}$ concentration limits. 


\subsection{RADIONUCLIDE SEPARATIONS TECHNOLOGIES}

The TWRS plans to further pretreat the tank waste by separating the tank wastes into a HLW fraction and a LAW fraction. Pretreatment has the goal of minimizing the volume of HLW while reducing the radionuclide content of the LAW fraction to permit onsite disposal. Pretreatment includes the baseline process of enhanced sludge washing (Orme 1995).

\subsection{BASELINE PRETREATMENT PROCESS}

In this study, the baseline pretreatment process for evaluation of incremental separations of Hanford Site tank wastes includes the following:

- Previously separated radionuclides

- Solids/liquids separations, which includes enhanced (caustic) sludge washing.

The baseline pretreatment process removes an estimated total of $137.7 \mathrm{MCi}$ of radionuclides from the TWRS processing inventory for offsite geologic disposal. The baseline separation includes $77.8 \mathrm{MCi}$ of radionuclides that were originally separated and encapsulated (total original inventory), $6.38 \mathrm{MCi}$ (HAPO shipments) that have been separated by other processing and are already shipped offsite, and $54 \mathrm{MCi}$ of radionuclides (see Table 4-1) that will be separated with the HLW sludges (i.e., solids/liquids separations).

The baseline pretreatment processing results in an estimated total capital, operating, and geologic disposal cost savings of $\$ 9$ billion (Colby 1995) over geologic disposal of all tank wastes (i.e., no solids/liquid separations).

\subsubsection{Solids/Liquids Separations}

The Tank Waste Remediation System (TWRS) process includes the characterizing, retrieving, treating, and disposing of chemicals contained in the SSTs and DSTs. Using simple separation techniques, the retrieved waste is segregated into a low-activity fraction containing the bulk of the non-radioactive constituents, and a high-activity fraction containing most of the solids. The bulk of the ${ }^{90} \mathrm{Sr}$ and TRU radionuclides are contained in the water insoluble fraction (i.e., solids) of the tank wastes. The bulk of the ${ }^{137} \mathrm{Cs},{ }^{99} \mathrm{Tc}$, and essentially all of the ${ }^{79} \mathrm{Se},{ }^{129} \mathrm{I},{ }^{14} \mathrm{C}$, and ${ }^{3} \mathrm{H}$ are contained in the soluble fraction of the tank wastes. The ${ }^{79} \mathrm{Se}$, ${ }^{129} \mathrm{I},{ }^{14} \mathrm{C}$, and ${ }^{3} \mathrm{H}$ are $\leq 0.01 \mathrm{MCi}$ in the soluble fraction and essentially none exists in the insoluble phase. The processing inventory of radionuclides in the insoluble and soluble fractions was shown in Table 3-1. The insoluble fraction contains 55.6 of the $91.6 \mathrm{MCi}$ projected to be in the tanks.

From the process flowsheet, batches of waste are retrieved into sludge wash tanks. Retrieved solids are washed four times using enough caustic (i.e., sodium hydroxide) to arrive at 3 molar $\mathrm{NaOH}$ solution and $8 \mathrm{wt} \%$ solids slurry in the product stream from caustic 
washing. The caustic wash will solubilize additional amounts of aluminum, chromium, phosphate and sodium from the solids. Each wash is preceded by settling and decanting to remove liquids and concentrate the solids. Batches of leached and washed solids are combined and blended while the decanted liquids are combined for additional treatment.

The amount of radionuclides removed with liquid fraction is based on a solids carryover of 0.33 percent of the solids in the tank for each of three decants (Orme 1995). This results in an overall solids carryover of 1 percent for design purposes. To account for operational inefficiencies and uncertainties in solids/liquid separations, a more conservative solids carryover of 3 percent is applied for this evaluation. No further removal is provided for the 3 percent solids carryover. The liquids/solids separations process also assumes that the inefficiencies in washing interstitial supernatant from the solids results in carryover of 0.135 percent of the soluble radionuclides into the solids phase (Orme 1995).

The total of both inefficiencies during the solids/liquids separation process is shown in Table 4-1 and results in approximately $54 \mathrm{MCi}$ in the solids slurry and $36 \mathrm{MCi}$ in the liquid phase, with an additional $1.7 \mathrm{MCi}$ entrained solids from an assumed 3 percent solids carryover. The $36 \mathrm{MCi}$ in the separated liquids is considered for additional radionuclide separations in Section 4.2. No further separation is assumed for the $1.7 \mathrm{MCi}$ entrained solids.

Table 4-1. Inventory For Additional Radionuclide Removals (MCi Decayed to December 31, 1999).

\begin{tabular}{|c|c|c|c|c|}
\hline \multirow{2}{*}{ Radionuelide } & \multirow{2}{*}{ 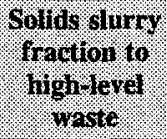 } & \multicolumn{2}{|c|}{ Whilid mation } & \multirow{2}{*}{ Trofal } \\
\hline & & Soluble & $\begin{array}{l}\text { Tntrained } \\
\text { solids }\end{array}$ & \\
\hline${ }^{137} \mathrm{Cs}$ & 2.9 & 34.1 & 0.09 & 37.1 \\
\hline${ }^{90} \mathrm{Sr}$ & 50.9 & 1.89 & 1.57 & 54.4 \\
\hline Transuranics & 0.117 & 0.0096 & 0.004 & 0.131 \\
\hline${ }^{99} \mathrm{Tc}$ & 0.0093 & 0.0228 & - & 0.032 \\
\hline${ }^{79} \mathrm{Se}$ & - & 0.00103 & - & 0.00103 \\
\hline${ }^{14} \mathrm{C}$ & - & 0.0053 & - & 0.0053 \\
\hline${ }^{129} \mathrm{I}$ & - & 0.000051 & - & 0.000051 \\
\hline${ }^{3} \mathrm{H}$ & - & 0.01 & - & 0.01 \\
\hline${ }^{126} \mathrm{Sn}$ & - & - & 0.0016 & 0.0016 \\
\hline Uranium & 0.00094 & 0.00006 & - & 0.001 \\
\hline Totals (rounded) & 54 & 36 & 1.7 & 92 \\
\hline
\end{tabular}




\subsection{TECHNOLOGY OPTIONS}

The NRC guidelines outlined in Chapter 2.0 have been used to assess radionuclide removal technologies and evaluate the practicality of achieving higher degrees of separation from the LAW fraction. This section focuses on the technologies for separation of radionuclides from supernatants to produce LAW. This evaluation consists of identifying: (1) individual technology options for radionuclide separations processes, (2) the status of the technology, (3) defining the radionuclide removal efficiency and (4) determining the cost of implementing the technology. The cost of implementing a given technology, with an estimated curie removal for the technology, is assessed in terms of cost per curie to provide a measure of economically practical. An economic assessment is provided only if a technology is considered to be technically practical. ${ }^{2}$

Technology options for radionuclide removal are considered for the radionuclides of interest as defined in Section 2.3.4. The radionuclides discussed in the sections below are ${ }^{137} \mathrm{Cs}$, ${ }^{90} \mathrm{Sr}$, TRU, ${ }^{99} \mathrm{Tc},{ }^{79} \mathrm{Se},{ }^{14} \mathrm{C},{ }^{129} \mathrm{I},{ }^{3} \mathrm{H}$ and uranium isotopes. The technology options for each of the key radionuclides are evaluated and compared using the definitions of technically and economically practical.

\subsubsection{Cesium Removal}

The liquids for pretreatment contain approximately $34.1 \mathrm{MCi}$ cesium for further separations. Technology options considered in this study for removal of soluble cesium from the waste supernatants and wash liquors are: (1) a cesium ion exchange process using column operation, (2) in-tank precipitation or sorption process and, (3) volatilization of cesium from the LAW melter.

Cesium is the key radionuclide requiring additional removal to establish a new LAW limit. Cesium represents approximately 91 percent of the curies in the liquid fraction after solids/liquid separations have been performed. The distribution of cesium concentration in the tank wastes is shown in Figure 4-1. Adding the totals from the first three blocks in Figure 4-1 shows approximately 90 percent of the cesium curies is contained in 21 percent of the total volume.

${ }^{2}$ Cost estimates are based on 1995 dollars. In some cases, cost data were obtained from documents completed before 1995 and data are in 1993 or 1994 dollars. However, the overall costs will not be impacted by a 1 or 2 year cost escalation. 
Figure 4-1. Waste Volume to Curie Content Comparison.

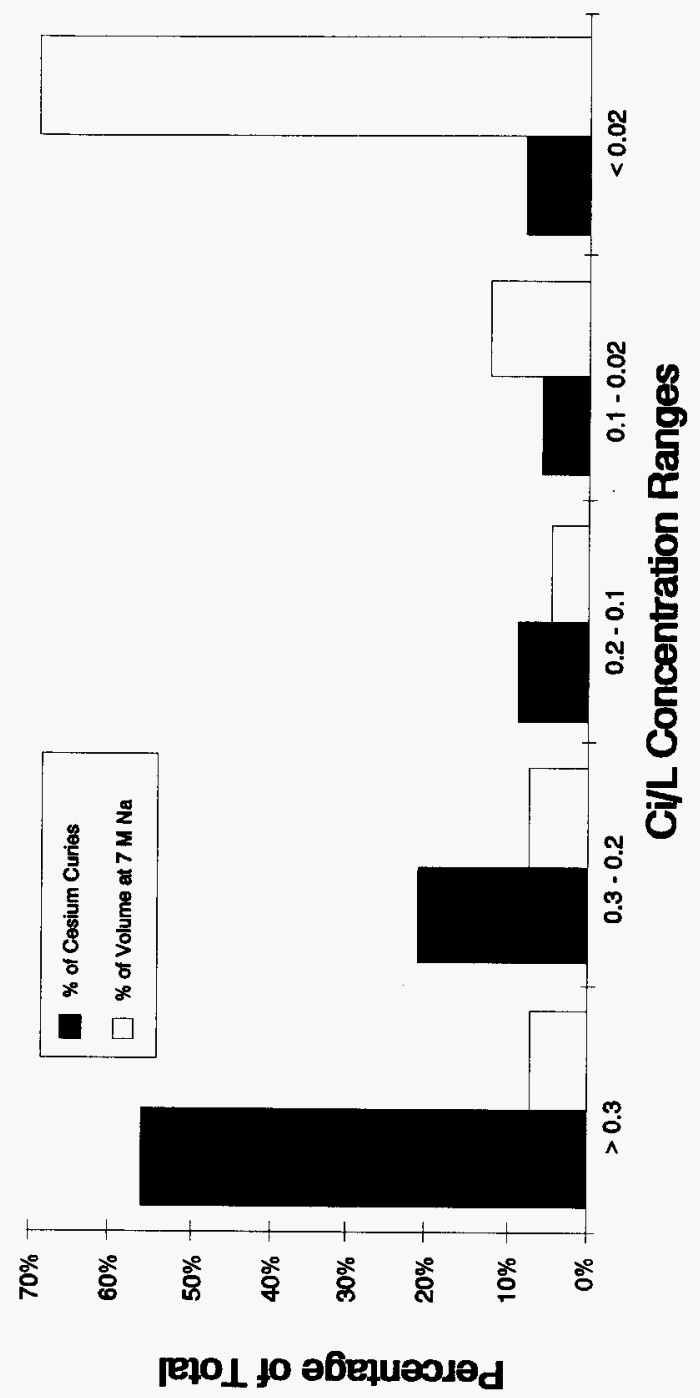


4.2.1.1 Ion Exchange--Column Operation. Cesium can be removed from alkaline solutions high in sodium with cation exchange: resins. Beginning in 1967, cesium was extracted from tank wastes and recovered in B Plant using regenerable ion exchange processing. The use of regenerable cesium ion exchange in B Plant was the basis for radionuclide removal in the NRC determination. Ion-exchange using non-regenerable resins for cesium removal is also considered as a technology option.

The following sections discuss cesium ion exchange processes for single- and two-cycle technology options.

4.2.1.2 Single Cycle of Ion Exchange. The current design basis for evaluation of cesium ion exchange is based on ion exchange resin CS-100 ${ }^{3}$, and the laboratory data generated over several years of testing at Westinghouse Process Chemistry Laboratory and Pacific Northwest National Laboratory. It is an engineering judgement that the properties of CS-100 provide a conservative basis for ion exchange design. Alternate ion exchange materials, e.g., resorcinol formaldehyde, granular potassium cobalt hexacyanoferrate, crystalline silicotitanante (CST) and SuperLig ${ }^{\mathrm{TM}} 644^{4}$, are also being evaluated for cesium removal from alkaline solutions (Lee et al. 1996). Silicotitanates have been used at the West Valley Demonstration Project (WVDP) facility at West Valley, New York for cesium removal from tank wastes. The silicotitanate used at West Valley was in the form of titania doped zeolite in columns.

The cesium ion exchange process in the reference flowsheet (Orme 1995) has a design basis of 99 percent removal of the soluble cesium from supernatants and wash liquors. The experience at B Plant with ion exchange during the cesium recovery campaigns for cesium capsule production was typically 90 percent recovery in order to maximize the total curies removed per unit time and not to minimize the cesium concentration in the treated liquid (Barton et al. 1986). A design basis of 99 percent cesium removal from the clarified supernatants and wash liquors is imposed as technically feasible. The cesium ion exchange process is evaluated based on a 97 percent cesium removal efficiency to allow for resin degradation and design and operational uncertainties.

Technical Practicality of Single-Cycle Ion Exchange. Cesium ion exchange with an organic resin was used at $\mathrm{B}$ Plant to recover the $55 \mathrm{MCi}$ of ${ }^{137} \mathrm{Cs}$ for the encapsulation campaign at the Hanford Site. Removal of cesium using ion exchange technology is considered to be technically practical. Selection of an appropriate ion exchange material continues to be developed and tested.

\footnotetext{
${ }^{3}$ Duolite CS-100 is a registered trademark of Rohm and Haas, Philadelphia, Pennsylvania.

${ }^{4}$ SuperLig 644 is a polymer resin of the covalently bound SuperLig ${ }^{\mathrm{TM}}$ macrocycle family of sequestering ligands from IBC Advanced Technologies (American Fork, Utah).
} 
Cost of Single-Cycle Ion Exchange. The cost for cesium removal by ion exchange is based on data in the TWRS Environmental Impact Study (EIS) data package (Slaathaug 1995, Table F-36). The capital cost for cesium ion exchange is $\$ 380$ million. The total operating cost for the cesium ion exchange system including decontamination and decommissioning (D\&D) costs is $\$ 602$ million to process all the: waste. If all of the soluble waste is treated using a cesium ion exchange process, up to $33.1 \mathrm{MCi}$ ( 97 percent separation efficiency) of ${ }^{137} \mathrm{Cs}$ is removed at a total cost of $\$ 982$ million. This results in an average cost of $\$ 30 / \mathrm{Ci}$ ${ }^{137} \mathrm{Cs}$.

The cost per incremental curie cesium removed is driven primarily by the operational costs of a cesium ion exchange facility. For this evaluation, a tank waste retrieval sequence was optimized to retrieve the tanks with the highest cesium concentration first. Data from the "baseline retrieval sequence" (Certa 1995) were optimized for removal of cesium. The retrieval sequence was prioritized to process only wastes for selected cesium concentrations. Output of the optimized sequence includes the waste volume processed and the resulting $\mathrm{MCi}$ cesium disposed in the LAW (Slaathaug 1996b). From this data, Figure 4-2 plots the \$/Ci cesium removed versus the cesium concentration in the feed. For an optimized retrieval sequence, the operational cost per curie begins to increase significantly at concentrations less than $0.05 \mathrm{Ci}{ }^{137} \mathrm{Cs} / \mathrm{L}$. If a concentration of greater than $0.05 \mathrm{Ci}{ }^{137} \mathrm{Cs} / \mathrm{L}$ is selected as the economically practical limit for terminating cesium removal processing, this results in a total cesium removal of $29 \mathrm{MCi}$ cesium with approximately $5 \mathrm{MCi}$ cesium remaining in the LAW.

Table 4-2. Incremental Operating Cost for Removing Additional Cesium.

\begin{tabular}{|c|c|c|c|c|}
\hline \multirow[b]{2}{*}{ 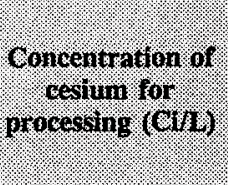 } & \multicolumn{4}{|c|}{ 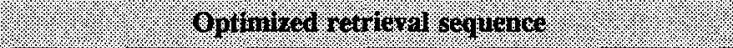 } \\
\hline & Wilhon liners & 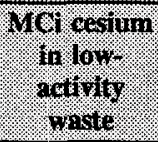 & Total $60 \mathrm{st}$ m & $\begin{array}{l}\text { Imoromental } \\
\text { operaing gost }\end{array}$ \\
\hline$<0.01$ & $420.9^{*}$ & 1.0 & 982 & 147 \\
\hline 0.01 & 255.7 & 1.9 & 850 & 59 \\
\hline 0.02 & 130.5 & 3.6 & 749 & 28 \\
\hline 0.05 & 88.7 & 4.8 & 715 & 11 \\
\hline 0.1 & 78.1 & 5.6 & 706 & 5 \\
\hline 0.2 & 59.6 & 8.6 & 691 & 3 \\
\hline 0.3 & 29.6 & 15.7 & 667 & 2 \\
\hline 0.5 & 6.5 & 23.6 & 648 & 0.5 \\
\hline
\end{tabular}

*Total volume of decanted tank liquids, adjusted to $7 M$ sodium, no wash solutions included. 
Figure 4-2. Cost per Curie Cesium Recovered versus Cesium Concentration in the Feed.

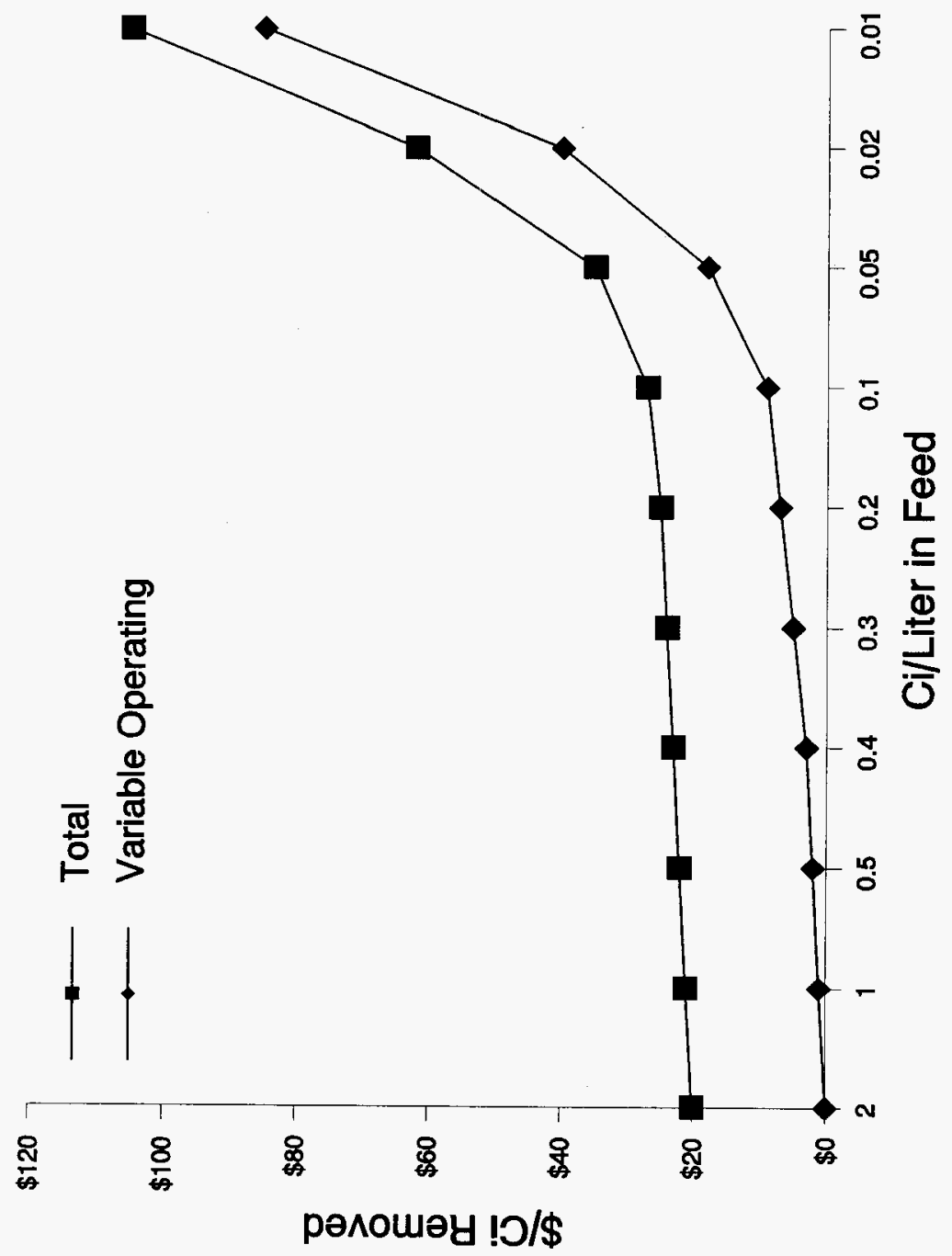


4.2.1.3 Second Cycle of Cesium Ion Exchange. A second cycle of cesium ion exchange treats the raffinate from the first ion exchange cycle and removes an additional $1.0 \mathrm{MCi}$ ${ }^{137} \mathrm{Cs}$ assuming 97 percent recovery in the second cycle. This results in a total recovery of 99.9 percent for two cycles of cesium ion exchange and separates approximately $34 \mathrm{MCi}$ cesium.

Technical Practicality of Second-Cycle Ion Exchange. The technical practicality of a second cycle of cesium ion exchange is similar to a single cycle of ion exchange.

Cost of Second-Cycle Ion Exchange. The costs associated with a second cycle of cesium ion exchange are derived from the difference in costs for separations facilities containing two cycle and one cycle of cesium ion exchange developed in the Facility Configuration Report (Boomer et al. 1993) (see Appendix B). The difference in capital costs attributed to the second cycle is $\$ 275$ million. The operating cost differences for the second cycle of cesium ion exchange are $\$ 47$ million for materials, $\$ 15$ million for equipment replacement, and $\$ 83$ million for $\mathrm{D} \& \mathrm{D}$ costs. If all soluble waste is treated, the additional $1 \mathrm{MCi}$ of ${ }^{137} \mathrm{Cs}$ is separated for a cost of $\$ 420$ million. This results in a cost of $\$ 420 / \mathrm{Ci}{ }^{137} \mathrm{Cs}$.

4.2.1.4 Cesium Precipitation In-Tank for All Wastes. Several materials have been proposed for removal of cesium from alkaline Hanford Site wastes by precipitation or sorption. These include nickel ferrocyanide, tetraphenyl borate and silicotitanates.

Sodium ferrocyanide and nickel sulfate were used at Hanford Site to remove cesium from SST supernatants. Concerns with (1) potential safety problems (nitrate-cyanide mixtures in the tanks), (2) a requirement to add acid to the wastes for $\mathrm{pH}$ adjustment before precipitation, and (3) process sensitivity to $\mathrm{pH}$ control have eliminated sodium ferrocyanide from consideration of full scale application for Hanford Site wastes.

The in-tank precipitation of cesium by the addition of tetraphenyl borate is used at the Savannah River Site (SRS) for treatment of tank wastes. Tetraphenylborate co-precipitates potassium with the cesium. Hanford Site wastes are different from the SRS wastes because Hanford Site wastes contain significant quantities of potassium. Hanford Site wastes contain $737 \mathrm{Mg}$ of potassium, which would result in $6,750 \mathrm{Mg}$ or 70 million L (18 Mgal) (d'Entremont and Walker 1987) of precipitate. The excessive quantity of chemical consumption and quantities of metal-organic precipitates to store and process through HLW vitrification have eliminated tetraphenyl borate from consideration.

Subsequent to the West Valley application of silicotitanates, research has evolved silicotitanates into a more selective material, CST. The CST materials have been developed by Sandia National Laboratories in conjunction with Texas A\&M University and UOP Molecular Sieves as an alternative to organic ion exchange resins for cesium removal from Hanford Site tank wastes. The CST material has been manufactured into a suitable engineered form and is commercially available. If obtained in bulk quantities, CST may offer an increased ion exchange capacity, eliminate safety concerns regarding organic resin degradation, and reduce secondary waste generation compared to the use of organic resins. 
CST is not regenerable. Therefore, the CST material cannot be eluted and must be disposed in a loaded form.

An evaluation of how the use of CSTs would impact HLW glass production was performed by Swenson (1995). The reference evaluated removal of ${ }^{137} \mathrm{Cs}$ to produce $1 \mathrm{Ci}{ }^{137} \mathrm{Cs} / \mathrm{m}^{3}$ in the LAW and concludes that there is no benefit to in-tank Cs removal using CSTs. CST material contains $\mathrm{TiO}_{2}$ which is predicted to have a low solubility in the HLW glass product (1wt\%). This results in a maximum usage of approximately $230 \mathrm{MT}$ of $\mathrm{TiO}_{2}$ before the $1 \mathrm{wt} \% \mathrm{TiO}_{2}$ is exceeded. Because of the large quantity of CST material required for an in-tank process for all waste, there is a significant increase of the HLW glass production whether by single-batch $(14,303,900 \mathrm{MT}$ at 1 percent titania) or column contacting (70,000 MT at 1 percent titania) of the CST with the waste. The current TWRS flowsheet (Orme 1995) projects 22,800 MT of HLW glass.

Technical Practicality of Cesium Precipitation In-Tank for All Wastes. Cesium precipitation in-tank for all wastes using CST is not practical due to the quantity of CST material required to remove greater than 99 percent of the cesium.

Cost of Cesium Precipitation In-Tank for All Wastes. No economic analysis is provided since the technology is not practical.

4.2.1.4.1 In-Tank Precipitation for Selected Wastes. Selective treatment of tank wastes is also an option for CST. Treating only the tank wastes more concentrated in cesium can significantly reduce CST usage and HLW volume. The selective CST treatment of tank wastes more concentrated in cesium can maximize the total cesium removed by a fixed amount of CST and the contained $\mathrm{TiO}_{2}$. The HLW canisters $\left(1.26 \mathrm{~m}^{3}\right.$ glass per canister is assumed for this report) produced are a function of the total titania contained in the CST used to treat all wastes. The quantity of CST used to treat the liquid phase of tank wastes is proportional to the volume of waste, degree of desired cesium removal [Decontamination Factor (DF)], and the method of supernatant/CST contact.

The selective CST treatment of tank wastes is based on maximizing the total cesium removed by a fixed amount of CST and the contained $\mathrm{TiO}_{2}$. This optimization assumes that each batch of composite waste produced by the waste retrieval system is treated with a variable amount of CST and variable DF to produce a constant cesium to sodium ratio in the treated supernatants and an approximate constant cesium to $\mathrm{TiO}_{2}$ ratio in the loaded CST.

The projected amount of vitrified HLW allows the addition of titania up to 1 percent. This results in a potential use of $230 \mathrm{MT}$ of titania contained in CST without significant penalty, less than 136 canisters of additional HLW. The concentration of ${ }^{137} \mathrm{Cs}$ in waste tank supernatants also varies significantly between tanks.

An evaluation of selective treatments using CST is provided in Slaathaug 1996a. This study shows a 90 percent cesium removal is achieved with the incremental additions of CST equalling $230 \mathrm{MT} \mathrm{TiO}_{2}$ (note: $230 \mathrm{MT} \mathrm{TiO}_{2}$ is the amount allowable before exceeding the 
$1 \mathrm{wt} \%$ titania solubility limit in $\mathrm{HLW}$ glass): For single batch contacts, an estimated $8 \mathrm{MCi}$

${ }^{137} \mathrm{Cs}$ would remain in the LAW using this technology.

Technical Practicality of In-Tank Precipitation for Selected Wastes. Selective treatment of tank wastes using CST is not technically practical for this analysis due to the development work still required (i.e., in-tank controls and scale-up issues). For this document, it is assumed further development is needed to accurately define the capacity of different forms of CST for application to Hanford Site tank wastes. The reference study (Swenson 1995) recommends additional study to accurately define the capacity of different forms of CST and to increase the allowable concentration of titania in HLW glasses.

Cost of In-Tank Precipitation for Selected Wastes. Since the use of CST for cesium separation is not considered technically practical for this analysis, no economic assessment has been provided. ${ }^{5}$

4.2.1.5 Cesium Volatilization. The volatilization of some cesium during the melting of radioactive waste glasses is intrinsic to the vitrification process. A LAW melter could provide removal of volatile radionuclides from the LAW glass by routing volatile radionuclides captured in the melter offgas scrubber solution to the HLW feed stream instead of recycle to the LAW melter feed.

The melting of HLW glasses typically volatilizes 20 percent of the feed cesium from Joule heated melters. The HLW melters typically operate with a cold cap and a maximum temperature of $1100^{\circ} \mathrm{C}$ to minimize cesium volatility. Operation of a Joule heated LAW melter at temperatures of $1300^{\circ} \mathrm{C}$ or greater and with sparging to disrupt the cold cap could expect to increase cesium volatility up to 50 percent. Tests in FY 1995 (Higley 1995) with hot gas heated melters for LAW vitrification gave indicated cesium volatilities of 50 to 90 percent of the feed cesium.

Technical Practicality of Volatilization. Cesium volatilization and recovery is a design feature for full scale HLW melters. The details of process control needed to maximize and control cesium volatilization have not been established. The removal of cesium from aqueous off-gas treatment requires development and no production scale applications have been performed. Therefore, cesium removal using only a volatilization technology is considered not technically practical.

Cost of Volatilization. No economic analysis is provided since the technology is considered not technically practical.

${ }^{5}$ Appendix B, Cost Estimates, which contains limited cost data for CST that have been recently investigated, is provided for information only. 


\subsubsection{Strontium Removal}

The liquid fraction for further pretreatment contain approximately $3.46 \mathrm{MCi}{ }^{90} \mathrm{Sr}$ (rounded to $3.5 \mathrm{MCi}$ ) for further separations. Of the $3.5 \mathrm{MCi}, 1.89 \mathrm{MCi}$ is soluble ${ }^{90} \mathrm{Sr}$ and $1.57 \mathrm{MCi}$ (rounded to $1.6 \mathrm{MCi}$ ) is insoluble ${ }^{90} \mathrm{Sr}$ from solids carryover. No further removal is provided for the $1.57 \mathrm{MCi}$ insoluble ${ }^{90} \mathrm{Sr}$ (see Section 4.1.1).

Technology options considered in this study for removal of soluble strontium from the waste supernatants and wash liquors are: (1) precipitation by chemical addition, (2) deactivation of the complexants, (3) complexant destruction and, (4) solvent extraction.

An analysis of DST radionuclide removal requirements on a tank-by-tank basis (Schulz 1995) has determined that no additional removal of soluble ${ }^{90} \mathrm{Sr}$ is required for any tank to meet the NRC Class $\mathrm{C}$ criteria. The ${ }^{90} \mathrm{Sr}$ concentration in glasses made from supernatant liquid in at least 21 of the DSTs will contain less than $150 \mathrm{Ci}{ }^{90} \mathrm{Sr} / \mathrm{m}^{3}$ without pretreatment, which is below the Class B limit for ${ }^{90} \mathrm{Sr}$. The highest concentrations of soluble strontium is found in $\mathrm{CC}$ wastes. Precipitation processes discussed for TRU removal result in ${ }^{90} \mathrm{Sr}$ that co-precipitates with the removal of soluble TRU (see Section 4.2.3.3).

The CC supernatant contains multivalent cations of radionuclides such as strontium and transuranics in greater concentrations than normal in alkaline solutions. This increased concentration occurs because of the presence of complexants added during previous strontium and cesium recovery campaigns in B Plant.

4.2.2.1 Precipitation of Strontium Phosphate from All Tank Wastes. Treating all the DST and SST wastes (177 tanks) at $5 \mathrm{M} \mathrm{Na}$ to remove $1.8 \mathrm{MCi}$ of the $1.9 \mathrm{MCi}$ soluble ${ }^{90} \mathrm{Sr}$ would require $50,000 \mathrm{MT}$ of $\mathrm{Sr}\left(\mathrm{NO}_{3}\right)_{2}$ and would increase the number of HLW canisters from 6,800 to 14,200 .

The precipitation of strontium from the complexant bond by the addition of nonradioactive strontium involves isotopic exchange between two dissolved strontium atoms. This reaction may require rapid and intensive mixing before the nonradioactive strontium becomes unavailable for the exchange reaction due to precipitation as hydroxide or phosphate.

Technical Practicality of Strontium Phosphate Precipitation for All Tank Wastes. Precipitation of strontium phosphate has been investigated with limited hot bench scale testing and is considered not technically practical. Treating all the wastes would significantly impact (increase) the amount of HLW glass.

Cost of Strontium Phosphate Precipitation for All Tank Wastes. No economic analysis is provided since the technology is considered not technically practical at this time.

4.2.2.1.1 Precipitation of Strontium Phosphate from Selected Wastes. Recent radionuclide removal tests indicates that ${ }^{90} \mathrm{Sr}$ is effectively removed from $\mathrm{CC}$ waste ( 95 percent removal) by addition of 0.1 molar nonradioactive $\operatorname{Sr}\left(\mathrm{NO}_{3}\right)_{2}$ to precipitate $\mathrm{Sr}_{3}\left(\mathrm{PO}_{4}\right)_{2}$ (Schulz 1995). 
Treatment of selected tanks of CC waste, 241-AN-102, 241-AN-107 and 241-AY-101, would remove $0.54 \mathrm{MCi}$ of the soluble $0.57 \mathrm{MCi}^{90} \mathrm{Sr}$ in three $\mathrm{CC}$ tanks. Treatment of the $10,800 \mathrm{~m}^{3}$ in these three tanks would require the equivalent of $114 \mathrm{Mg}$ of SrO be incorporated into the HLW glass. Assuming a HLW glass waste oxide loading of $45 \mathrm{wt} \%$ and an average SrO concentration of $0.5 \mathrm{wt} \%$ in blended HLW glass, an extra 75 canisters of HLW glass would result.

The precipitation of strontium from the complexant bond by the addition of nonradioactive strontium involves isotopic exchange between two dissolved strontium atoms. This reaction may require rapid and intensive mixing before the nonradioactive strontium becomes unavailable for the exchange reaction due to precipitation as hydroxide or phosphate.

Technical Practicality of Strontium Phosphate Precipitation for Selected Wastes. Precipitation of strontium phosphate has only been investigated with limited hot bench scale testing and is not technically practical.

Cost of Strontium Phosphate Precipitation for Selected Wastes. No economic analysis is provided since the technology is considered not technically practical at this time.

4.2.2.2 Strontium Removal by Complexant Destruction in All Wastes. The complexants that solubilize strontium in an alkaline solution can be destroyed in several minutes by thermal digestion at elevated temperature and pressure. A continuous flow application requires a temperature greater than $200^{\circ} \mathrm{C}$. After destruction of the complexants, the multivalent ions precipitate from the solution and are removed with solids/liquid separations equipment. The separated solids are slurried to DSTs for lag storage and future vitrification as HLW.

Technical Practicality of Complexant Destruction for All Wastes. The development status of complexant destruction by digestion at elevated temperature and pressure has been demonstrated by bench scale testing for commercial nonradioactive applications. No pilot plant testing or production scale processing has been performed on radioactive wastes similar to the Hanford Site tank wastes. Therefore, this process is considered not technically practical due to the required development work.

Cost of Complexant Destruction for All Wastes. No economic analysis is provided since the technology is not technically practical.

4.2.2.2.1 Strontium Removal by Complexant Deactivation for Selected Wastes. The complexants that solubilize strontium in an alkaline solution can be destroyed or deactivated by thermal digestion as discussed in Section 4.2.2.2. Application of thermal digestion for selected wastes can be performed in-tank. An analysis of in-tank heat and digest to deactivate the complexant in CC waste tanks 241-AN-102, 241-AN-107, and 241-AY-101 was performed by Klem (1995). 
Technical Practicality of Complexant Deactivation for Selected Wastes. Testing of the heat and digest process is still in progress. The complexant is decomposed by slow chemical reactions performed by heating the tank contents to $90^{\circ} \mathrm{C}$ to $100{ }^{\circ} \mathrm{C}$ for an extended period of time. The process is predicted to require 4.2 to 14.3 years to perform in-tank at $100^{\circ} \mathrm{C}$ and the final performance is uncertain. Complexant deactivation for strontium removal is considered not technically practical.

Cost of Complexant Deactivation for Selected Wastes. No economic analysis is provided since the technology is considered not technically practical.

4.2.2.3 Strontium Removal by Solvent Extraction in All Wastes. The alkaline solutions that contain strontium are acidified using nitric acid. Strontium is removed from the acidified solution using a solvent extraction system similar to the processes described in the Tank Waste Technical Options Report (Boomer et al. 1993). Strontium recovery by solvent extraction is included with TRU separations. This process, using the solvent developed by Argonne National Laboratory (ANL), is called Strontium Extraction (SREX).

Technical Practicality of Solvent Extraction in All Wastes. Solvent extraction separation of strontium with SREX has been demonstrated in laboratory testing. However, no pilot plant testing or production scale processing using the SREX process has been performed on radioactive wastes similar to the Hanford Site tank wastes. Solvent extraction using other solvents has previously been used in B Plant at Hanford Site to recover strontium. Therefore, solvent extraction for strontium is considered technically practical.

Cost of Solvent Extraction in All Wastes. The cost for strontium removal by solvent extraction is based on facility designs presented in the Facility Configuration Study (Boomer et al. 1993). The cost of a solvent extraction system collocated with another processing facility is based on the cost differences between two pretreatment facilities with and without the solvent extraction system. These two facilities are identified as Solvent Extraction B (SOLEX B) and Sludge Wash B (SWB), with and without the solvent extraction, respectively, in the reference report (Boomer et al. 1993). The capital costs for these two facilities are updated for this report. A summary of the updated SWB cost estimate is found in Appendix B. The difference in costs between SOLEX B and SWB provides a basis for the cost difference of a LAW vitrification facility with and without solvent extraction capability. The difference in capital costs associated with transuranics removal by solvent extraction is $\$ 1.22$ billion. The difference in operating costs associated with operation of the solvent extraction system is identified by the difference in operating costs for the SOLEX $B$ and SWB facilities of $\$ 6.69$ billion (Boomer et al. 1993).

The in-facility process for strontium removal by solvent extraction treatment of all wastes is expected to remove $3.4 \mathrm{MCi}$ of the $3.5 \mathrm{MCi}{ }^{90} \mathrm{Sr}$ for further pretreatment. The removal of $3.4 \mathrm{MCi}$ of ${ }^{90} \mathrm{Sr}$ at a total cost of $\$ 7.9$ billion results in a radionuclide removal cost of $\$ 2,320 / \mathrm{Ci}$ of ${ }^{90} \mathrm{Sr}$ and is not economically practical. No economic analysis is currently available which provides the cost of solvent extraction for selective treatment of tank wastes (i.e., small scale processing). 


\subsubsection{Transuranic Removal}

The liquid fraction for further pretreatment contains approximately $0.0136 \mathrm{MCi}$ soluble TRU, rounded to $0.01 \mathrm{MCi}$, for further separation. Technology options considered in this study for removal of soluble TRU from the waste supernatants and wash liquors are:

(1) complexant destruction, (2) deactivation of the complexants, (3) precipitation by chemical addition, and (4) solvent extraction. No further removal is provided for the $0.004 \mathrm{MCi}$ of entrained, insoluble TRU fraction resulting from washing and decanting inefficiencies.

An analysis of DST radionuclide removal requirements on a tank-by-tank basis (Schulz 1995) has determined that only three DSTs (241-AN-102, 241-AN-107 and 241-AY-101) require some removal of soluble TRU from supernatants to meet the NRC Class $\mathrm{C}$ requirement of less than $100 \mathrm{nCi}$ TRU/g glass. These three tanks are classified as $\mathrm{CC}$ wastes and contain an estimated $0.0054 \mathrm{MCi}$ ( 56 percent) of the totall soluble TRU.

The CC supernatant contains multivalent cations of radionuclides such as TRU and strontium in greater concentrations than normal in alkaline solutions. This increased concentration occurs because of the presence of complexants added during previous strontium and cesium recovery campaigns in B Plant.

4.2.3.1 Transuranics Removal by Complexant Destruction in All Wastes. The complexant deactivation of all wastes is discussed in Section 4.2.2.2 for removal of soluble strontium and is applicable to TRU removal. The complexant destruction process will remove an estimated $0.0099 \mathrm{MCi}$ of the $0.01 \mathrm{MCi}$ of soluble TRU in addition to the removal of the $1.87 \mathrm{MCi}$ of soluble ${ }^{90} \mathrm{Sr}$.

Technical Practicality of Complexant Destruction. As discussed in Section 4.2.2.2.1, TRU removal by complexant deactivation of all wastes is not technically practical.

Cost of Complexant Destruction. No economic analysis is provided since the technology is not technically practical.

4.2.3.1.1 Transuranic Removal by Complexant Deactivation in Selected Wastes. The complexant deactivation of selected CC wastes (241-AN-102, 241-AN-107, and 241-AY-101) was discussed in Section 4.2.2.2.1 for removal of soluble strontium and is applicable to TRU removal. The complexant deactivation process will remove an estimated $0.005 \mathrm{MCi}$ of the $0.0054 \mathrm{MCi}$ of the soluble TRU in the CC wastes.

Technical Practicality of Complexant Deactivation in Selected Wastes. As discussed in Section 4.2.2.2.1 for strontium removal, complexant deactivation for TRU removal is considered not technically practical.

Cost of Complexant Deactivation in Selected Wastes. No economic analysis is provided since the technology is not technically practical. 
4.2.3.2 Transuranic Removal From All Wastes by Solvent Extraction. The solutions that contain transuranics in an alkaline solution are acidified using nitric acid. Transuranics are removed from the acidified solution using a solvent extraction system similar to the processes described in the Tank Waste Technical Options Report (Boomer et al. 1993). Transuranic recovery by solvent extraction is part of Solvent Extraction B. The transuranic extraction process is generally called TRUEX.

Technical Practicality of Solvent Extraction for All Wastes. Solvent extraction separation using TRUEX has been demonstrated through laboratory testing and pilot scale testing. Solvent extraction using other solvent extraction processes has previously been used in Reduction Oxidation (REDOX) and Plutonium-Uranium Extraction (PUREX) at the Hanford Site and at other sites to recover uranium, plutonium and neptunium. Transuranics removal by TRUEX is technically practical based on the extensive laboratory and pilot scale tests.

Cost of Solvent Extraction for All Wastes. The cost for transuranic removal by solvent extraction is based on facility designs presented in the Facility Configuration Study (Boomer et al. 1993). The cost of a solvent extraction system collocated with another processing facility is based on the cost differences between two pretreatment facilities with and without the solvent extraction system. These two facilities are identified as SOLEX B and SWB, with and without the solvent extraction, respectively, in the reference report (Boomer et al. 1993). The capital costs for these two facilities are updated for this report. A summary of the updated SWB cost estimate is found in Appendix B. The difference in costs between SOLEX B and SWB provides a basis for the cost difference of a LAW vitrification facility with and without solvent extraction capability. The difference in capital costs associated with transuranics removal by solvent extraction is $\$ 1.22$ billion. The difference in operating costs associated with operation of the solvent extraction system is identified by the difference in operating costs for the SOLEX B and SWB facilities of $\$ 6.69$ billion (Boomer et al. 1993).

The solvent extraction treatment of wastes is expected to remove $0.01 \mathrm{MCi}$ of the transuranics. The removal of $0.01 \mathrm{MCi}$ transuranics at a total cost of $\$ 7.9$ billion results in a radionuclide removal cost of more than $\$ 790,000 / \mathrm{Ci}$ of transuranics and is not economically practical.

4.2.3.3 Hydroxide Precipitation of Transuranics from Selected Wastes. The analysis of DST radionuclide removal requirements (Schulz 1995) indicates that TRU removal for the three CC waste DSTs (241-AN-102, 241-AN-107 and 241-AY-101) can be attained with additions of $\mathrm{NaOH}$ as demonstrated by laboratory testing (Herting 1993, 1994a, 1994b, Washington 1990). The results indicate that wastes in tanks 241-AN-107 and 241-AY-101 can produce $<100 \mathrm{nCi}$ TRU/g LAW glass by adjustment of the supernatants to $3.0 \mathrm{M}$ and $1.5 M$ hydroxide ion, respectively, and addition of $0.01 M$ ferric ion to serve as a $\mathrm{Fe}(\mathrm{OH})_{3}$ carrier precipitate. Data for hydroxide adjustment for 241-AN-102 are not available at this time. The available laboratory data indicate that TRU removal increases with additional contact time. The development work also indicates that approximately 20 percent of the soluble strontium may be co-precipitated by the hydroxide precipitation process $(0.1 \mathrm{MCi}$ of the $0.57 \mathrm{MCi}$ soluble ${ }^{90} \mathrm{Sr}$ in the three $\mathrm{CC}$ taniss). 
Laboratory testing was also performed using $0.1 M \mathrm{Fe}\left(\mathrm{NO}_{3}\right)_{3}$ and $3.0 \mathrm{M} \mathrm{NaOH}$ for the precipitation of TRU. The TRU is adsorbed on the surface of the ferric hydroxide floc formed by precipitation. In-tank mixers are required to keep the floc in suspension and available to the soluble TRU for adsorption. As demonstrated from laboratory testing, precipitation of $\mathrm{Fe}_{2} \mathrm{O}_{3} \cdot \mathrm{xH}_{2} \mathrm{O}$ from $\mathrm{CC}$ waste removes 84 to 96 percent of the ${ }^{241} \mathrm{Am}$ and 60 to 75 percent of the soluble plutonium (Schulz 1995). The development work also indicates that approximately 50 percent of the soluble strontium may also be removed by the ferric hydroxide precipitation process $\left(0.28 \mathrm{MCi}\right.$ of the $0.57 \mathrm{MCi}$ soluble $\left.{ }^{90} \mathrm{Sr}\right)$. However, the addition of iron impacts the volume of HLW glass produced.

Technical Practicality of Hydroxide Precipitation for Selected Wastes. It has been determined (Schulz 1995) that only three DSTs require some removal of soluble TRU from supernatants. Laboratory testing has been performed with waste from two of the three CC tanks and in-tank mixing with chemical addition has been well-demonstrated. Therefore, this technology is considered to be technically practical. For three $\mathrm{CC}$ tanks, containing an estimated $0.0054 \mathrm{MCi}$ soluble TRU, $0.004 \mathrm{MCi}$ is removed using hydroxide precipitation. The quantity of co-precipitated ${ }^{90} \mathrm{Sr}$ for this technology $(0.1 \mathrm{MCi})$ is subtracted from the total ${ }^{90} \mathrm{Sr}$ to LAW.

Cost of Hydroxide Precipitation for Selected Wastes. The total costs for adjustment of the hydroxide concentration and addition of $0.01 M^{\prime}$ iron in the DSTs (several weeks or months before retrieval and solids/liquid separation) is $\$ 6$ million to $\$ 18$ million (Appendix B provides additional cost data).

The addition of $19 M \mathrm{NaOH}$ to the three tanks to obtain a final concentration of $3 M \mathrm{NaOH}$ increases the total tank waste sodium by $250 \mathrm{MT}$ or 0.14 equivalent vaults. The disposal cost per vault of solidified LAW is approximately $\$ 10$ million (Slaathaug 1995, Table F-36) and the incremental Na usage results in $\$ 1.4$ million increase in LAW disposal costs. The addition of $\mathrm{NaOH}$ to the tanks is assumed to cost $\$ 0.6$ million. Therefore, the LAW cost increase is approximately $\$ 2$ million.

The addition of the $0.01 M$ iron results in an additional 5 to 21 canisters of HLW glass. The canisters are assumed to contain $1.26 \mathrm{~m}^{3}$ of glass and a maximum $\mathrm{Fe}_{2} \mathrm{O}_{3}$ content of 12 wt\% (Orme 1994). The minimum HLW canister impact is based on $50 \mathrm{wt} \% \mathrm{Fe}_{2} \mathrm{O}_{3}$ if the $\mathrm{HLW}$ facility is processing glass at less than the $12 \mathrm{wt} \% \mathrm{Fe}_{2} \mathrm{O}_{3}$ limit and the maximum $\mathrm{HLW}$ canister impact is based on the 12 wt $\% \mathrm{Fe}_{2} \mathrm{O}_{3}$ limit. With an incremental HLW canister cost of $\$ 745,000$ per HLW canister (Slaathaug 1995), this results in an additional operating cost of approximately $\$ 3.7$ to $\$ 16$ million.

The resulting $\$ 6$ million to $\$ 18$ million total cost for removal of approximately $0.004 \mathrm{MCi}$ TRU (from three tanks) necessary to meet the $<100 \mathrm{nCi} / \mathrm{g}$ criteria results in a cost of $\$ 1,500$ to $\$ 4,500 / \mathrm{Ci}$ TRU. If the $0.1 \mathrm{MCi}$ of co-precipitated ${ }^{90} \mathrm{Sr}$ is included, the cost is reduced to $\$ 60 / \mathrm{Ci}$ to $\$ 170 / \mathrm{Ci}$. 
Cost of Ferric Hydroxide Precipitation for Selected Wastes. The addition of $0.1 M$ $\mathrm{Fe}\left(\mathrm{NO}_{3}\right)_{3}$ and $3.0 \mathrm{M} \mathrm{NaOH}$ for precipitation of TRU to the three $\mathrm{CC}$ tanks results in a maximum additional 50 to 210 canisters of HLW glass. The canisters are assumed to contain $1.26 \mathrm{~m}^{3}$ of glass and a maximum $\mathrm{Fe}_{2} \mathrm{O}_{3}$ content of $12 \mathrm{wt} \%$ (Orme 1994). The minimum $\mathrm{HLW}$ canister impact is based on $50 \mathrm{wt} \% \mathrm{Fe}_{2} \mathrm{O}_{3}$ if the $\mathrm{HLW}$ facility is processing glass at less than the $12 \mathrm{wt} \% \mathrm{Fe}_{2} \mathrm{O}_{3}$ limit and the maximum $\mathrm{HLW}$ canister impact is based on the 12 wt $\% \mathrm{Fe}_{2} \mathrm{O}_{3}$ limit. With an incremental HLW canister cost of $\$ 745,000$ per HLW canister (Slaathaug 1995), this results in an additional operating cost of approximately $\$ 37$ to $\$ 160$ million. The incremental LAW costs are \$2 million due to the additional sodium (see economics of hydroxide precipitation) and provides a $\$ 39$ million to $\$ 162$ million total cost for removal of approximately $0.005 \mathrm{MCi}$ TRU and $0.28 \mathrm{MCi}$ co-precipitated ${ }^{90} \mathrm{Sr}$. This results in a removal cost of $\$ 140 / \mathrm{Ci}$ to $\$ 570 / \mathrm{Ci}$.

4.2.3.4 Transuranics Removal by Complexant Deactivation in Selected Wastes. The complexant deactivation of selected CC wastes (241-AN-102, 241-AN-107 and 241-AY-101) is discussed in Section 4.2.2.2.1 for removal of soluble strontium. An analysis of in-tank heat and digest to deactivate the complexant in $\mathrm{CC}$ waste tanks was performed by Klem (1995). The complexant deactivation process will remove an estimated $0.005 \mathrm{MCi}$ of the $0.0054 \mathrm{MCi}$ of the soluble TRU in addition to the removal of the $0.54 \mathrm{MCi}$ of soluble ${ }^{90} \mathrm{Sr}$.

Technical Practicality of Complexant Deactivation for Selected Wastes. The complexant deactivation process for $\mathrm{CC}$ wastes is expected to require 4.2 to 14.3 years in-tank at $100^{\circ} \mathrm{C}$ and the final performance is uncertain. Therefore, complexant deactivation is not technically practical.

Cost of Complexant Deactivation for Selected Wastes. No economic analysis is provided since the technology is not technically practical.

\subsubsection{Technetium-99 Removal}

The soluble ${ }^{99} \mathrm{Tc}$ fraction of the tank waste contains an estimated $0.0228 \mathrm{MCi}$. Incorporating the entire quantity of technetium $(0.032 \mathrm{MCi}$, soluble and insoluble) into the LLW glass would result in approximately $0.2 \mathrm{Ci}^{99} \mathrm{Tc} / \mathrm{m}^{3}$ glass. On a tank-by-tank basis, no additional removal of ${ }^{99} \mathrm{Tc}$ is required to meet the Class $\mathrm{C}$ limit of $3 \mathrm{Ci} / \mathrm{m}^{3}$ in the solidified LAW (Schulz 1995). However, ${ }^{99} \mathrm{Tc}$ removal may be necessary to meet the disposal system requirements based on the performance assessment.

No demonstrated technology exists for in-tank precipitation of soluble ${ }^{99} \mathrm{Tc}$ from DST waste solutions. Candidate precipitation compounds include $\mathrm{Tc}_{2} \mathrm{~S}_{7}$ and tetraphenylphosphonium pertechnetate (Schulz et al. 1995). Candidate technology options for removal of soluble technetium in the pretreatment or vitrification facility include mixed bed ion exchange, anion resin ion exchange, and volatilization. 
4.2.4.1 Mixed Bed Technetium and Cesium Ion Exchange. Argonne National Laboratory and Eichrom Industries, Inc., have developed a technetium-specific resin for use in laboratory and analytical applications (Horwitz 1995). Preliminary scoping studies of applying resin to large scale processing of Hanford Site tank wastes has been performed. The resin is tailored on the molecular level to specifically absorb technetium. The resin, named $\mathrm{Tc}$ Spec 5 , is commercially available as an analytical reagent. Tc Spec 5 strongly absorbs technetium from solutions greater than $4 M$ salt and technetium elutes with water or dilute nitric acid. These properties are identical to the chemical behavior of cation ion exchange resins used for cesium removal. Operation of a single ion exchange column system containing a mixture of the resins allows simultaneous recovery of technetium and cesium. A mixed bed ion exchange system is a common industrial practice and is significantly less expensive than building and operating two ion exchange systems in series.

The laboratory work to date for the application to Hanford Site tank wastes is initial proof of principal experiments with 241-SY-101 simulant only to determine distribution coefficients. Use of TcSpec 5 in a mixed bed configuration eliminates the use of a water scrub to displace interstitial feed from the column before cesium elution. The water displacement flush would prematurely elute technetium. The water flush would have to be replaced with draining the interstitial feed from the column. The less efficient removal of feed sodium from the column by draining would have a currently undefined impact by increasing HLW volume. If the increase in HLW volume is excessive, alternate designs with Tc Spec 5 columns in series with the cesium ion exchange columns would be investigated. Significant additional cold and hot laboratory development work is required.

Technical Practicality of Mixed Bed Ion Exchange. The mixed bed ion exchange recovery of ${ }^{99} \mathrm{Tc}$ with $\mathrm{Tc} \cdot \mathrm{Spec}$ is not technically practical at this time.

Cost of Mixed Bed Ion Exchange. No economic analysis is provided since the technology is not technically practical.

4.2.4.2 Technetium Anion Exchange. Technetium can be removed from alkaline solutions high in sodium with anion exchange resins. The removal of technetium with a strong base anion exchange resin has been demonstrated with a single large scale batch loading of the resin at the Hanford Site (Beard and Caudill 1964). The loaded resin was shipped to another DOE site for elution. Multiple load and elution cycles of technetium on ion exchange resins has not been demonstrated.

The current design basis for evaluation of technetium ion exchange is based on a strong-base organic anion exchange resin (Schultz 1980). More recent analyses have been performed on the sorption of technetium from DSSF simulants using Reillex-HPQ ${ }^{6}$ anion exchange resin and is limited to hot lab scale experiments.

${ }^{6}$ Reillex-HPQ is a trademark of Reilly Industries Inc. 
The technetium ion exchange process loads technetium from the alkaline feed stream onto the resin by passing the feed through a column of resin particles. When breakthrough of technetium occurs in the column raffinate, the feed is diverted to a parallel column and the loaded column is flushed with water. Following the flushing operation, the technetium is eluted from the column with strong nitric acid $\left(6 \mathrm{M} \mathrm{HNO}_{3}\right)$. Following the technetium elution, the column is flushed with water. The column is then ready for another feed loading cycle.

The technetium product stream eluted from the column with nitric acid is concentrated and the bulk of the nitric acid boiled off from the technetium solution for fractionation and recycle to the next elution cycle. The residual nitric acid in the concentrated technetium product is then neutralized with sodium hydroxide. The neutralized technetium concentrate is then transferred to a DST for interim storage before vitrification as HLW.

Technical Practicality of Anion Exchange. The technetium ion exchange process meets the definition of being techrically practical based on the large demonstration recovery of $27 \mathrm{Ci}$ of ${ }^{99} \mathrm{Tc}$ at the Hanford Site using technetium ion exchange (Beard and Caudill 1964). However, information contained in Schroeder et al. (1995) indicate some serious questions for application of ion exchange to existing Hanford Site tank wastes due to the uncertainties in the valence state of the technetium (i.e., the pertechnate ion, valance 7 , is extractable but other oxidation states are not extractable.) Therefore, ${ }^{99} \mathrm{Tc}$ anion exchange is not considered technically practical at this time.

Cost of Anion Exchange. The cost for technetium removal by ion exchange is based on facility and equipment designs presented in the Tank Waste Technical Options Report (Boomer et al. 1993). The cost of a technetium ion exchange system collocated with another processing facility is based on the cost differences between two pretreatment facilities with and without the technetium ion exchange process. These two facilities are identified as Sludge Wash D (SWD) and Sludge Wash B (SWB), with and without the technetium ion exchange, respectively, in the reference report (Boomer et al. 1993). Both facilities include sludge washing, solids/liquids separation, and cesium ion exchange. The capital costs for these two facilities are updated for this report. Summaries of the updated SWD and SWB cost estimates are found in Appendix B. The difference in costs between SWD and SWB provides a basis for the cost difference of a LAW treatment or vitrification facility with and without technetium ion exchange capability. The difference in capital costs associated with technetium ion exchange processing is $\$ 260$ million. The difference in operating costs associated with operation of the technetium ion exchange processing is identified by the difference in operating costs for the SWD and SWB facilities of $\$ 400$ million (Boomer et al. 1993).

The technetium ion exchange process recovers $0.0226 \mathrm{MCi}$ of ${ }^{99} \mathrm{Tc}$ for a total cost of $\$ 660$ million. This results in a cost of $\$ 29,000 / \mathrm{Ci}^{99} \mathrm{Tc}$ and is not economically practical.

4.2.4.3 Technetium Volatilization. The volatilization of technetium from glass melters and calciners is an intrinsic feature of the operating temperatures. Processes and melters for the vitrification of HLW glass are designed to suppress volatilization and recycle volatilized 
technetium to the melter. Design of the LAW melter features, control of melter chemistry, and removal of technetium from the offgas stream with minimal recycle to the melter results in the LAW melter system providing technetium removal. The degree of removal that can be obtained by this process needs to be confirmed by additional development.

Reviews of technetium volatility from glasses have shown up to 95 percent removal (DF of 20) of technetium (Langowski 1995, Vida 1994). Melter design can be modified to enhance technetium volatility by disruption of the cold cap, sparging the molten glass, or use of a gas heated melter. The melter chemistry can be modified to enhance technetium volatility by increased temperature and/or changing from reducing to oxidizing conditions.

The addition of technetium removal to a volatilization system requires neutralization with sodium hydroxide and addition of sodium sulfide to the scrubber concentrate for technetium precipitation as $\mathrm{Tc}_{2} \mathrm{~S}_{7}$. The FY 1995 flowsheet for TWRS Optimized Processing Strategy (Slaathaug 1996a) shows $\mathrm{NaOH}$ and $\mathrm{Na}_{2} \mathrm{~S}$ are added to the concentrate and before filtration for separation of the technetium sulfide. The technetium depleted filtrate is recycled to the melter feed tank. The $\mathrm{Tc}_{2} \mathrm{~S}_{7}$ is slurried to a DST for interim storage before HLW vitrification. An alternate method of ${ }^{99} \mathrm{Tc}$ removal from the concentrate is to use absorption on Tc:Spec 5 in a column.

Technical Practicality of Volatilization. The technetium volatilization process is not technically practical because the process has not been adequately demonstrated.

Cost of Volatilization. No economic analysis is provided since the technology is not technically practical.

\subsubsection{Selenium-79 Removal}

The tank waste contains an estimated $0.00103 \mathrm{MCi}$ of ${ }^{79} \mathrm{Se}$. All of the selenium in the tank waste is assumed to be soluble.

No demonstrated technology exists for in-tank precipitation of soluble ${ }^{79} \mathrm{Se}$ from DST waste solutions. In-tank precipitation would allow selenium to be removed by solids/liquids separations process discussed in Section 4.1.1. Although selenium is known to precipitate from water upon addition of sulfur dioxide, it is not known whether this technique would work as an in-tank precipitation process due to the very small amount of selenium present in the waste. A cursory review of commercial selenium recovery processes has not revealed any processes suitable for direct removal of selenium from the Hanford Site tank waste solutions during pretreatment. Laboratory methods for removal of selenium have not been reviewed for scaled up application in a pretreatment or vitrification operation. Ion exchange processes may exist, but the identification of selenium specific ion exchange resin has not been pursued. 
4.2.5.1 Selenium Volatilization. The volatilization of selenium from commercial glass melters and the pyrometallurgical industry is a well known phenomena. Selenium is commercially recovered by the roasting of copper ores and residues from electrolytic copper recovery. Selenium is recovered from roasting flue deposits by sublimation or leaching.

The commercial glass industry has routinely experienced selenium losses of up to 80 percent or more (Kirk-Othmer 1982). Melter design can be modified to enhance selenium volatility by disruption of the cold cap, sparging the molten glass, or use of a gas heated melter. The melter chemistry can be modified to enhance selenium volatility by increased temperature and/or by changing from reducing to oxidizing conditions. Melter design could also include removal of selenium from the offgas stream with no recycle to the melter.

An option for selenium purification involves precipitation with sulfur dioxide in the scrubber solution from a LAW melter and offgas systern. It is assumed that selenium can be co-precipitated with technetium by neutralization of the scrubber concentrate with sodium hydroxide and addition of sodium sulfide to precipitate selenium as a sludge

(Kirk-Othmer 1982). The selenium filtrate can be recycled to the melter feed tank. The selenium sludge and $\mathrm{Tc}_{2} \mathrm{~S}_{7}$ is slurried to a DST for interim storage before HLW vitrification.

Technical Practicality of Selenium Volatilization. The selenium volatilization process is not technically practical since the process has not been demonstrated at plant scale for radioactive wastes.

Cost of Selenium Volatilization. No economic analysis is provided since the technology is not technically practical.

\subsubsection{Carbon-14 Removal}

The estimated inventory of ${ }^{14} \mathrm{C}$ in the tank wastes is $0.0053 \mathrm{MCi}{ }^{14} \mathrm{C}$. The estimated inventory of $0.0053 \mathrm{MCi}{ }^{14} \mathrm{C}$ represents $120 \mathrm{~kg}$ of the ${ }^{14} \mathrm{C}$ isotope and is diluted by approximately $1,800,000 \mathrm{~kg}$ of natural carbon in the tank wastes as carbonate and organics. The chemistry of carbon results in ${ }^{14} \mathrm{C}$ being distributed in supernatants and solids of all tanks. The organic carbon and carbonate content of the wastes will be converted to carbon dioxide, $\mathrm{CO}_{2}$, as a result of the $\mathrm{LAW}$ vitrification process. In the vitrification process a total of $6,500,000 \mathrm{~kg}$ of $\mathrm{CO}_{2}$ will be released in the offgas. To capture and remove the ${ }^{14} \mathrm{C}$, the $6,500,000 \mathrm{~kg}$ of $\mathrm{CO}_{2}$ could be absorbed in slaked lime as $15,000,000 \mathrm{~kg}$ of $\mathrm{CaCO}_{3}$.

An analysis of the impact of not removing ${ }^{14} \mathrm{C}$ and ${ }^{129} \mathrm{I}$ indicates the maximum offsite individual will receive a 50 -year dose commitnent from atmospheric releases of less than $0.7 \mathrm{mrem} / \mathrm{yr}$ (Colby 1994). This is 0.2 percent of the national average individual dose from background of $300 \mathrm{mrem} / \mathrm{yr}$.

Technical Practicality of Carbon Removal. There is no currently known isotopic enrichment technology that can separate the ${ }^{14} \mathrm{C}$ isotope from natural ${ }^{12} \mathrm{C}$ for Hanford Site tank wastes. Therefore, ${ }^{14} \mathrm{C}$ separation for disposal as $\mathrm{HLW}$ is not technically practical. 
Cost of Carbon Removal. No economic analysis is provided since the technology is not technically practical.

\subsubsection{Iodine-129 Removal}

The estimated inventory of ${ }^{129} \mathrm{I}$ in the tank wastes is $0.000051 \mathrm{MCi}(51 \mathrm{Ci})$. Iodine confinement technology that has been developed in the nuclear industry was aimed at relatively high concentrations and purity as released in reactor accidents or from nuclear fuel reprocessing dissolvers. The relatively high concentrations and absence of organics allows evolution of the resulting iodine compounds into the vapor phase and sorption with solids or liquids. The absence of chlorides and fluorides also eliminates competitive coabsorption of halides on solid sorbants. However, the alkaline tank wastes contain significant quantities of halides and organic materials.

Joule heated melters used for vitrification of the LAW typically operate under reducing conditions to protect the electrodes from catastrophic oxidation. Operation under reducing conditions will result in significant organic content in the melter offgas. The technology for organic iodide confinement in reprocessing was never fully satisfactory, and efforts were made to limit organic input into the dissolver system (the amount of PUREX organic diluent soluble in recycle water from the acid fractionator was of concern).

The iodine concentration in the tank wastes is typically 1,000 to 10,000 times lower than would exist in commercial fuel dissolver solutions that iodine removal technology was developed for. Thus, there is no technically practical iodine removal and confinement technology for tank wastes.

The path of ${ }^{129} \mathrm{I}$ in the LAW vitrification process is release to the atmosphere and an unknown quantity to the chloride purge stream. The chemistry of iodine suggests the potential removal of iodine from the chloride purge stream in the LAW offgas treatment system. The similar chemical behavior of the halides (fluorine, chlorine, and iodine) suggest that significant quantities, 20 to 80 percent, of the ${ }^{129}$ I inventory may accumulate with the chloride and fluoride streams concentrated in the offgas treatment system for purge and disposal as grout. If ${ }^{129}$ I concentrates in these streams, technology could be investigated to determine if cost effective systems for separation of ${ }^{129} \mathrm{I}$ from mixed chlorides and fluorides exist.

An analysis of the impact of not removing ${ }^{14} \mathrm{C}$ and ${ }^{129} \mathrm{I}$ indicates that if all is released to the atmosphere, the maximum offsite individual will receive a 50-year dose commitment from atmospheric releases of less than $0.7 \mathrm{mrem} / \mathrm{yr}$ (Colby 1994). This is 0.2 percent of the national average individual dose from background of $300 \mathrm{mrem} / \mathrm{yr}$.

Technical Practicality of Iodine Removal. ${ }^{129} 1$ removal is considered not technically practical because no technology has been demonstrated for the relatively small concentrations in the Hanford Site tank wastes. 
Cost of Iodine Removal. No economic analysis is provided since no ${ }^{129} \mathrm{I}$ removal technology has been provided.

\subsubsection{Tritium Removal}

Tritium $\left({ }^{3} \mathrm{H}\right)$ contained in the tank wastes is estimated to be $10,000 \mathrm{Ci}$ (Colby 1994) and will be discharged from the pretreatment and waste vitrification facilities in the process condensates as tritiated water. The excess process condensates that are not recycled within the TWRS processing operation are routed to the 200 Area Effluent Treatment Facility (ETF).

The ETF process does not remove the tritium isotope from the natural hydrogen in the water. The separation of tritium from the treated condensate was evaluated and it was determined not to be technically practical (DOE 1994b).

The chosen alternative for disposal of the tank waste tritium in the treated water is to discharge this water to the subsurface and allow tritium to decay into non-radioactive helium before it reaches the Columbia River. The effluent infiltration gallery, also known as the State Approved Land Disposal Site (SALDS) is located just north of the 200 West Area. A study (Golder Associates 1990) shows that SALDS provides a 105-year travel time before tritium bearing ground water discharges to the Columbia River. The study concludes that through natural decay and subsurface dispersion, the concentration of tritium will be well within drinking water standards when it reaches the Columbia River.

\subsubsection{Tin Removal}

The tank waste for pretreatment contains an estimated $0.0016 \mathrm{MCi}$ of insoluble ${ }^{126} \mathrm{Sn}$. No technologies for tin removal were reviewed for this evaluation. For performance assessment studies, some tin to the LAW fraction is assumed to ensure continued consideration of tin for intruder dose consequences. The ${ }^{126} \mathrm{Sn}$ is not a significant contributor to the total curies and, as discussed for other radionuclides with small inventories, would not be economically practical for removal.

\subsubsection{Uranium Removal By Solvent Extraction for All Wastes.}

The soluble waste fraction contains an estimated $0.00006 \mathrm{MCi}(60 \mathrm{Ci})$ of uranium isotopes. Uranium was routinely recovered and shipped as a product at the Hanford Site and other nuclear reprocessing facilities around the world. The technology most applied in the past for uranium is solvent extraction with tributyl phosphate in a hydrocarbon diluent. The solvent extraction recovery of uranium from the alkaline supernatants and dissolved salt cakes requires acidification of the supernatants and dissolved salts before the solvent extraction process. The acidification of tank wastes was idemonstrated by the recovery of both uranium 
and strontium from Hanford Site tank wastes followed by solvent extraction recovery in U Plant and B Plant, respectively.

The alkaline solutions that contain uranium are acidified using nitric acid. Uranium is removed from the acidified solution using a solvent extraction system similar to the processes described in the Tank Waste Technical Options Report (Boomer et al. 1993). The process is generally called TRUEX. Uranium is recovered by solvent extraction only when the TRUEX process is available and used after the supernatant is acidified. Since uranium exhibits alkaline solubility and is distributed over all the wastes, all wastes are assumed for treatment.

Technical Practicality of Solvent Extraction. Solvent extraction using other solvent extraction processes has previously been used in U Plant, REDOX and PUREX at the Hanford Site to recover uranium, plutonium and neptunium. No production scale processing using the TRUEX process has been performed on radioactive wastes similar to the Hanford Site tank wastes. However, uranium removal by solvent extraction separation using TRUEX is technically practical based on the extensive laboratory and pilot scale tests.

Cost of Solvent Extraction. The cost for uranium removal by solvent extraction is based on facility designs presented in the Tank Waste Technical Options Report (Boomer et al. 1993). The cost of a solvent extraction system collocated with another processing facility is based on the cost differences between two pretreatment facilities with and without the solvent extraction system. These two facilities are identified as Sludge Wash B (SWB) and Solvent Extraction B (SOLEX B), with and without the solvent extraction, respectively, in the reference report (Boomer et al. 1993). The capital costs for these two facilities have been updated for this report (see Appendix B for cost estimates). The difference in costs between SOLEX B and SWB provides a basis for the cost difference of a LAW vitrification facility with and without solvent extraction capability. The difference in capital costs associated with solvent extraction is $\$ 1.22$ billion. The difference in operating costs associated with operation of the solvent extraction system is identified by the difference in operating costs for the SOLEX B and SWB facilities of $\$ 6.69$ billion (Boomer et al. 1993).

The solvent extraction treatment of all wastes is expected to remove $60 \mathrm{Ci}$ of the soluble uranium. Combining the recovery of $3.4 \mathrm{MCi}$ soluble strontium, $0.0095 \mathrm{MCi}$ transuranics and $60 \mathrm{Ci}$ uranium results in a potential total recovery of $3.4 \mathrm{MCi}$ for about $\$ 7.9$ billion and results in a removal cost of approximately $\$ 2,320 / \mathrm{Ci}$. Solvent extraction for all wastes is considered not economically practical.

\subsubsection{Radionuclide Removal Technology Options Summary}

The radionuclide removal technology options discussed in the sections above are summarized in Tables 4-3 and 4-4. Table 4-3 addresses the "technically practical" criteria and summarizes the technology status of options discussed. Table 4-4 provides the costs and the MCi separated for the technologies determined to be technically practical. 
Table 4-3. Summary Table of Technology Maturity Assessment.

\begin{tabular}{|c|c|c|c|c|c|c|c|c|c|}
\hline \multirow{2}{*}{ 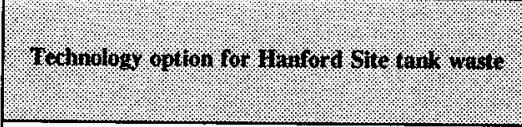 } & \multirow{2}{*}{$\begin{array}{l}\text { Techrivally } \\
\text { practical } \\
\text { Mieno) }\end{array}$} & \multirow{2}{*}{ Qonsept } & \multirow{2}{*}{ (colongand } & \multicolumn{2}{|c|}{ Berich rolle: } & \multicolumn{2}{|c|}{ 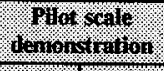 } & \multicolumn{2}{|c|}{ froduction grile use } \\
\hline & & & & collo & 160 & 801, & Ifou & Womperiforal & Novilat \\
\hline $\begin{array}{l}\text { Core - Previous Separations, Solids/Liquids } \\
\text { Separations }\end{array}$ & Yes & & & & & & & & \\
\hline Single-Cycle Cation Ion Exchange for ${ }^{137} \mathrm{Cs}$ & Yes & 8 & & & : & & & 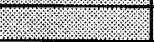 & \\
\hline Second-Cycle Cation Ion Exchange for ${ }^{137} \mathrm{Cs}$ & Yes & & & & & & & & \\
\hline In-Tank Precipitation for Cesium, All Wastes & No & & & & & & & & \\
\hline \begin{tabular}{|l|}
$\begin{array}{l}\text { In-Tank Precipitation for Cesium, Selective } \\
\text { Treatment }\end{array}$ \\
\end{tabular} & No & & & & & & & & \\
\hline Volatilization & $\mathrm{No}^{\mathrm{a}}$ & & & & & & & & \\
\hline Strontium Phosphate Precipitation, $\mathrm{Sr}_{3}\left(\mathrm{PO}_{4}\right)_{2}$ & No & & & & $\sqrt{2}$ & & & & \\
\hline $\begin{array}{l}\text { Complexant Destruction for }{ }^{90} \mathrm{Sr} \text { and TRU in All } \\
\text { Wastes }\end{array}$ & No & & & & & & & & \\
\hline 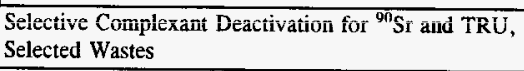 & No & & & & & & & & \\
\hline $\begin{array}{l}\text { Hydroxide Precipitation for TRU (and co-precipitated } \\
{ }^{90} \mathrm{Sr} \text { ) (Includes ferric hydroxide) } \\
\end{array}$ & Yes $^{b}$ & & & & & & & & \\
\hline Mixed Bed Ion Exchange $\left({ }^{99} \mathrm{Tc}\right.$ and $\left.{ }^{137} \mathrm{Cs}\right)$ & No & & & & & & & 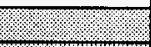 & \\
\hline Anion Resin Ion Exchange ( $\left.{ }^{99} \mathrm{Tc}\right)$ & No & & & & & & & & \\
\hline Solvent extraction: SREX & No & & 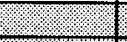 & & & & & & \\
\hline Solvent Extraction: TRUEX & Yes & & & & & & & & \\
\hline Solvent extraction: PUREX & Yes & & & & & & & 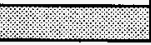 & \\
\hline
\end{tabular}

Slivitud are $=$ Demonstrated

CST $=$ crystalline silicotitanate

PUREX = Plutonium-uranium extraction

TRUEX $=$ Transuranic extraction

SREX = Strontium extraction

"Volatilization as a techmology for cesium removal is not considered to be technically practical. However, some radionuclide volatilization occurs intrinsic to the melter operation.

bechnology maturity is assessed based on laboratory testing with actual tank wastes from two of the three tanks requiring TRU removals. 
Table 4-4. Summary Table of Costs for Technically Practical Radionuclide Removal Technology Options.

\begin{tabular}{|c|c|c|c|c|c|c|c|c|c|}
\hline \multirow[b]{2}{*}{ 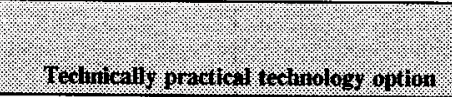 } & \multirow{2}{*}{ 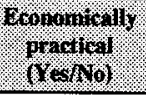 } & \multicolumn{3}{|c|}{ Crisi, ritilions. } & \multicolumn{4}{|c|}{ 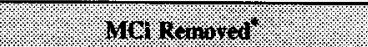 } & \multirow{2}{*}{ 9.6.t. } \\
\hline & & Garifal & Oporiting & rotal & (8) & iries. & 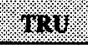 & 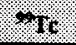 & \\
\hline $\begin{array}{l}\text { Baseline Process - Previous Separations, } \\
\text { Solids/Liquids Separations }\end{array}$ & & - & - & - & 77.5 & 60.2 & 0.120 & 0.009 & - \\
\hline $\begin{array}{l}\text { Single-Cycle Cation Ion Exchange, Selective } \\
\text { Removal (cesium concentrations }>0.05 \mathrm{Ci} / \mathrm{L} \text { ) }\end{array}$ & Yes & 380 & 335 & 715 & - & 29 & - & - & 25 \\
\hline $\begin{array}{l}\text { Single-Cycle Cation Ion Exchange, Selective } \\
\text { Removal (cesium concentrations }<0.05 \mathrm{Ci} / \mathrm{L} \text { ) }\end{array}$ & No & - & 267 & 267 & - & 4.1 & - & - & 65 \\
\hline Single Cycle Cation Ion Exchange & No & 380 & 602 & 982 & - & 33.1 & - & - & 30 \\
\hline Second-Cycle Cation lon Exchange & No & 275 & 145 & 420 & - & 1.0 & - & - & 420 \\
\hline $\begin{array}{l}\text { Hydroxide Precipitation for TRU and }{ }^{90} \mathrm{Sr} \text {, } \\
\text { Selective Treatment }\end{array}$ & Yes & 0 & $6-18$ & $6-18$ & 0.1 & - & 0.004 & - & $63-128$ \\
\hline $\begin{array}{l}\text { Ferric Hydroxide Precipitation for TRU and } \\
\text { 90 Sr, Selective Treatment }\end{array}$ & No & 0 & $39-162$ & $39-162$ & 0.28 & - & 0.005 & - & $140-570$ \\
\hline Solvent Extraction, TRUEX, PUREX & No & 1220 & 6690 & 7900 & - & - & 0.0095 & - & 800,000 \\
\hline
\end{tabular}

PUREX = Plutonium-uranium extraction

TRU $=$ Transuranic

TRUEX = Transuranic extraction

${ }^{* 14} \mathrm{C},{ }^{129} \mathrm{I},{ }^{3} \mathrm{H},{ }^{79} \mathrm{Se}$ and uranium are excluded from Table 4-4 due to insignificant quantities for removal, are minor contributors to total activity, and/or have no practical removal technology demonstrated. 


\subsection{RADIONUCLIDE SEPARATIONS TO MEET THE U.S. NUCLEAR REGULATORY COMMISSION GUIDELINES}

The goal of the LAW determination is to establish an inventory for all key radionuclides in the LAW that satisfies the regulatory intent of "technically and economically practical" and meets the limits and performance objectives of 10 CFR Part 61. This section summarizes the evaluation of the three NRC guidelines.

\subsection{REMOVE RADIONUCLIDES TO THE MAXIMUM EXTENT PRACTICAL}

Radionuclide removal technologies evaluated to meet the removal to the maximum extent practical guideline include previous removals, solids/liquids separation, and additional removal from the liquid fraction. Table 5-1 shows the radionuclide removal technologies and curies removed that are identified as both technically and economically practical. Additional removal technologies from the liquid fraction include selective TRU removal (i.e., three CC tanks) and cesium removal using a single-cycle ion exchange process. The selected technologies provide an initial selection criteria to estimate total curies remaining to be disposed in the vitrified LAW.

Transuranic removal must be provided for three DSTs to meet the Class $\mathrm{C}$ concentration limits and is assumed to use a hydroxide precipitation process. Some radionuclide removal will occur during vitrification of the LAW for the volatile species. However, curie removal during melter operation has not been added to the radionuclide removal totals.

Table 5-1. Maximum Practical Key Radionuclide Removal (December 31, 1999, Decay Date).

\begin{tabular}{|c|c|}
\hline Radionuclibe remoral toebrologe & HL W renored \\
\hline Previous removals & 84.1 \\
\hline Solid/liquids separations & 52 \\
\hline $\begin{array}{l}\text { Single-cycle cesium ion exchange }(>0.5 \mathrm{Ci} \\
\left.{ }^{137} \mathrm{Cs} / \mathrm{L}\right)\end{array}$ & $29^{137} \mathrm{Cs}$ \\
\hline $\begin{array}{l}\text { Selective hydroxide precipitation for } \\
\text { transuranic ( } 3 \mathrm{CC} \text { tanks) }\end{array}$ & $\begin{array}{c}0.004 \text { transuranic } \\
0.1{ }^{90} \mathrm{Sr}\end{array}$ \\
\hline
\end{tabular}




\subsection{MEET CLASS C CONCENTRATION LIMITS}

The second NRC guideline for classification of the LAW fraction is to incorporate the waste in a solid physical form at a concentration that does not exceed the applicable concentration limits for Class $\mathrm{C}$ low-level waste as set out in 10 CFR Part 61. Table 5-2 shows radionuclide concentrations that would result from vitrification of the liquid fraction of tank wastes after the proposed additional separation of radionuclides from the liquid fraction. As shown, radionuclide concentrations in the vitrified waste form would be Class $\mathrm{C}$ for transuranics, Class B for ${ }^{137} \mathrm{Cs}$ and ${ }^{90} \mathrm{Sr}$, and Class A for the others listed.

Table 5-2. Solidified Waste Radionuclide Concentrations After Supernatant Separations Versus 10 CFR Part 61 Limits.

\begin{tabular}{|c|c|c|c|c|c|}
\hline Radionuchide & 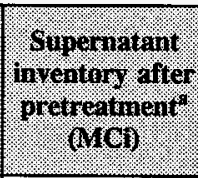 & 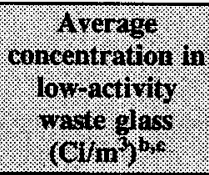 & 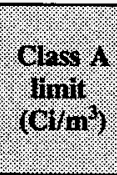 & $\begin{array}{l}\text { Class B } \\
\text { Hinit } \\
\text { (Ginini) }\end{array}$ & Minit (char \\
\hline${ }^{137} \mathrm{Cs}$ & 5 & 32 & 1 & 44 & 4,600 \\
\hline${ }^{90} \mathrm{Sr}$ & 3.4 & 22 & 0.04 & 150 & 7,000 \\
\hline Transuranics & 0.01 & $25 \mathrm{nCi} / \mathrm{g}$ & $10 \mathrm{nCi} / \mathrm{g}$ & NLE & $100 \mathrm{nCi} / \mathrm{g}$ \\
\hline${ }^{99} \mathrm{Tc}$ & 0.032 & 0.2 & 0.3 & -- & 3.0 \\
\hline${ }^{79} \mathrm{Se}$ & 0.00103 & $<0.006$ & NLE & NLE & NLE \\
\hline${ }^{14} \mathrm{C}$ & 0.0053 & $<0.03$ & 0.8 & NLE & 8.0 \\
\hline${ }^{129} I$ & 0.000051 & $<0.0003$ & 0.008 & NLE & 0.08 \\
\hline${ }^{3} \mathrm{H}$ & 0.01 & $<0.06$ & 40 & NLE & NLE \\
\hline${ }^{126} \mathrm{Sn}$ & 0.0016 & $<0.01$ & N/A & N/A & N/A \\
\hline Uranium & 0.001 & $<0.006$ & NLE & NLE & $\overline{\text { NLE }}$ \\
\hline
\end{tabular}

NLE $=$ No limit established.

${ }^{2}$ To be conservative, it is assumed that 100 percent of the ${ }^{99} \mathrm{Tc},{ }^{79} \mathrm{Se},{ }^{14} \mathrm{C},{ }^{3} \mathrm{H},{ }^{129} \mathrm{I}$, and ${ }^{126} \mathrm{Sn}$ inventories (soluble and insoluble fractions) are incorporated into the immobilized low-activity waste. See text in Section 4.0 for discussion.

${ }^{b}$ The sum of the fractions rule for mixtures of radionuclides has been applied.

'The low-activity waste volume is estimated to be $158,000 \mathrm{~m}^{3}$ of glass. 


\subsection{MEET DISPOSAL PERFORMANCE OBJECTIVES}

The third NRC guideline for classification of the LAW fraction as "incidental" waste is to manage the waste so that safety requirements for disposal performance are comparable to the performance objectives of 10 CFR Part 61. Defense wastes are also managed and disposed under guidance from DOE 5820.2A. The DOE order requires that a PA be prepared for the disposal system. A PA for LAW disposal has not yet been prepared.

The completed PA will identify areas of concern for long-term release of radionuclides to the environment from the disposal system. At that time, mitigating features, such as additional radionuclide removal and/or disposal system barriers, will be evaluated and incorporated into the treatment and disposal system as needed to meet PA requirements.

Although technetium is not a significant contributor to the total activity in the LAW, ${ }^{99} \mathrm{Tc}$ is the largest contributing radioisotope for meeting the maximum $4 \mathrm{mrem} / \mathrm{yr}$ criteria, within 10,000 years from closure, from the consumption of groundwater contaminated by the LAW disposal site.

Uranium isotopes and ${ }^{79} \mathrm{Se}$ are minor contributors to the total activity in the LAW but are significant with respect to the disposal performance objectives. ${ }^{79} \mathrm{Se}$ is significant with respect to meeting the maximum $4 \mathrm{mrem} / \mathrm{yr}$ criteria, within 10,000 years from closure, from the consumption of groundwater contaminated at the LAW disposal site.

Sensitivity studies of LAW disposal system features indicate that the exposure from ${ }^{99} \mathrm{Tc}$ can exceed the $4 \mathrm{mrem} / \mathrm{yr}$ criteria if the LAW glass is disposed without the use of engineered barriers (Mann et al. 1995). The assumptions used in the current environmental assessment calculations are considered conservative. The studies indicate that a LAW ${ }^{99} \mathrm{Tc}$ inventory reduction, of less than a factor of 10 , will substantially limit the contribution of the ${ }^{99} \mathrm{Tc}$ to the first dose peak which arrives at about 10,000 years. The LAW inventory reduction can be met by a combination of accurate definition of the tank waste inventory and providing some removal of soluble ${ }^{99} \mathrm{Tc}$. A combination of engineered barriers, and ${ }^{99} \mathrm{Tc}$ removal can mitigate the potential of exceeding the $4 \mathrm{mrem} / \mathrm{yr}$ criteria during the first 10,000 years.

Decisions made for removal of ${ }^{99} \mathrm{Tc},{ }^{79} \mathrm{Se}$ and uranium isotopes will be based on potential performance assessment impacts, not the total combined activity in the onsite disposed LAW. 


\subsection{PROPOSED DETERMINATION OF HANFORD SITE TANK WASTE CLASSIFICATION}

It is proposed that radionuclides be separated from Hanford Site tank waste so that those remaining in the LAW fraction not exceed the quantities listed in Table 5-3. For comparison purposes, Table 5-3 also includes the previous NRC determination for DST waste only.

Table 5-3. Comparison of Previous and Proposed

U.S. Nuclear Regulatory Commission Determinations.

\begin{tabular}{|c|c|c|}
\hline (1.10.0.1.0. & $\begin{array}{l}\text { Prefilous NRC: } \\
\text { deternination: }\end{array}$ & $\begin{array}{l}\text { Proposed KRT } \\
\text { detcraination' }\end{array}$ \\
\hline Scope, number of waste tanks & 28 DSTs & 28 DSTs and 149 SSTs \\
\hline Low-activity waste (LAW) form & Grout & Glass \\
\hline Low-activity waste volume, $\mathrm{m}^{3}$ & 233,000 & 158,000 \\
\hline \multicolumn{3}{|l|}{ Radionuclides in LAW (MCi) } \\
\hline${ }^{137} \mathrm{Cs}$ & 6 to 7 & 5 \\
\hline${ }^{90} \mathrm{Sr}$ & 1 to 8 & 3.4 \\
\hline Transuranics & 0.002 to 0.01 & 0.01 \\
\hline${ }^{99} \mathrm{Tc}$ & 0.016 to 0.028 & $<0.03^{\mathrm{c}}$ \\
\hline${ }^{79} \mathrm{Se}$ & $\cdots$ & $<0.001$ \\
\hline${ }^{14} \mathrm{C}$ & 0.0027 & $<0.0053$ \\
\hline${ }^{129} \mathrm{I}$ & 0.000033 & $<.000051$ \\
\hline${ }^{3} \mathrm{H}$ & -- & $<0.01$ \\
\hline${ }^{126} \mathrm{Sn}$ & -- & $<0.0016^{c}$ \\
\hline Uranium & -- & $<0.001^{\mathrm{c}}$ \\
\hline Total (without daughters) & 7 to 15 & 8.5 \\
\hline
\end{tabular}

DST $=$ Double-shell tank

NRC $=$ U.S. Nuclear Regulatory Commission

SST $=$ Single-shell tank

-- = No value established

${ }^{2}$ Decay date December 31, 1995

'Decay date December 31, 1999.

${ }^{c}$ And as required by the Performance Assessment.

It is concluded that cesium removal from liquid fraction and TRU removal from CC tanks before LAW vitrification, represents radionuclide removal to the maximum extent practical. Therefore, these liquids could be considered "incidental" waste provided the immobilized LAW qualify for disposal in a shallow land disposal facility under DOE waste management requirements comparable to 10 CFR Part 61 requirements. This waste would then be disposed onsite, near surface, as LAW in accordance with the DOE and Washington State Department of Ecology (Ecology) regulations for LLW or Mixed LLW. The residual waste left in the tanks after retrieval is excluded from this determination and will be considered separately at a later time. 


\subsection{REFERENCES}

10 CFR Part 61, "Licensing Requirements for Land Disposal of Radioactive Waste," Code of Federal Regulations, as amended.

10 CFR Part 50, "Domestic Licensing of Production and Utilization Facilities," Code of Federal Regulations, as amended.

40 CFR Part 141, "National Primary Drinking Water Regulations," Code of Federal Regulations, as amended.

52 FR 5992, 1987, "Definition of High-Level Radioactive Waste,' "Federal Register, Vol. 52, pp. 5992.

58 FR 12342, 1993, "States of Washington and Oregon: Denial of Petition for Rulemaking," Federal Register, Vol. 58, pp. 12342.

DOE Order 5820.2A, Radioactive Waste Management, U.S. Department of Energy, Washington, D.C.

Atomic Energy Act of 1954, 42 USC 2011 or 2114 et seq.

Bader, C. P., 1995, Tank Waste Remediation System (TWRS) Guidance for Update of the Multi-Year Program Plan (MYPP) - Supplemental Guidance for the Disposal Program, letter to Dr. A. L. Trego, President, Westinghouse Hanford Company, and Dr. W. J. Madia, Director, Pacific Northwest Laboratory, 95-PRI-073 (July 26), U.S. Department of Energy, Richland, Washington.

Barton, W. B., L. A. Gale, and M. E. Johnson, 1986, Sixteen Years of Cesium Recovery Processing at Hanford's B Plant, RHO-RE-SA-169, Rockwell, Hanford Operations.

Beard, S. J., and H. L. Caudill, 1964, Technetium Recovery and Storage at B Plant, Hanford Atomic Products Operation, Richland, Washington.

Bernero, R. M., 1989, Director Office of Nuclear Materials Safety and Safeguards, U.S. Nuclear Regulatory Commission, Washington, D.C. letter dated September 11, 1986, to A.J. Rizzo, Assistant Manager for Operations, U.S. Department of Energy, Richland, Washington.

Bernero, R. M., 1993, Director Office of Nuclear Materials Safety and Safeguards, U.S. Nuclear Regulatory Commission memorandum (March 2, 1993) to J. Lytle, Deputy Assistant Secretary for Waste Operations, Office of Waste Management, Environmental Restoration and Waste Management, U.S. Department of Energy, Washington, D.C. 
Boomer, K. D., S. K. Baker, A. L. Boldt, J. D. Galbraith, J. S. Garfield, C. E. Golberg, B. A. Higley, L. J. Johnson, M. J. Kupfer, R. M. Marusich, R. J. Parazin, A. N. Praga, G. W. Reddick, J. A. Reddick, E. J. Slaathaug, L. M. Swanson, T. L. Waldo, and C. E. Worcester, 1993, Tank Waste Technical Options Report, WHC-EP-0616, Rev. 0, Westinghouse Hanford Company, Richland, Washington.

Colby, J. M., 1994, Preliminary Offsite Dose Calculations for TWRS Activities, Internal Memo to J.S. Garfield (July 27, 1994), Westinghouse Hanford Company, Richland, Washington.

Colby, S. A., 1995, No Separations Data Package for the Tank Waste Remediation System Environmental Impact Statement, Rev. 0, Westinghouse Hanford Company, Richland, Washington.

Colby, S. and C. Petersen, 1995, Inventory of Technetium 99 From Reprocessing Hanford Spent Nuclear Fuel, Internal Memo 71210-95-013, from D.J. Washenfelder to Distribution, Westinghouse Hanford Company, Richland, Washington.

DOE, 1987, Final Environmental Impact Statement for the Disposal of Hanford Defense, High-Level, Transuranic, and Tank Wastes, DOE/EIS-0113, U.S. Department of Energy, Richland, Washington.

DOE, 1988, "Final Environmental Impact Statement for the Disposal of Hanford Defense, High-Level, Transuranic, and Tank Wastes, Hanford Site, Richland Washington; Record of Decision," Federal Register, Vol. 53, No. 72, pp. 12449-12453, U.S. Department of Energy, Washington, D.C.

DOE, 1994a, Integrated Data Base Report - 1994, U.S. Spent Nuclear Fuel and Radioactive Waste Inventories, Projections, and Characteristics, DOE/RW-0006, Rev. 11, U.S. Department of Energy, Richland, Washington.

DOE, 1994b, Tritiated Wastewater Treatment and Disposal Evaluation for 1994, DOE/RL-94-77, U.S. Department of Energy, Richland, Washington.

Ecology, EPA, and DOE, 1994, Hanford Federal Facility Agreement and Consent Order, as amended, Washington State Department of Ecology, U.S. Environmental Protection Agency, and the U.S. Department of Energy, Olympia, Washington.

Grygiel, M. L., C. A. Augustine, M. A. Cahill, J. S. Garfield, M. E. Johnson, M. J. Kupfer, G. A. Meyer, and J. H. Roecker (Westinghouse Hanford Company), L. K. Holton, V. L. Hunter, M. B. Triplett (Pacific Northwest Laboratory), WHC-EP-0475, Westinghouse Hanford Company, Richland, Washington.

Herting, D. L., 1993, Effect of Tank 107-AN Caustic Addition on Radionuclide Solubilities, Internal Memo 12110-PCL93-043, Westinghouse Hanford Company, Richland, Washington. 
Herting, D. L., 1994a, Strontium Removal Study--Feed Characterization, Internal Memo 12110-PCL94-017, Westinghouse Hanford Company, Richland, Washington.

Herting D. L., 1994b, Strontium Removal by Precipitation, Internal Memo 12110-PCL94-026, Westinghouse Hanford Company, Richland, Washington.

Higley, B. A., 1995, Glass Melter System Technologies for Vitrification of High-SodiumContent, Low-Level, Radioactive, Liquid Wastes -- Phase 1: SBS Demonstration with Simulated Low-Level Waste -- Final Test Report, WHC-SD-WM-VI-024, Rev.0, Westinghouse Hanford Company, Richland, Washington.

Kirk-Othmer, 1982, Encyclopedia of Chemical Technology, Third Edition, vol. 20, John Willey \& Sons, New York, New York.

Kupfer, M. J., 1996, Interim Report on Determining Best Basis Total Chemical and Radionuclide Inventories in Hanford Site Tank Wastes, WHC-SD-WM-TI-740, Draft, Westinghouse Hanford Company, Richland, Washington.

Langowski, M. H., J. G. Darab, and P. A. Smith, 1995, Volatility Literature of Iodine, Strontium, Cesium, Technetium, Rhenium and Chlorine; Technetium and Rhenium Volatility Testing, DRAFT DOCUMENT, C95-02-03E, Pacific Northwest Laboratories, Richland, Washington.

Lee, D. D., J. R. Travis, and M. R. Gibson, 1996, Hot Demonstration of Proposed Commercial Cesium Removal Technology, DRAFT DOCUMENT, ORNL/TM-13169, Oak Ridge National Laboratory, Oak Ridge, Tennessee.

Low-Level Radioactive Waste Policy Act, 1980, 42 USC 2021b et seq.

Mann, F. M., C. R. Eiholzer, N. W. Kline, B. P. McGrail, and M. G. Piepho, 1995, Impacts of Disposal System Design Options on Low-Level Glass Waste Disposal System Performance, WHC-EP-0810, Westinghouse Hanford Company, Richland, Washington.

Nuclear Waste Policy Act of 1982, 42 USC 10101 et seq.

Orme, R. M., 1994, TWRS Process Flowsheet, WHC-SD-WM-TI-613, Revision 0, Westinghouse Hanford Company, Richland, Washington.

Orme, R. M., 1995, TWRS Process Flowsheet, WHC-SD-WM-TI-613, Revision 1, Westinghouse Hanford Company, Richland, Washington.

Resource Conservation and Recovery Act of 1976, 42 USC 6901 et seq. 
Rizzo, A. J., 1989, Assistant Manager for Operation, U.S. Department of Energy, Richland Operations Office memorandum (March 6), to R.M. Bernero, Director Office of Nuclear Materials Safety and Safeguards, U.S. Nuclear Regulatory Commission.

Schroeder, N. C., S. Radzinski, J. Ball, K. Ashley, S. L. Cobb, B. Cutrell, J. M. Adams, C. Johnson, and G. D. Whitener, Macalester College, 1995, Technetium Partitioning for the Hanford Tank Waste Remediation System: Anion Exchange Studies for Partitioning Technetium from Synthetic DSSF and DSS Simulants and Actual Hanford Wastes (101-SY and 103-SY) Using Reillex-HPQ Resin, LA-UR-95-4440, Los Alamos National Laboratory.

Schulz, W. W., 1980, Removal of Radionuclides from Hanford Defense Waste Solutions, RHO-SA-51, Rockwell Hanford Operations, Richland, Washington.

Schulz, W. W., M. M. McKeon, and M. J. Kupfer, 1995, In-Tank Processes for Destruction of Organic Complexants and Removal of Selected Radionuclide, WHC-SD-WM-ES-321, Revision 0, Westinghouse Hanford Company, Richland, Washington.

Slaathaug, E. J., 1995, Tri-Party Agreement Alternative Engineering Data Package for the Tank Waste Remediation System Environmental Impact Statement, Rev. 0, Westinghouse Hanford Company, Richland, Washington.

Slaathaug, E. J., W. A. Peiffer, and K. D. Boomer, 1995, Determine Waste Separations Process Trade Study, WHC-SD-WM-ES-356, Revision 0, Westinghouse Hanford Company, Richland, Washington.

Slaathaug, E. J., 1996a, Tank Waste Remediation System Optimized Processing Strategy with an Altered Treatment Scheme, WHC-SD-WM-TI-737, Rev. 0, Westinghouse Hanford Company, Richland, Washington.

Slaathaug, E. J., 1996b, Creation of and Results From the Retrieval Sequence Optimized for Cesium Recovery (Case 101), Internal Memo 74A20-96-003, to M. E. Johnson, Westinghouse Hanford Company, Richland, Washington.

Shelton, L. W., 1995, Radionuclide Inventory for Single- and Double-Shell Tanks, Internal Memo 71320-95-002, Westinghouse Hanford Company, Richland, Washington.

Swenson, J. A., 1995, Evaluation of the Impact of the Use of Crystalline Silicotitanate Ion Exchanger on High-Level Waste Glass Production, WHC letter \#9552978, to D. H. Sanders, May 31, 1995, Westinghouse Hanford Company, Richland, Washington. 
Vida, J., 1994, The Chemical Behavior of Technetium During the Treatment of High-Level Radioactive Waste, PNL-TR-497, Pacific Northwest Laboratory, Richland, Washington. A translation of selected parts of Zum Chemischen Verhalten des Technetiums bei der Behandlung des Hochradioaktiven Abfalls, (German) by J. Vida. Translated by J.R. Jewett, Westinghouse Hanford Company, Richland, Washington.

Washington, L. O., 1990, Chemical Addition to Tank 107-AN, Internal Memo 16220-PCL90-079, Westinghouse Hanford Company, Richland, Washington.

Wodrich, D., 1994, Tank Waste Remediation System Technical Strategy, Westinghouse Hanford Company, Richland, Washington. 
This page intentionally left blank. 
APPENDIX A

CORRESPONDENCE 
WHC-SD-WM-TI-699, Rev. 1

This page intentionally left blank. 


\section{APPENDIX A}

\section{CORRESPONDENCE}

This appendix contains correspondence between the U.S. Department of Energy, the Washington State Department of Ecology, and the U.S. Nuclear Regulatory Commission on the subject of LLW classification. The letters, as described below, are presented in chronological order and document the history of the Hanford Site waste classification issue.

1. November 29,1988

Bell, Michael J., Chief Regulatory Branch, Division of Low-Level Waste Management and Decommissioning, Office of Nuclear Materials Safety and Safeguards, U.S. Nuclear Regulatory Commission, Washington, D.C. to Ronald E. Gerton, Waste Management Division, U.S. Department of Energy, Richland Operations Office, Richland, WA.

The NRC provides comments on DOE's proposed approach for classifying Double-Shell Slurry Feed (DSSF). In general, the NRC staff support DOE's efforts in: (1) seeking an NRC-DOE consensus on the classification of doubleshell tank waste; (2) using the source-based concept in classifying waste as HLW or non-HLW; (3) describing the prior treatment of any "incidental" waste; and (4) documenting waste characteristics before classification. Specific comments on the classification approach indicate if DOE could demonstrate that the largest practical amount of the total site activity (expected to be 90 percent or more) attributable to "first-cycle solvent extraction" wastes had been segregated for disposal as HLW, then the NRC would view the residual as a non-HLW. This residual would not be subject to NRC licensing.

2. March 6, 1989

Rizzo, A.J., Assistant Manager for Operations, Department of Energy, Richland, Washington to R.M. Bernero, Director, Office of Nuclear Materials Safety and Safeguards, U.S. Nuclear Regulatory Commission, Washington, D.C.

The Department of Energy, Richland asks the NRC for concurrence that the DST waste planned for disposal by grouting is not HLW, and therefore not subject to NRC licensing. An overall radionuclide material balance for all Hanford Site tank wastes shows that 3 to 5 percent of the key radionuclides which entered the tanks will be disposed of as LLW when the DST wastes are grouted. To meet the NRC criteria of segregating the largest practical amount of activity, DOE also proposes to remove 95 percent of the Cs- 137 from the complexant concentrate waste for disposal as HLW. The additional radionuclide removal would reduce the 3 to 5 percent material balance to 2 to 3 percent. The incorporation of ${ }^{137} \mathrm{Cs}$, ${ }^{90} \mathrm{Sr}$ and TRU into grout would result in radionuclide concentrations comparable to or below Class C (10 CFR 61) 
LLW and Class A for ${ }^{14} \mathrm{C}$ and ${ }^{129} \mathrm{I}$ without additional removals. Removal of ${ }^{99} \mathrm{Tc}$ was considered not to be practical or cost effective.

3. September 26,1989

Bernero, R.M., Director, Office of Nuclear Materials Safety and Safeguards, U.S. Nuclear Regulatory Commission, Washington, D.C. to A.J. Rizzo, Assistant Manager for Operations, Department of Energy, Richland, Washington.

The NRC agrees that the grout facility for disposal of DST waste would not be subject to NRC licensing. However, the NRC also states that their position on DST waste does not reflect a decision on SST waste, and they will defer judgement on the classification of SST waste until after DOE has completed its waste characterization program.

4. November 17,1989

Gregoire, C.O., Director, Department of Ecology, State of Washington to K.M. Carr, Chairman, U.S. Nuclear Regulatory Commission, Washington, D.C.

The Washington Department of Ecology notifies the NRC that the state of Washington intends to petition the NRC for rulemaking concerning the classification of high-level and "incidental" wastes.

5. January 2, 1990

Husseman, T., Assistant Director, Waste Management, Department of Ecology, State of Washington to S.J. Chilk, Secretary, U.S. Nuclear Regulatory Commission, Washington, D.C.

The state of Washington transmits their petition for rulemaking regarding the classification of HLW at the Hanford Site. The state of Washington asks that the NRC revise the definition of HLW to establish a procedural framework for determining whether certain Hanford Site wastes are HLW or not.

6. December 17,1990

55 FR 51732, "Definition of the Term "High-Level Radioactive Waste,'" Federal Register.

The above petition for rulemaking regarding the classification of HLW at the Hanford Site is published in the Federal Register.

7. March 2, 1993

Bernero, R.M., Director, Office of Nuclear Materials Safety and Safeguards, U.S. Nuclear Regulatory Commission, Washington, D.C. to J. Lytle, Deputy Assistant Secretary for Waste Operations, Office of Waste Management, Environmental Restoration and Waste Management, U.S. Department of Energy, Washington, D.C. 
The NRC denies the petition for rulemaking submitted by the state of Washington. It is believed the principles for waste classification are well established and can be applied on a case-by-case basis without revision to the regulations. The NRC states that disposal of DST waste would not be subject to NRC licensing based on the assurance that DOE would segregate the largest practical amount of the total site activity for disposal as HLW, leaving behind only a small fraction of moderately radioactive material which would be regarded as "incidental" waste.

8. March 4, 1993

58 FR 12342, Docket No. PRM-60-4, "States of Washington and Oregon: Denial of Petition for Rulemaking, "Federal Register.

The above petition denial for rulemaking is published in the Federal Register. In the denial text, the NRC refers to information presented in the March 6, 1989 letter from DOE to the NRC (see Item 2 above) and states: "The concentrations of radionuclides in the grout would be comparable to Class $\mathrm{C}$ for cesium and transuranic wastes, and to Class A or B for the remainder." The NRC understood this statement to connote that cesium-137 and transuranic radionuclides in the residual waste would be less than the concentration limits for Class C low-level waste, as defined in the NRC's requirements in $10 \mathrm{CFR}$ Part 61, and that the concentration of other radionuclides would be less than the concentration limits for Class A or B low-level waste. 


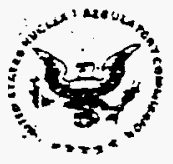

UHITED STATES

NUCLEAR FEEULATCAY COMMISSION

MAIMINOTEN, D. C. 200E:

YSV 291888

Roraid E. Gerten, Dirscior

Viata Managenent Division

U.5. Cefartiont at Enerzy

Richiand Ogeraticns QTi:

Richland, WA $g g s \leqslant 2$

Gear Mr. Gerten:

We have revtawed the proposad aporoach for elassifylng Doubia sheil siurry foed (USSF) vas:a, as presanted in the sepierter 2znd nesting on the disposal of

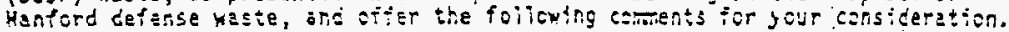

The KRe statt is in gemeral egregent with the besic eientents of its's proposed

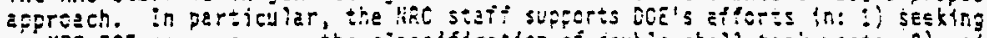
an MEC-DOE consensus on the ciassifica: icn of coltie-shell tenik waste; 2) usting

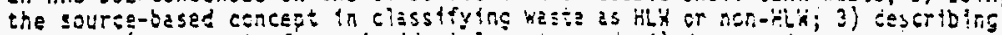

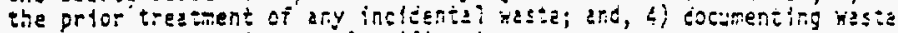
cheracteristics prior to ciassification.

Regarding the sfeclifics of the resie classiflcation approesh cescitited in your presentzition, the WRC stati cliers the foliowing somberts:

(1) The proposed zporasch statiss that indiyidual haste stregms the: cent-ibute Tess than sne percsent of tank volume would not Ee pursuled. The

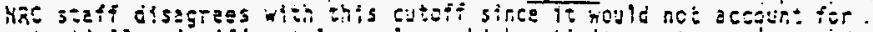

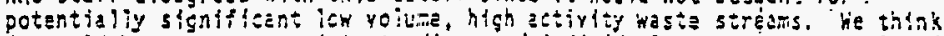

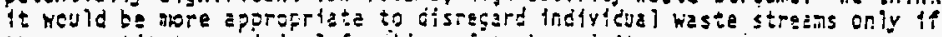

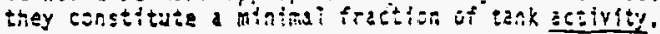

(2) OOE weuld need to provice improved sustificetion for referrtrg to a farticular xaste as "ifcilental" weste, and this justificatien sivold be consistent with the citteria proposed by kfic in our last mesting (see Enclesure).

(a) The proposed appreati irdicasas that the tharacteristics of the waste

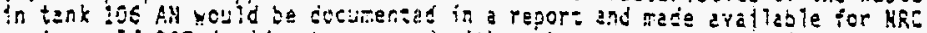
reviex. If Doe dectees to proceste with such a repcrt, it sheuld be provided for our reytex suiffcientiy in acvence so acreenent can be reached on the classification of weste before it is groutad.

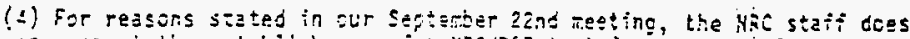

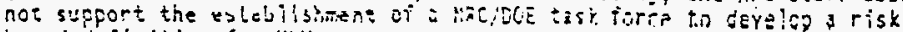
besec ceifinition for

As a more furdamental corrent on bog's proposed approch, the stati hat hoped that a determination of the classification of OSSF wase in iznk log hil might efply to the entire DSEF category. He no longer belieye that this is practicsl. Iniormation provided by doe in our vine sth meeting indicates that individual DSSf tanks centain different sultes of westes. Therefore, the

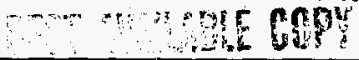


$\cdot$.

R.onde 5. Gerton $\quad$ ?

documentetion and determinaticn of wasta ciassificetitin rould rieed to oroceed on a tank-by-tank besis. Such in effort would obvicusiy requira a substantial comitment of tire and reseurces, and should be avolist if there is a mere effictent way to proceed.

Rs an alternative approsch, we suggest that DCE attegat en overall graterid balance for fill a: the Hanford st:e, using the source-besed meaning of ill $x$. It: is hoped thet this approsch rist: previde a more efficient meens of identifying those wastes subiect to liesnsing by YRC undar terms oi the 1974 Energy Recrganization Act. Under this eppreach, if bos covic cemcristrate thet the lergest practicei emeuni of the totzi site activity attributabie to "itist-cycle soivent extraction" wasies has beqn secrejalsd for disfosal as

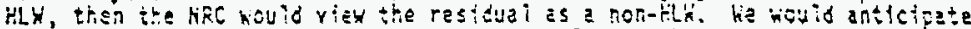

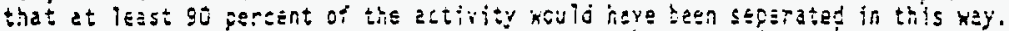

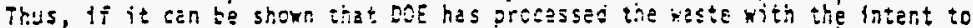
dispcse of the piL $\alpha$ in a repositery or other appropriate licensed facllity, ieaving bahind only a sma il frectica of cnly nod then the goa is states in 10 CFR Part so fopsedix $p$ and incorporated in the Energy Reorgenization Act wojid hava tesn satisfled; and the disposal of the resicual would accordingly not be sutject to liñ licensing. :

I hope that these coments are heiplui to you in resaiving the clessificablon of DSEF and other doubie-sheit tank wastes at kaniord. If you have any questions on this matter or wauld iike to arrange $3-m e c t i n g$ to diseuss the

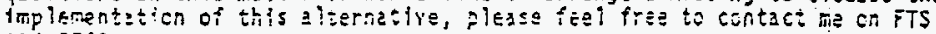
$42<-05: 0$.

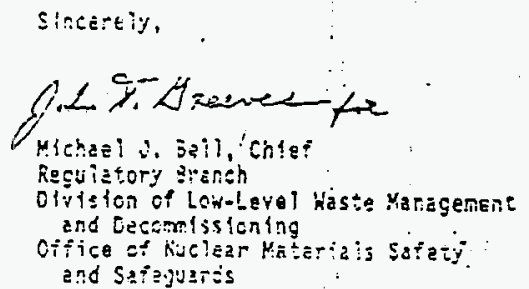

Enciusurs: Ás stat:d 


\section{SLEGESTED GRITERIA FOR GLASSIFYING OECOHTAK:NATED SALTS AS THCIOENTAL HASTES}

(1) SEFARATIOH PRCCESS YUST REPRESEHT "SOEO FAITH" EEFCET TO ACHEVE TOTAL ISOLATIOH OF HLO FRCH HOYRROICACTIVE SALTS,

- COKCEMTRATIOHS OF ROMOOHUCLICES IS SALTS SHOUID EE COHFANABLE TO CONCEMTRATICNS OF OTHER LON-LEVEL WASTES (NOT JUST EESOH THE GLASS C LIMTIS).

- TOTAL ACTIYITY CF A GROUT DISFCSAL FECHITY SHCULD EE COTPABAELE TO THAT GF OTHER ULX DISFOSAL FACILITIES.

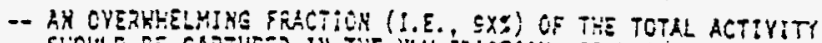
SHOLLE EE CAPTLEED IN TAE HLX FAACT:CH, SO THAT THE TOTAL IKYERTCRY OF ACTIY!TY IH GROUT DOES NOT DIFEER GREATLY FROA THE TOTAL IMVEXTCRY OF ACTIYITY AT A TYPICAL LLY OISFOSAL SITE.

(2) AS A PRACTICAL YATTER, THE "SOOD FAITH" EFFCRT YILL LIKELY HEED TO BE JUDAES SY COKSIDERIHG ALTERLATIYE SEPAFATION FROCESSES.

\section{DTP PVMPABIE COPV}



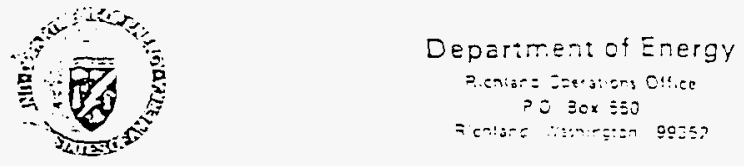

KIAR O $6 \quad 1099$

Mr. Robert M. Bernero, Director

Office of Nuclear Materials Safety and Safecuards

U. S. Nuclear Regulatory Commission

Washington, D. C. $2055 \mathrm{E}$

Dear Mr. Bernero:

Members of our stafis have seen mezing to discuss the classification and disposal of the Henford coubie-shei tank westes. The central issue is the definition of high-level waste (HLi'i, ard the application of the HLA definition in the Hanfor: Defense waste Environmental Impact statenent. Over forty-five years of بasford cpsations have resulted in numerous wasto streams, involving severai traatmen: Ectivities. This makes classification of wastes somerinat compiex. Varicus afproaches have been ciscussed in detail to resolve the classification issue. The alternate approach suggested in the November 29, 1988, ietier from Mr. Michael J. Bell of the Nuclear Regulatory Comission (:IRC) to Mr. Fenaid E. Gerton of my staff, on classifying the fraction of Hanford's double-shell tank waste planned for disposal by grouting in near-surface vaults, appears to us to be the appropriate way to proceed. This aporoach utilizes an overall material balance of tank waste at the Hanford site to demonstrate that the largest practical amount of the total site activity attributable to "first-cycle solvent extraction" wastos has been segrogated so that only the residuals will be grouted.

An overall radionuclide material balance for all Hanford tank wastes has been prepared and is enciosed. In additifon to the HLW, we have included other liquid wastes (low-level waste (LL'A) and transuranic waste) which have entered the waste tanks, however, their radionuklide contribution (in curies) is small as compared to the HL'A streans. Ih is material balance shows 3-5\% of the key radionuclides which entered the tanks with be disposed as LL in near-* surface vauts when the dcijole-shêt tarix wastes are grouted.i The concentration of radionuclides will be comparable to Class $C$ for cesium and transuranic, and to Class $\mathrm{A}$ or $B$ for the remainder. The total amount of such waste will be greater than the amount of Class $C$ waste that might be contained in a typical comaercial burial ground. It is our understanding that the NRC's concern over the anount of Class C waste is related to the possibility of intrusicn and the oegree of institutional control to be maintained. Hanford's graut disposal systen will provide excelient protection against intrusion since ite grout vaults are a solid concrete nass that will have a mutilayer enginoses barrier on top. In addition, Hanford, as a dedicated government foci ity, should heve a greater likelihcod of maintaining institutiona? controls zar reiativiy lone times.

\section{VET AMAABLE COPY}




\begin{abstract}
Sased on cansideration of alternative separaticn procasses, and to meet the suggested criteria of segregating the largest practical amount of activity, the Departiment of Energy, Richland Operations Office, proposes to remove additional radionuclides from the douole-shell tank waste for disposal as HLW. Specifically, we will remove at least: $95 \%$ of the Cs-137 from the complexant concentrate waste. This witl reduce the $3-5 \%$ material balance values to $2-3 \%$.

He believe that the data in the anciosure and jiscussed in this letter cemonstra:e that the couble-shei i ink waste pianned for disposal by grouting in near-surface vaults is not HLH, atd that whe licensing is not required. 'ue await your concurrence so that ne can proceed with this vital waste disposal progran.

If you should have any questions or corments, plezse feel free to contaci in or Mr. Renald E. Gerton of my siazi on (509) $355-136 j$.
\end{abstract}

WIMD : PKC

$$
\text { sinczreiy, }
$$

Enclosure:

Radionuclide Material Balance

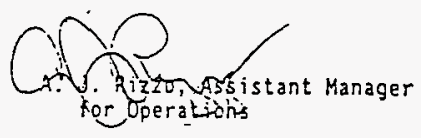


Enr?osure 1

HAHFCED TAIKK WASTE RADICHUCLIOE MATERIAL EALAUICE

\section{INTRODUCTION}

At the Hanford Site, reprocessing of irradiated nuclear fuel started in 1944. Three uranium and piutonium recovery processes have been used: bismuth phosphate, reduction-oxidation (REDOX), and plutonium-uranium extraction (PUREX).

Each of these facilities generated a source-based high-ieve? waste strean (first-cycle waste from recovery process) and several low-level waste stra $\vdots-$ : including sump wastes, miscellaneous wastes, organic trastinent wastes, and decladding wastes.

Supporting operations such as plutenium purification (Plutoniun Finishing Plant), equipment decontamination (T Plant), and on-site laboratories gen:-:: transuranic (TRU) and low-level waste. Decontamination cperations in ti.e Department of Energy's nuclear reactor (it Reactor) also produce iow-leve: waste. These low-level wastes and the treated liquids fion the frocess described below have routirely been concentrated in evaparators to reduz? the waste volume to be stored. The process condensates were discharged to ground (typically after ion exchange to remove entrained (s-137) while the concentrate is stored for later grout disposal.

The wastes are currently stored in underground single-shell (SST) and double-shell (DST) tanks. The 5STs have been removed from active liquid waste service (some residual 1 iquid is still being removed). The DST wasta inventory will be feed to the grout and vitrification disposal processas.

\section{NASTE PARTITIONING}

First-cycle waste generated prior to 1983 has gone through a combination of treatments such that the supernate of the treated waste is considered low-level waste. The treatments include neutralization/decantation, cesiun remova?, and strontium remova? (see Figure 1).

\section{Neutralization/Decantation}

All facility wastes stored in underground tanks have always been neutrai izec with sodium hydroxide to a caustic endpoint. The neutralization precipitatis the actinides and the bulk of the fission products including strontium- 90 $(5 r-90)$. The solids settle in the 75-foot diameter tanks and forn a sludge layer. Important radionuclides that are primarily soluble and remain in the a) kaline supernate are carbon-14 (C-14), technetium-99 (Tc-99), iodine-12? $(1-129)$, and cesium-137 ( $55-137)$.

The settled solids remain in the tanks when the supernate is decanted ars transferred for further pracessing. Special efforts such as sluicing or agitation with mixing pumps are required to transfer the settled solios. 
Cesium Removal

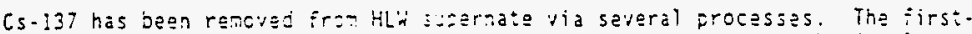

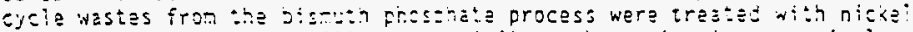

ferrocyanide in the mid-! @Eos to precipitate the cesium in some single-sinell tanks.

The alkaline supernates generated by the REDOX and PUREX plants prior to 1968 were processed in $B$ Plant for cesium removal by ion exchange. This process will also be used to remove cesium from PUREX Plant alkaline supernates generated since 1983. During the period from 1968 until the PUREX Plant shutdown in late 1971 , the acidic PUREX $P 1$ ant HLW was routed to $B$ Plant without neutralization. A phosphotungstic acid (PTA) precipitation process was then used in 3 Plant to remove the cesium.

The cesium recovered in 5 piant was purified and doubiy encapsulated for long-term storage. This cesium will be disposed in a geolcgic repository.

\section{Strontium Semoval}

As discussed previousiy, the routine neutralization/decantation of firstcycle extraction waste provides a $5 r-90$ and actinice separaticn. However, sore first-cycle extratisen wast

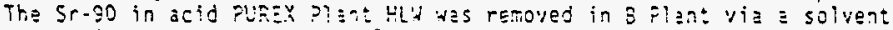
extraction process concurrentiy with the cesium PTA precipitation. Tha $B$ plant residual wastes were then neutralized and routed to the underground storage tanks.

The settled siudge produced from the neutralized PUREX Plant first-cycie extraction waste prior to 1968 was sluiced, acidified, and processed for Sr-go removal via the $B$ plant solvent extraction process.

The strontium recovered in 3 Plant was doubly encapsulated for long-term storage. This strontiuin wil also be disfosed in a joologis repository.

The PUREX Plant HL'd siudge (containing the Sr-90 and transuranic nuclices) generated since the $1 \leqq 83$ restart will be separated from the supernate. The sludge, along with Cs-137 removes from the supernats, will be incorporated into glass in the Hanford Waste Vitrification Plant (HWVP) for disposal in a seologic repository.

\section{Iransuranic Removal}

The organic complexants used in the $B$ Plant solvent exiraction process to recover strontium tend to solubilize the strontium and actinides and inhibit their precipitation. The complexent concentrate (CC) waste contains the bulk of the waste from 3 plant strontium recovery and will te treated in 3 plant with the transuranic-extraction (TRUEX) process to ransve transuranics (TRU) which will be routed to Hivp for disposal in a geologic repository.

The sludige from the PUREX Plant neutralized cladding removal waste (iiC.,N) and the solids from the Plutoniun Finishing Plant (PFP) wastes contain greater than $100 \mathrm{nCi} / \mathrm{O}$ TRU nuclices. These sludges in i also be treated in 8 Plant with the ThuEx grocess to remove ThU which in il be ruted ta Hiwp for disposal in a geologic repository.

\section{TES AMUABLE COPY}




\section{- 3 -}

\section{HANFORD \\ WASTE PARTITIONING}

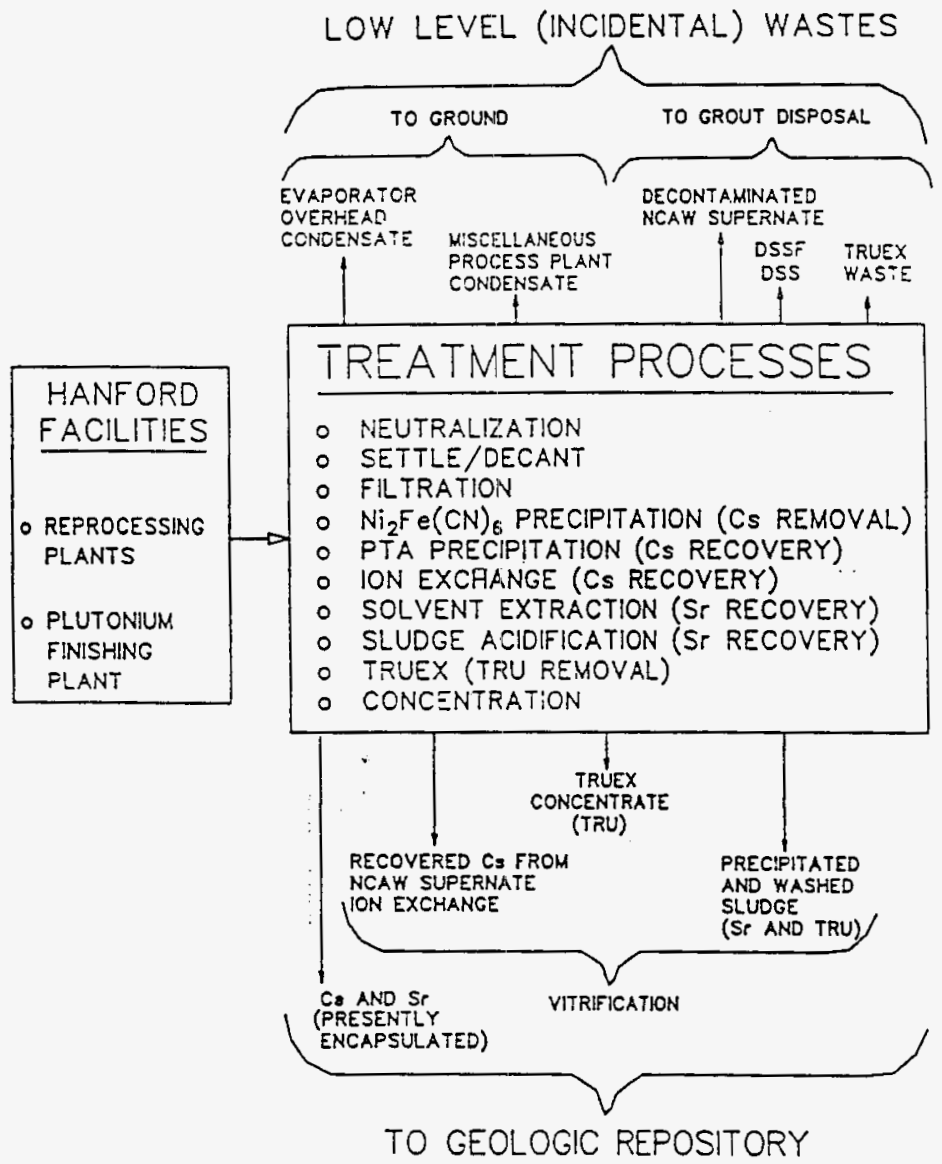

FIGURE 1 
RADIONUCLIDE MATERIAL BALAICE

The estimated percentage disposition of the Sr-s0, Cs-137, inu nuclices ano total activity from Hanford reprocessing wastes is shown in figure 2.

The bases for the radionuciode inventories used to calculate the percentages are estimates of the radionuclide inventory that entered the SST and DST wastes prior to 1983, the measured inventory in strontium and cesium capsules, and estimates of the radionuclides in wastes produced after the PUREX Plant restarted in 1983 .

The pre-1983 5ST/DST estimates are from the Hanford Defense Waste Environmentai Impact Statement (DOE/EIS-0!13) and the Hanford input to the Integrated Data Base (IDB) document for 1983 (DOE/hil-0006, Rev. 4). The IDB document was the source for the strontium/cesium capsule inventory. Both documents used the Track Radioactive Components (TPAC) Systen as the primary source for the radionuclide inventory in the Hanford tanked waste. Input data for the TRuC System were historical records of reactor, reprocessing, and waste management operations. The computer programs $2 ! 50-2$ and DCOOE were used to caiculate the radionuclides in the irradiated reactor fuel. The TRid modei then used these inputs to calculate the waste genersted by the reprocessing piants as a function of time and follow the waste through the various waste management processes and transactions to arrive at the finai waste tank inventories.

The radionuclice inventories for post-1983 wastes wera estimated using the ORIGEN-2 computer program to calculate the radionuclides in all irradiated N Reactor fuel to be reprocessed following the 1983 restart of the PUREX Plant. The PUREX Plant, waste management and planned B Plant pretreatment flowsheets were used to estimate the partitioning of the radionuclides between HLW (HWVP feed) and LL' (grout feed).

The radionuclide inventories as showr in the EIS and IOB documents are best estimates but are subject to uncertainties because of factors such as:

- incomplete/inaccurate records dating back to 1944 ;

o the use of bounding fuel impurity limits to calculate maximum activation products, i.e. C-14, since actual analyses are no longer available; and

- incomplete understanding of the chemistry and resulting pathways of some elements in the reprocessing and waste treatment processes.

Ideal\}y, actual analytical data for all Hanford tanked waste would be availabie. All grout and vitrification feeds will have such analyses before they are processed. However, only limited ana?ytical results are currently available. These analyses indicate that the total Cs-137 that may exist in grout feed could be as much as 20 million curies (ci) vice the $12-13$ million $C i$ which is the basis for the $5-6 \%$ range shown in Figure 2 . (Both of these inventories are corrected for decay to the end of $\mathrm{CY} 1995$.

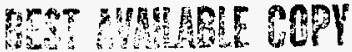




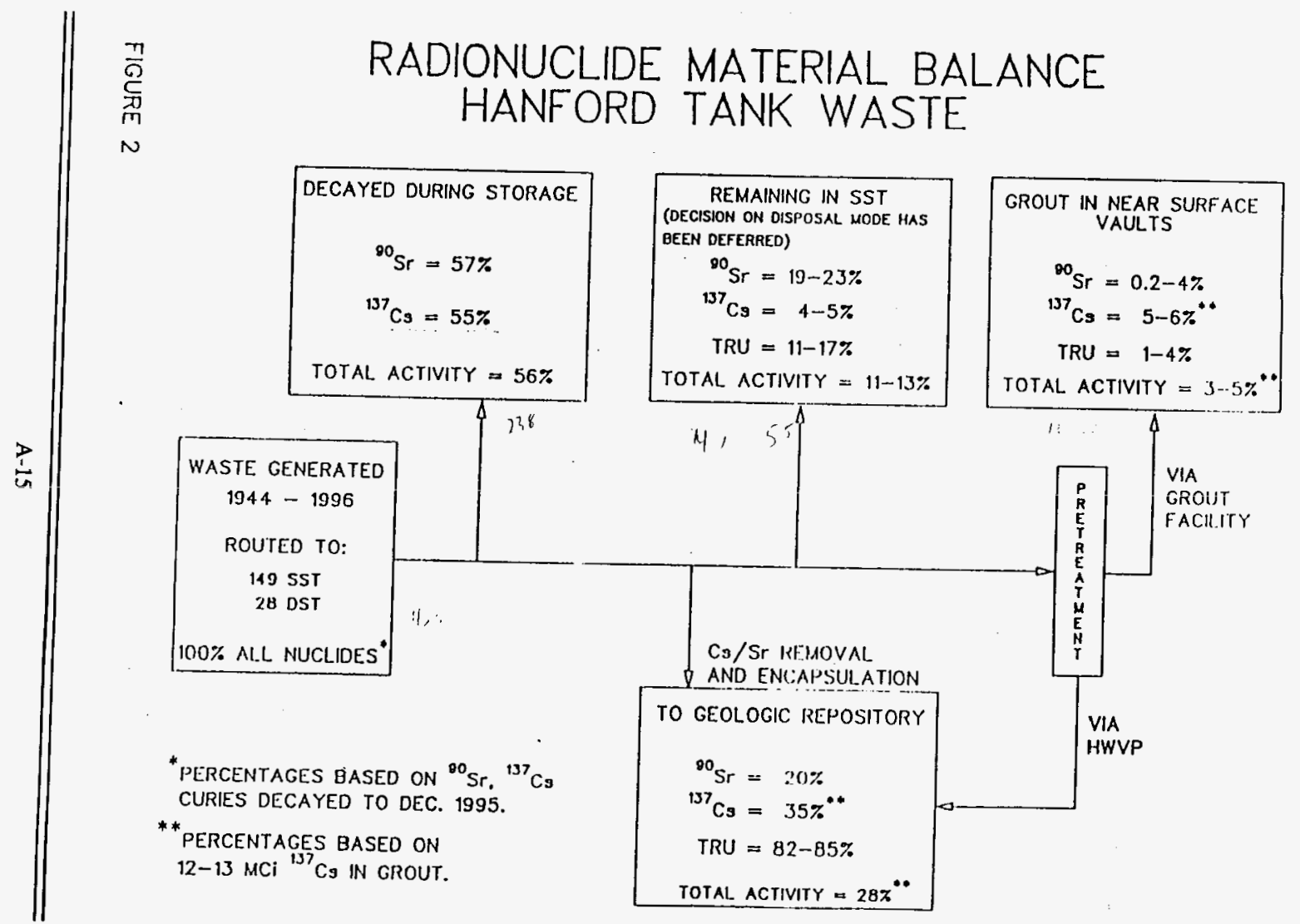


PL:AIED PRETREATMEHT OF GFCUT FEZOS

zoz

ve

ine neutraijized current acid was a (HCrin-pUREX Plant first-cjcle ex:raction was:e), the neutralized cladding removal waste (NCRW) solids, the Plutonium Finishing Plant (PFP) waste solids and complexant concentrate (CC).

The NCAW will be transferred to 3 Plant where the solids containing the $5 r-90$ and actinides will be removed and the clarified supernate ion exchanged for $\mathrm{C}_{5}+137$ removal. The washed NCAW solids and the recovered $C_{5-137}$ wili be roused to HWVP and the decontaminated sufernate stored for grout feed.

The :ICRW and PFP solids are TRU wastes. These solids will be transferred to 8 ; ant, dissolved in acid and then trested using the TRUEX extraction process. ine YRU concentrate from the TRUEY prosess and any undissolved solids will be roused to Hily.

Scme stored complexant concentrate is Tru waste. Present plans are to treat al $i$ the CC in 3 Plant for complexant destructicn and then TRU rejoyal by the TE:EX process. The TRU concentrate and any undissolved solids will be routed to fivp. These plans may be nodjfied if further characterizatizn deternines some of the wastes are non-TRJ or that comolexant desiruction is nct required.

The non-TRU wastes from the above pretreatment processes are considered to be suitabie LLW grout feeds. Waste solids would be routed directly to a grout feed tank while the supernates may be further concentrated.

No additional treatment is planned for double-shell slurry feeds (DSSF) - . The DSSF is produced by evaporation of the dilute Hanford LLW; e.g. NCRW supernate, PFP supernate, PUREX and B Plant niscallaneous wastes, pretreatment wastes and S5T resicuai liquids.

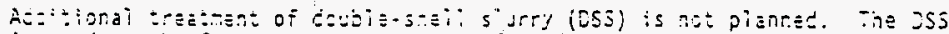
is prouuced by further concentration of DSSF past the sodium aluminate phase boundary. This stored waste contains solids and dilution/dissolution will be reguired for retrieval.

\section{POTENTIAL ADOITIONAL RADIONUCLIDE REMOYAL}

Es:imated curies disposed to grout for key radionuclides are shown in Tajie i. The incorporation of these nuclides into grout would result in radionuclide concentrations comparable to or below.Class C (10 CFR 61) LLW.

The estimated concentrations of $C-14$ and $1-129$ in the grout would be comparable to Class A (10 CFR"6I) Timits. There is no viabla technology available to further remove these nuclides from the large volune of graut feed. As previously indiceted, the inventory of $C-14$ is probabiy overstated. The estimated maximum concentration of Tc-99 in grout feed (in the pretreated NCAW supernate) would be near or slightly above the Class A limit. Additional removal of $7 \mathrm{c}-99 \mathrm{via}$ an ion exchance process is thcoreticaliy possible. However, further removai does not apfear praciica? er cost effective. Accordingly, no pretreatment for removal of these nuclides is planned.

\section{PEST AVALAABLE COPY}


Transuranic wastes will be pretreaied for Tal removal. The treated grou:

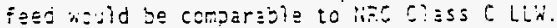

The inventories of $5 r-90$ and 65.137 deminate he estimated total activity to be disposed to grout. The inventories of these nuclides estimated for grout disposal are not significant in the Performance Assessment for grout due to their relatively short half-lives $(\mathrm{Sr}-90=28.5$ years, $\mathrm{Cs}-137=30.0$ years). The estimated maximum concentration of Sr-90 plus Cs-137 in grout would be a factor of approximately 30 below the Class C LLW limit. However, possible additional removal processes were examined to assess the practicality of further removal of these nuclides from grout feed.

The Sr-go inventory estimates are uncertain. Lut the bulk of this nuclide is in the complexant concentratz (CC) which cantains a large fraction of precipitated solids. The CC is tratiad with the TRUEX process to reduce the quentity of solids routed to - ivy? for incerpcration into glass. Aiter acidification of the CC in $S$ Plar: to dissol:s solids, complexant destruction. and TFu removal by the TRLEX prasess. the Sr-so would remain in solution. It then would be routed to grout with the finje waste. If it is necessary

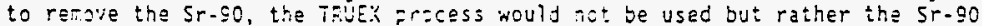
and Toj solids would be routed 2 -

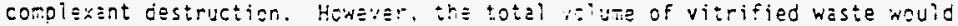

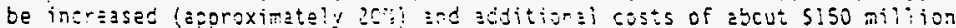

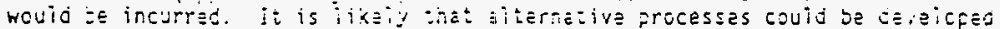
to recuce these additional volumes and costs.

Smaller quantities of Sr-SO are contained in the DSSF. The presence of low concentrations of complexant in the DSSF precludes further $5 r-90$ removal by precipitation processes. Destruction of the dilute complexant in DSSF in B Plant for $\mathrm{Sr}-90$ removal would delay the grout program by about 5 years while process equipment was designed, fabricated and installed and the initial grout ieed batch was processed. The complexant destruction would recuire approxinately four years of 3 ? int acaratica and increase 3 Plant end HWV

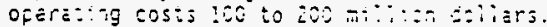

The cesium nickel ferrocyanide precipitiation process used previously in Hanford SSTs could effectively renove Cs.137 from tanked waste. However, the ferrocyanide precipitate, if routed to HWlp, could result in potential explosion hazards and metal phase production in the glass melter which would not be toleratad.

The presance of pctassium in some Hanford OSE: araciudes the use of the SRP process of cesium tetraphenyl boron precipitation since the potassium would be co-precipitated-ijth the cesium. At least iwo orders of magnitude more tetraphenyl boron (i.e., thousands of tons) would be required for treatment of the Hanford waste as comparad to the SRP waste, with the attendant problems involyed in handing this benzene compound.

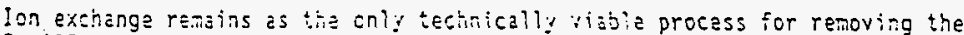
Cs.137. Use of this procass is already planned for the NCAW supernate, with startup scheduled for Jogz in B plant. The process could be used on other grout feeds, but there are tiaine and logistics probiems. If ion exchange

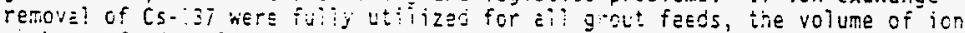
exchase feed would increaze from about seven fill ion gallons to approximatoly

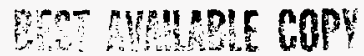


IAELL_.

ESTIMATED RADIONUCLIDES DISPOSED TO GROUT

$$
\begin{aligned}
& \text { Huclice } \\
& \hline-14 \\
& \text { Tc- } 99 \\
& 1-129 \\
& 5 r-90 * \\
& 65-137
\end{aligned}
$$

TRU

Total Activity**
MCi

MCi
0.0027
$0.016 \cdot 0.028$
$33 \times 10^{-0}$
$1-3$
$12-13$
$0.002-0.01$
$13-21$

*The Sr-90 and C5-137, curies are decayed to the end of CY 1995 * Total activity takeri as sum of $5 r-90$ pius Cs-137 since these two nuclides (and their daughier products) Jominate the total inventory. 
35 willion oallons. This increased voiume represents approximately 15 years

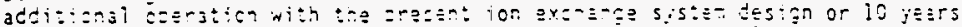

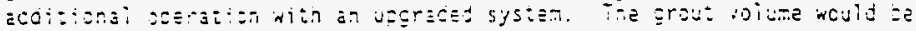
increased acout $10 \%$.

If the tanks that are now available for grout feed are held for ion exchange processing (which cannot start before 1992), the grout program would have to shut down. These tanks then would not be emptied and made availabie to store waste currently being generated. A waste storage space shortfall would result. New waste storage tanks could not be provided in time to support Hanford programs, including removal of residual liquids from SSTs and production operations.

Full ion exchange treatment of ali grout feeds weuld route approximateiy $12.8 \mathrm{MCl}$ of $\mathrm{Cs}-137$ to glass rather than grout. This would reduce the total radioactivity disposed to grout by about $51 \%$. However, Cs-137 is not the radiontelide of primary concern for the grout long-term performance assessment, and the $C_{5} \cdot 137$ removal would not significantly enhance the safety of the grout disposa? systen.

The cost for Cs-137 removal from HCAN sufernate in a Plant will be appraxiratzly $53 / \mathrm{Ci}$ (allocated operating cos:i. The est inated RCH costs (incrsmental capital plus allocated operatirg) for $(s-137,5 r-90$ remo\%a from the remaining grout feeds are as follows:

\begin{tabular}{llc} 
CS -137 Remove] & MCi Removed & $\frac{S / C i}{25-30}$ \\
\hline DSSF/OSS & $6-7$ & -8 \\
CC & -6 & \\
Sr-90 Removal & 0.25 & -800 \\
DSSF/DSS & $1-8$ & $20-150$
\end{tabular}

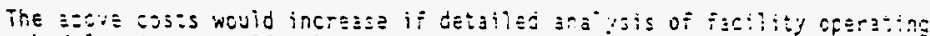
schecules (e.g., PUREX, B rlant, fiWVP) determinad that unproductive stancby time for a facility was unavoidable.

\section{CONCLUSION}

As discussed previously, delaying the grout processing of currently available feecs, i.e., DSSF/DSS, will severaly impact hancord site pregrams. Howeyer, pretreatment of the $C C$ in $B$ Plant is not scheduled to begin until $C y \quad 2000$. Thus, time is available for flowsheet development and design/installation of additional equipment as necessary to remove $C_{5}-137$ from the $C C$. The removal and vitrification of the $C_{5-137}$ from $C C$ is expected to result in 1 ass than 10 additional canisters for repository disposal, a ninimal impact. Figure 3 shows that if the approximately $5 \mathrm{MCi} C s-137$ contajned in the $\mathrm{CC}$ is removed, the percentage of $\mathrm{Cs-137}$ and total activity in the arcut wouid drop to approximately $3 \%$ and $2-3 \%$ respectively. This additional pretreatment is now being proposed.

It is concluded that with the addition of $65-13 i$ rexoval from Cc, the pianned grout iesd pretreatment represents a "cocd faith" effort to maximize isolation of HLd from Hanford site LLW. 


\section{RADIONUCLIDE NTATERIAL BALANCE HANFORD TANK WASTE}

IF ADDITIONAL ${ }^{137} \mathrm{CS}$ REMOVED FROM COMPLEXANT CONCENTRATE

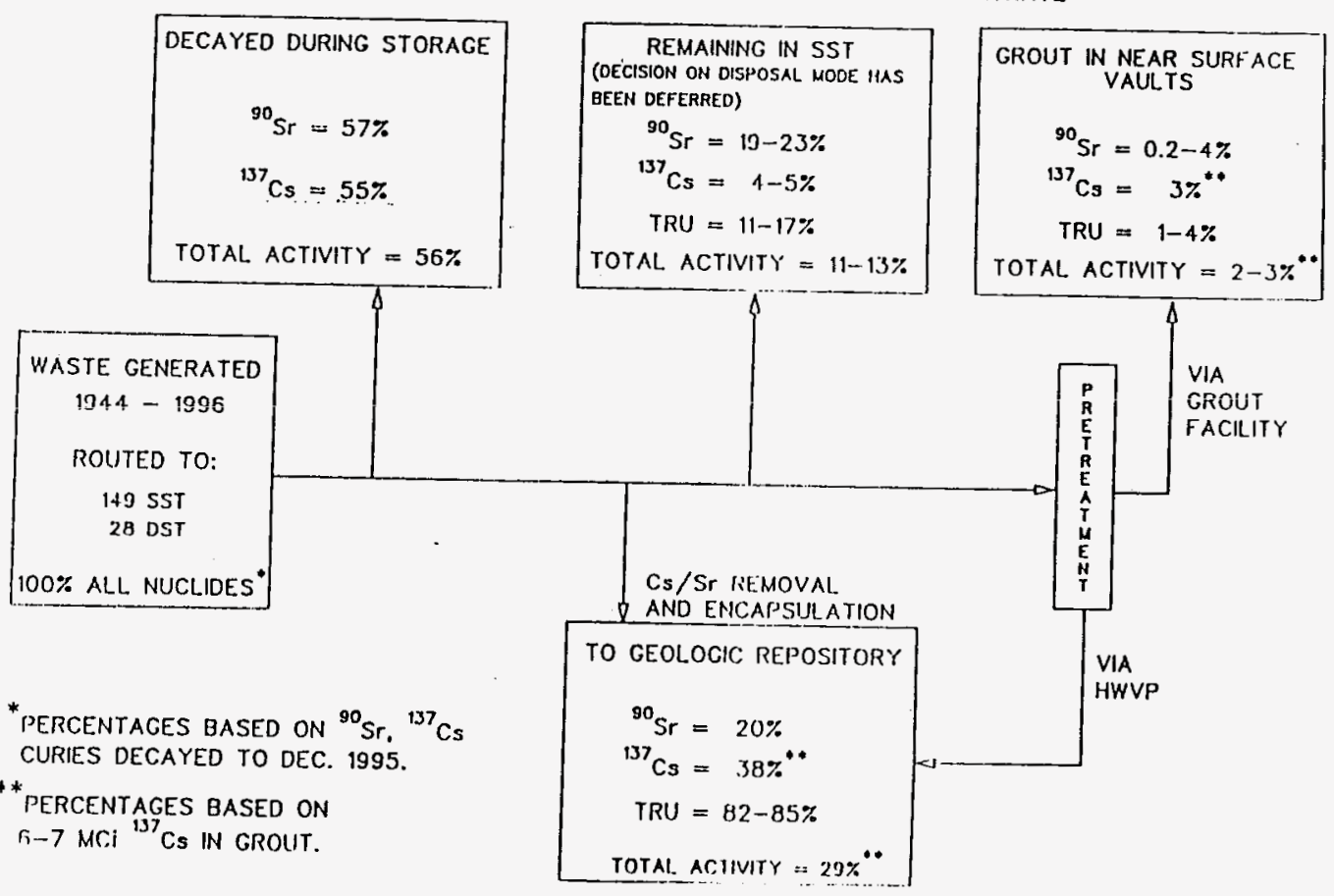



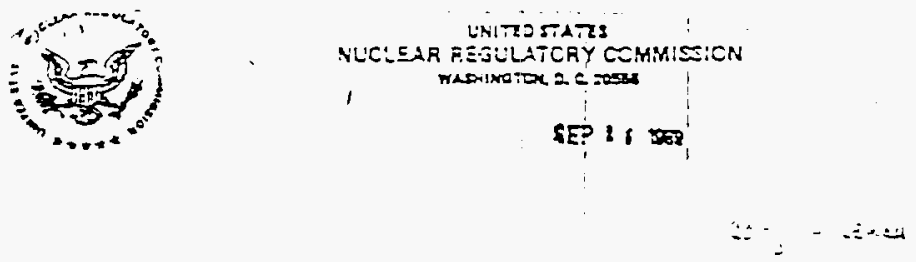

Yr. A. J. Riz=0

Assistant Manager for Cperations

U.S. Departaent of Energy

Richland Cperations ofites

P.O. Box $\equiv \equiv 0$

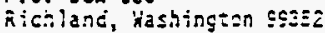

Dez: Mr. R12zo:

He have reyieyed your letter ca:es Marth 6 , tege concerning the

classification are disfosai oi the Henforj dowole-shell tank naste. Your letter anc supporting iniortatien assert that the deubie-sigeil tank wasta planned for distosel by grouting in nes-surface yaulis is nct hich-leyel

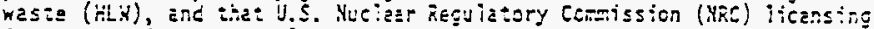
is not required. Your letes? regues is MaC concurrence in this position.

is yeu kicw, our stzits have iez on seyerzl ocsasions over the past year in an efior: to detarmine hitich of the Haniard tank wastes are procerly elassified as HLA. He consicer that the appitcable definiticn of HLit, for gurpesas of siassifying the lanicrd tank wastes, is thet set inth in 10 CER Part 50, Appendiz F. Sectificaily, HLX is defined is "those aqueeus wastes resulting from the pereration of the first cycie soivent extraction systen or equiyalent, and the concentrated waste from subseçuent extrection cycles, or equivalens, in a facility for reprecessing iriadiated reacior fue is."

The rulemaking record for Afiendia i specificaliy recegnizes a nuniser of "incidertal," nen-ill xaste streans assoctated with reprocessing plent operatiens. These incluce cladsing hulis, icn exchange wedia, siudges, and ajscailaneous trash cenerated during reprocessing operations. Not uentioned, howeyer, are wastes resulting from further processing of $H L X$ (e.g., volume resuction) or rexoving nen-radioactive saterials that yere added to the hid for feproved processing and/or storage (e.g., the addition of alkaline nderial to neytralize acidic Hill). Ai hest Yaliey and the Savannah River Piant, HAC has agreed thiat such wastes are not HLX. At hanford, the question of waste classification (and WFe licansing authority) has been capilicated by the mizing of wasta fram yarious sources over the past 45 years. This mixing has chanced the origina characteristics of the wastas and has resuited, in sore cases, in the mizing of hix and low-leve? wasta (LIX). Consequentiy, it is ncy

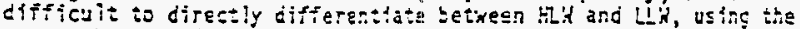
sourca-basad deifinitien sf Appencia $\bar{F}$.

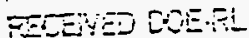

\section{CET. 2 E2}


S.. A. J. R:zzo

$\vdots \quad-2 !$

In earifer zeetings ef eur statís, critarid wers sugçested for cetergining when such wastes stouid te classifled as "incicental" yest:s rather then as Hik, and these criteria xere decunented in our leter cf

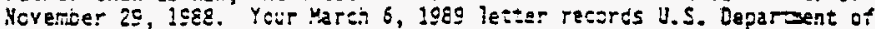
Energy's (DCE's) applicztion of thess ctiteria. Spesficaliy, your, letter proposes that tie bulk of the key radionciciodes (i.e., stentiun, cesiua and transuranics) would be separaied for etsposal in a geologic repcsitery, so that eniy thre to five percent of the original inventories of these racionucifies would te discosed by greuting in near-surface vauits. Your lettar a lso statas that the concent-ation of radtenuclices in the grout will be comparable to Class C LLA as derined by 10 CFR par: 61 for casiun and transuranles, end to Class A or $\mathbf{b}$ for the reaziner. Fina ily, your letser eye iustes the practicability and cost-a fiectireness oi acditicnal rátenucilice rasoyal. An acditional separation procass, beyond those originaliy contsmplated, was found to be cost-effective for rasoval of an additicol siz aillion euries of casium. LThis sop weild further reducs the total actirity disposed in the grout ffaclitity to two to three pereant of the inventery of HLd that originaliy entered the tanks. yoe is ncw propes ing to ferior this additional

iradionuclice rencrai ts increve the isolation of Hilt. The NRC agreas that the citteria used by oCe for classificaticn of the grout iaed as LLR are apprapriate. Thersfors, the grout facility for the dispesal of the detbie-shell tank waste woulc not be subject to our licensing authority.

Yeur letser inciea:as that tije radforucilde inventory is en estimata based on existing computar wcelels, rather then actua $i$ andyses of tank kaste. Eiven tte uncertainty in the actual racionuclide inventery, we erdorse your plans to sample and and lyze the grout feeds before disposal in an effort to entiol the final comosition of the grout feef. IIf in $i$ the coursa of condueting this samping program, you find that the Inventories of key radionuci ides entering the grout facility are s'ghificantiy higher than you now estugate, you should notify us so that the classification of the weste can be reconsidered. The XKC requests that DOE periodically subait sumearies of the analytical results of all the sampies to KRC and other arfecos parties in a timely manner.

Our position on the double-stell tank waste stould not be interpreted to rejlect a decisicn on ofsposal of sincle-sheil tank waste or to establish a precedent in any coter contaxt. We intend to cefer judghent on the ciassificition of sing?e-sheil tank waste until dfter bCE has exepieted its prosram of ciaraceriling this wasta. We anticipate that fina? socimentation will be issued for public casment before a decisten is alace on the disposal oi sirgle-sheil tank westa. 
MT. A. O. R1z:0

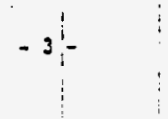

If you should have any questions or caments atcus this letter, please conzucs ze or or. Mucheel $j$. Eeii, Chief, Regulatery sranch, of ay siati at (301) $492-0500$.

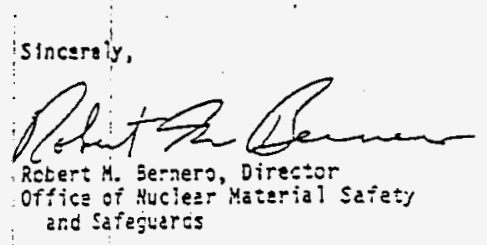

ce: Terty Husseman

Wh Departient of Esology

William ven iankea?

Yakina Indian vaticn

Jefï Breckel

Oregoninzshirgsen Liaison 
ORST O. Jicons Drenor

\author{
$(2-2)$ \\ STATE OF WASHCTION \\ DEPARTMENT OF ECOLOCY

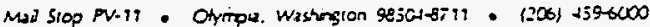 \\ November 17,1989
}

The Honorable Kenneth H. Carr

Chairman

U.S. Nuclear Regulatory Comission

Washington, D.C. 20555

Dear Chaiman Carr:

The purpose of this letter is to notify you that the state of Washington intend's to petition the U.S. Nuclear Regulatory Comission (USNRC) on a matter of great importance. Specifically, this petition for rulemaking (under subpart $H$ of 10 CFR Part 2) will addrass the USNRC's approach to the c)assification of high-ievel and "incidental" wastes. Through it, we intend to stress the need for a credible definition of "incidental" waste, one which is based on a thorough and sound techrical evaluation, and which is subjected to independent peer review and close fublic scrutiny.

This action is being prompted by a number of discussions and correspondence between our respective staff. Most recently, on August 4, 1989, Washington Department of Ecology staff met with USNRC staff to review a March 6, 1989 U.S. Departirex of Energy (USDOE) proposal concerning the classification of high-level wastes as it relates to USEOE's Hanford double-shell tanks. Following this meeting. Terry husseman of my staff summarized our major conclusions, comments, and concerns in an August 15, 1989 letter to Robert $M$. Bernero (USNRC).

$\mathrm{Hr}$. Bernero's response was containeo within ietters dated Septenter 25, 1989 to Mr. Husseman and to Mr. A.J. Rizzo of the USDOE. In summary, Mr Gernero declined any USNRC oversight role at Hanford, and changed the classification of some Hanford double-shell wastes from high-level to low-leve? waste (letters enclosed). Our request that the USRRC define its actions through publication within the federal register, and through appropriate opportunity for public comment was also denied. It is our feeling that the USNRC, as the agency responsible for the licensing of high-level radioactive waste disposal, should reconsider this action.

I want to emphasize that USDOE's nöted approach to the management of its tank wastes (March 6, 1989) is generally consistent with the terms of the Hanford Fecera? Facility Aareement and Consent Order. As such, moving ahead with the grout disposal program is essential to hanford cleanup, and care should be taien in order that this program not be delayed by legal challenges or because of a lack of public participation.

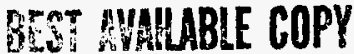


The Konorable kennein $n$. Lart

Novexber 17,1989

Page 2

We believe that issues relating to; the classification and management of these wastes, the appropriate level of USNRC involvement, and associated public participation, are too important to be implemented by letter from Comission staff.

I have consequently asked my staff to prepare appropriate petition documentation, and hope to submit it to you no later than January 1, 1990.

If you have questions or comments regarding this issue, please contact me or Mr. Terry Husseman at (206) 459-6168 and 459-5029 respectively.

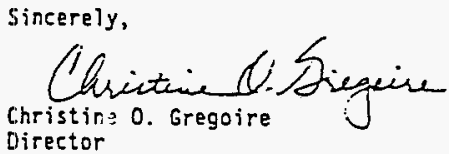

Enclosures

ce: Samuel J. Chilk

Dan Silver

Mike Lawrence

Robie Russell? 
CLRSTINE O. CRECORE Direcror

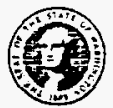 \\ STATE OF WASHNCTON \\ DEPARTMENT OF ECOLOGY \\ Mail Stop PV-11 - Olympia. Washington 98504-8711 - (206) 450-6000 \\ January 2, 1990
}

Mr. Samuel J. Chillk, Sectetary

U.S. Nuclear Regulatory Commission

Washingron, D.C. 20555

ATTENTION: Chief, Docketing and Service Branch

Dear Mr. Chille:

The purpose of this letter is to transmit to you our petition for rulemaking (under subpart $\mathrm{H}$ of 10 CFR Part 2) regarding the classifieation of high-level radioactive wastes at the U.S. Departmeat of Energy's

Hanford site. Please also refer to my November 17, 1989 notice of intent which was addressed to Chairman Kenneth M. Carr of the Commission.

Note that the enclosed petition represents the conbined views of both Washington and Oregon, and of the Yakina Indian Nation. We each look forward to working rith you and Commission staff on this very important iesue.

Sincerely,

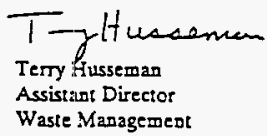

TH:kji

ce: Oregon and Washington Congressional Delegation

Dan Silver

Michael Lawrence

David Yaden

Ceell Sanchey 


\section{UNTTED STATES OF ANERICA \\ NUCLEAR REGLLATORY COMMIISSION \\ BEFORE THE COMMISSIONERS}

\section{PETIIION FOR RULEMAKING \\ $\triangle N \underline{D}$ \\ REOUEST FOR NSTTTUTION OEA RULEMARNGG PROCEEDING}

The states of Washington and Oregon, and the Yakima Indian Nation ("Petirioners") bereby respectfully request and petition the Nuclear Regulatory Commission ("the Commission") to exercise is rulemaking authority, offer adequate opporsuniv for puhlic conment, and adopt a regulation concerning classification of Hanford bigh-ievel radioactive wastes currezty stores in retrievabic, surface, storage facilities. Proceduresovertiog trestestest are found at 5 U.S.C. Section 533 and 10 C.F.R. Section 2.300-2.809.

\section{Proposed Rules}

The pectioners ask that the Commission amead to C.F.R. Part 50 to add language slarifing that all Hanford double-sbell tank wastes are bigh-level radioactive waste, unless the Commission on a tank by tank basis determines the following:

1 That the U.S. Department of Energy (USDOE) bas demonstrated that the largest tectaically achievable amount of accivity ftom each tank bas been isolated for vitrification prior to permaneat disposal.

2. That the beat produced by residual radionuclides, together with the heat of reaction during grour processing, will be within limits established to ensure that grout meets temperature requirements for long term stabiliry for low-level waste forms.

3. That any otber pretreatment processes (e.g. TRLEX) have udde:gone appropriate evaiuation by the Commission prior to implementation.

\section{Grounds 3 ind Interest}

This rulemakiog petition is based, in large part, on Section 202 of the 1974 Energy Reorganization Act, which defines Commission authority over retrievable surface storage facilities and other faciities authorized for the express purpose of subsequent long-term storage of bigh-level radicactive waste geverated by the Administration, aow Departmest of Evergy) whicb are not used for, or are part of, researeh and development activities. The grounds and interests of the state are based on the following lacts and issues:

1. The USDOE publication titled Integrared DataBase for 1988: Spent Fuel and Radioacrive Waste Inventeries. Projections, and Characteristics states that high-level waste (HLW) which is geverated by the reprocessing of speat reactor fuels and irsadiated targets, generally contains more than 99 percest of the nonvolatile fission products produced in fuel or targets during reactor operation. The $\mathrm{HLW}$ from a faciliry that recovers uranium and piutonium contains approximately 0.5 percent of ibese elements. The inventories of HLW that is in storage in the 28 Hanford double-shell tanks at the end 
Peticion for Rulemaking

Page 2

of 1987 , contained $116,000,000$ curies in $19,400,000$ gallons $(73,400$ cubic meters) of waste. Thus, it is clear that even USDOE now recognizes that the double-shell tank waste is HLW.

2 HDW was first defined in 1970 by the Alomic Energy Commission (AEC) in terms of the source of the matcrial ratber than by its hazardous characteristics. The AEC defined $H I W$ as:

"those aqueous wastes resulting from the operation of the first cycle solvent extraction system, or equivalenh and the conceotrated wastes from subsequent extraction cycles, or equivaleat in a facility for reprocessing irradiated reactor fuels."

35 Fed. Reg. 17530, 17532 Nov. 14, 1970. 10 CFR Part 50, Appendix F. This definition of HLW bas not beea cbanged and both USDOE and the Commission eurreatly utilize this definition.

3. Over the last 45 years, mixing of wastes from differeat scurces has complicated the elassification of Hanford tank wastes, including double-ste! tank wastes. Moreover, radionuclide inventories are estimates, and subject to substanial uncertainty. Variables include incomplete and inaceurate records, the lack of actual fuel and/or waste asalyses, and incomplete understanding of the chemistry and patbrays in reprocessing and waste treatment processes. Thus, neither USDOE, the Commission or the petitioners have adequate information regarding the radioactive portion of the double-shell tank waste.

4. USDOE plans to pretreat Hanford double-shell tack waste in order to partition wastes into a "bigh-level" portion for vitrification and a low-level or "incideatal" portion whict will subsequenty be disposed of at the Hanford Grout facility (currently under construction). USDOE estimates that from a minimus of $13,000,000$ curres to more than $21,000,000$ curies uri] be disposed of at the Grout facility.

5. The petitioners bave a strong vested interest in the saie, permanezt disposal of Hanford highlevel tank wastes. There is Jueat uncettaing at this time, concerning the abiliry of USDOE to demonstrate that the largest technically achievable amount of activity from each tank can be or will be isolated fot vitrification. This is evidenced by USDOE's exceptionally large uncertaincy (between 23,000,000 and 21,000,000 curies) concerning residual activity scheduled for surface disposal via grout. (Table 1 from Enclosure I of a March 6, 1989 letter from Mr. A. J. Rizzo to Mr. Robert M. Eerriero.)

6. The petitioners believe the Commiession bas the legal autho:ity and obligation to promulgate regulations concerning the elassification of Fianford taok wastes and that Commission staff are uniquely qualified to evaluate the appropriateness and effectiveness of various pretreatment processes. The rule amendment suggested above would authorize the Commission to ensure that Hanford double-sbell tank wastes be subjeet to safe and appropriate rethods of pretreatment.

7. The petitiosers bave an interest in and a prevailing responsibility for the prosection of the future health and salety of the ci:izeas of the Pacific Nortbwest. The rule ameadment suggested above is essential to provide this protection.

\section{군}


Pecilion for Rulenaking

Page 3

\section{Statement in Support}

HLW was first defined in 1970 by the Atomic Energy Commission (AEC) in terms of the source of the material rather than by its hazardous characteristies. The AEC defised HLW as:

"those aqueous wastes resulting from the operation of the first gicle solvent extraction system, or equivalent, and the concentrated wastes from subsequent excraction cycles, or equivalent in a facility for reprocessing iradiated reactor fuels."

35 Fed. Reg. 17530, 17532, Nov. 14, 1970. 10 CFR Part S0, Appendix F.

The term HIW was first used by Congess in the Martoe Protection Research and Sanctuaries Act of 1972. PL. 92.532, as amended by P.L. 93-254 (1974), codified at 33 U.S.C. Seccion 202 of ERa. See 52 Fed. Reg. 5992,5993 .

The tern HIL is not defined in the Energy Reorganization Act (ERA). The starting point in defining HLW for ERA purposes is found in existing regulations adopted by tbe Atomic Energy Commission (AEC) in 1970 . Io this regard, Congess can be presuned to bave been aware of the existing regulatory definition whea it used the term HLW in Secion 202 of ERA. The existing definition adopted by the AEC in 1970 (10 CFR Section 50, Appendix F) as noted earlier, focuses on the process by which HLW is produced to define HLW.

It is clear that defense wastes at Hadord, including double-shell taak wastes, were considered HLW when the ERA was passed. The legislative history of the ERA reveals Congress' intent at that time to subject defense facilities to NRC oversight. In fact, the Congress recognized that HLW was leaking from temporary AEC tanks at various faciliries and intended to subject such wastes to NRC licensing at the point of application of a permanent waste managemest solution. Moreover, the House Committee on Energy and Commerce found that "existing law with respect to atomic eaergy defense aetivities is unehanged by this Act, and facilities for the disposal of waste from deftase activities remain subject to licensing by the Nuclear Regulatory Commission:" H. Rep. No. 785, p1., 1, 97th Cong., 2d Sess., 38, Augu. $20,1982$.

This issue was considered in USDOE's Final EIS on defense wastes at Hanford. The Environmental Impact Statement considered various. alternative methods for dealing with these defense wastes. USDOE recognized that:

Further, Section 202 of the Energy Reorganization Act requires Commission licensing of those DOE facilities authorized for the express purpose of long-term storage of high-level radioactive waste which are not used for, or are got a part of, research and development activities. Therefore, 10 the extent that any decision based on this final EIS requires defense high-level waste to be placed in a repository constructed under the Nuclear Waste Policy Act, or a facility subject to licensing under Section 202 of the Energy Reorganization Act sucb a repository or faciliry would be subject to liceasing by the Commission.

Final Ervironmental Impact Statement, Disposal of Hanford Defense High-Level, Transuranic and Tank. Wastes, vol. 1, 6.11, December 1987.

In short, under existing law, Haniord double-sbell tank waste is HLW. A letter from the Commission eanot change tbe law. Consequeatly, long term storage or disposal of double-shell tank waste is currently

\section{BST MaALABIE COPY}


Peticion for Rulemaking

Page 4

subject to liesasing by tbe Commission. However, the nile amendroent suggested above would autherize and require appropriate Commissico oversight of tbe management of Hanford double-shel] lask wastes, but would allow, under certain ereumstances tbe avoidance of the adraitedly cumbersone licensing process.

Petitioners believe that the sule ameadenent suggested would protect bum an health and the environonent, and would facilitate meaningrul Commission involvemeat in the ultimate disposal and/or long term storage of Hanford double-shell tank waste.

PETIJONERS:

For the State of Washington

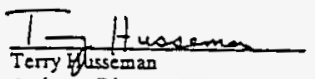

Assistant Director, Waste Management Washirgton Department of Ecology

For the Yakima Indian Nation

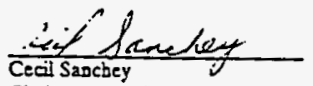

Chairman Radioactive

Hazardous Waste Commitice

Yakima lodian Nation

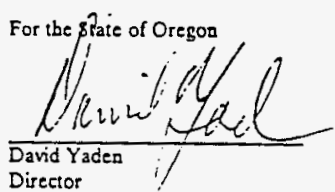

Oregon Departmeat of Energy 
Definition of Term "High-Level Radioactive Waste" NRC Docket No. PRM-60-4

55 FR 51732 
for at least 3 years, unless a longer retention time is required by part 75 of this chapter.

(2) Records that must be malntained purvuant to this part may be the original or a reproduced copy or a microform if such reproduced copy or microform is duly authenticated by euthorized pereonnel and the microform is capable of producing a clear and legible copy after torage for the period specified by Comminelon regulations. The recond may alno be stored in electronic media with the capablity for producing, on demand, legible, accurate, and complete records during the required retention period. Records such an letters, drawings, and specifications must include all pertinent informstion such as stamps, intials, and signatures.

(3) The licensee shall maintain sdequate anfeguards against tampering with and loss of records.

Dated at Rockville, Maryland, this 11th day of December 1900.

For the Nuclear Regulatory Commistion. Samual J. Chllk,

Secretory of the Commission.

[FR Doc. 60-20437 Filed 12-14-00; 8:45 am]

aume cooe rwo-o1-

\section{CFA Pert 60}

[Docket No. PAL- 60-4]

\section{Detinition of the Torm "Hah-Level} Radlonctive Weste"

Aoswcr: Nuclear Regulatory Commission.

ACtnow: Petition for rulemaking.

cumannr: The States of Washington and Oregon request that the

Commission revise the definition of the term "high-level radioactive waste" 80 as to establish a procedural framework and eubstantive stendards by which the Commisaion will determine whethrs reproceseing waste, including in particular certain waste stored at the U.S. Department of Energy's site at Hanford, Washington, is high-level radioactive waste and therelore subject to the Commission's licensing authority. oates: Submit comments by March 18 . 1991. Comments received after this date will be considered if it is practical to do so, but convideration cannot be given except as to comments received on or before this date.

Aoonessers Submit commento to: Secretary. U.S. Nuclear Regulatory Commission, Washington, DC 20555. Attention: Docketing and Service Branch. For a copy of the petition, write: Rules Review Section. Reguiatory Publications Brench. Division of
Freedom of Information and Publications Services. Office of Adminittration, U.S. Nucleer Regulatory Commisston. Washington. DC 20555.

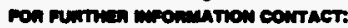
Michael T. Lead, Chlof, Rulea Reviow Section, Regulatory Publicatione Branch. Divialon of Preedom of Information and Publicetions Services, Office of Adminiotration, U.S. Nualear Regulatory Comminalon, Washington, DC 20555, Telephone: 301 492-7758 or Toll Free: 800-368-6042.

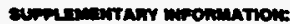

\section{Pottionen' Request}

The petitioners requeat that the Commisation amend 10 CFR 60.2 to clarify the definition of "high-level radioactive waste" (HLW) and the defindtion of "HLW facility." The petitioners request that the

\section{Commisuion-}

1. Bstabliah a process to evaluate the treatment of defense reprocessing wastee in tanks so that ouch wastes will not be considered HIWW If, prior to dipposal, each tank is treated to remove the largest technically achievable amount of radioectivity; and

2. Require that the heat produced by residual radionuclides, together with the heat of reaction during grout processing (if employed as a treatment technology). will be within limits establiahed to ensure that grout meets temperature requirements for long-term stabllity for low-level waste forms.'

The petitioners seek clarification that the disposal of wastes treated to this standard is not disposal in a "HLW facility" as presently defined in 10 CFR 60.2. The petitioners state that should the Commission regard 10 CFR Part 50 , Appendix $F$ as the controlling regulation to determine whether a waste is HIW. that the Commiseion also modify that definition as proposed in the petition.

\section{Banis for the Petition}

The petitioners atate that this rulemaking is based, in part, on section 202 of the 1974 Energy Reorganization Act, which defines Commiasion authority over retrievable surface storage facilities and other facilities authorized for the express purpose of subsequent long-term storage of highlevel radioactive waste generated by DOE which are not used for, or are part of, research and development activities. The petitioners further atate that the Congresaional definition of the term "high-level radioactive waste" in the

' Grout te \& hujd mixlure of cemenlitious materials and liquid wasle that sele up as a solio mase and is uned for woute fixation and immohilization.
Nuclear Waste Policy Act (NWPA) 42 U.S.C. 10101 (12) gives the Commiesion the authority to define whether wastes are "highly radioactive material" or "solids derived from [liquid reprocesaing wastes] that contain flasion products in sufficient concentrations."

According to the petitioners, legislative history reveals that Congress intended the Commisaion to llcense defenes reprocessing tank wastes at the point of long-term storage or dispoeal. The petitionere note that low fraction wastee resulting from pretreatment of tank wastes are acheduled to be grouted and dioposed of in land-based grout vault on the Hanford site in accordance with regulations developed under the Resource Conservetion and Recovery Act (RCRA). The petitioners believe that If such wastes are HLW, they clearly fall under the Commission's licensing jurisdiction under section 202 (1) of the Energy Reorganization Act of 1974:"

\section{Reseons for Petition}

The petitioners point out that the present definition of HLW in the Commistion's rogulations is based upon the pource of the waste. According to petitioners, while HIW may be differentiated from "incldental waste," the legal basís for doing so must derive from NWPA, apecifically $\mathbf{4 2}$ U.S.C. 10101 (12) (A), which refers to a "eufficient concentrations" criterion for classification." The petitioners claim that incidental waste source is impossible to ascertain due to mixing in defense tanks and the unavailability of accurate records. They point out, in particular. that over the last 45 years. mixing of wastes from different sources has complicated the classification of Hanford tank wastes, including doubleshell tank wastes. Moreover, the petitioners stete that radionuclide inventories are estimates end subject to substantial uncertainty. Variables contributing to the uncertainty include incomplete and inaccurate records, the lack of actual fuel and/or waste analyses, and an incomplete understanding of the chemistry and

\footnotetext{
"For an analyofe of thie provition, ome "Definition of 'High-Leval Redioactive Waste"' (advance notice of proposed rulsmaking. 52 FR G002. February 27. 1987) end eubequent rulemeking documents (proponed amendmente to $10 \mathrm{CFR}$ parl 61, $53 \mathrm{FR}$ 17700, May 18, 1500 hinal amendments to 10 CFR part 63. BA FR 22570, May 25. 196\%).

- It ahould be noted, however, that the

Commisation hes juriediction only if the fecllties are of the types deecribed in eection zoz(4).

- Note, however, the Commisuion't atstement, a1 52 FR 599s. February 27, 1967, thut clasulincation under the cited proviston "would be Irrelevent in determining whether such wasles muot be diapooed of in licenned disponel facilities.
} 
pathwaye in reprocessing and waste treatment procesues. The petitioners assert that nelther DOE, the Commistion, nor the pettioners heve adequate information regarding the radioactive portion of the double-shell unk waste. The potitioners believe that the Commistion needs to establich both a procedure and atandard for making an evaluation as to whether waste are HLW on a tank-by-tank basis.

The petitoners essert that the proposed amendment is essential to provide protection of the future heslth and safety of the citizens of the Pacific Northwest.

\section{Petitipaers' Propoeal}

The petitioners auggest that the definitions of "High-Level Rediosctive Waste" and "HILW Facility" in 10 CFR 60.2 be revised and a new appendix $A$ be added to 10 CFR part 60 . The opecific language suggeated by the petitioners reads as follows:

1. In 860.2 , the definitions of "HighLevel Radioactive Waste" and "HLW Facility" are revised to read as follows:

$\$ 60.2$ Definitions.

High-level rodioactive waste , $\mathrm{H} H \mathrm{HLW}$ means: (1) Irradiated reactor fivd, (2) Liquid wastes resulting from the operation of the firat cycle colvent extraction system, or equivalent, and the concentrated wastes from subsequent extraction cycles, or equivalent, in a facility for reprocessing irradiated reactor fuel. and (3) Solids into which such liquid wastes have been converted; provided that if, prior to disposal. defense reprocessing tank wastes are treated to remove the largest technically achievable amount of radioactivity on a tank-by-tank basis (as provided in appendix $A$ ), the treated residual fraction shall be considered an incidental waste and therefore not HLW.

$H L W$ facility means a facility subject to the licensing and related regulatory authority of the Commission purauant to oections 202(3) and 202(4) of the Energy Reorganization Act of 1974 (88 Stat 124). 2

$$
\text { 124). . . }
$$

\footnotetext{
2 Thene are DOE "faclities used primarily lor the recelpl and storage of high-ievel radionctive wastes renulting from activities liceneed under wuch Act (the Atomic Eneroy Act) " and "Retrievable Surface Storage Facllities and other facllities authorized for the exprests purpose of aubequent long-lerm starese of high-level radioective wastes genersited by (DOE), which are not uned for, or are part of. revenrch and development activities". Focilltian for the long-term torage or dieposal of incidents! wastes reoulting from treatment of defense reprocessing wurles are not HLW facilitiee.
}

2. A new Appendix $-A$ is added to part 60 to read as follow:

Appendix A-Procectures For Determining Largest Teahnicolly Achievable Treakment

At least one year before a tank of defenee reprocesuing wastes contsining high-level weate components ts treated. pretreated or blended prior to permanent dispoeal, DOE thall oubmit the following to the Commisulon and the affected itate and publiah in the Fodveal Regletur:

1. Date on phyaleal tharecteriatice of the waste, including denaity and pereent colids. Inorganic and organic conatituents, and ndiochemintry leso gamma energy analyaie. total slpha, total bets)

2. Volumetric dita on untreated waste, on volume changes expecled as a result of treatment, protroatment or blending activities and the expected volume of the final watte form (grout, salterote or vitrified wanto):

3. A description of the treatment processes. includtng an entimated mass balance for each process, and eatimated percent recovery for each eeparation, and concentrations of major wasto componento before and after treatment;

4. The proposed grout or aalicrete formulation, together with heat transfer calculations for the waste form; and

3. To the degree ponsible, trestment ayalem models aimilar to the altached grout syalem model ehould be ueed to present data and describe processeat.

At least aix montha thelore a tank of defense reprocesaing tank wastes contsining high-level waste components is pretreated. treated or blended prior to permanent diaposal in near-eurface or deep geologic faclisties, the Commiasion shall require a licenoe under section 202(1) of the Energy Reorganization Act. 42 U.s.C. sesz (4) unlean the Commination. on a tank-by-tank basis deternines the following:

1. The DOE has demonotrated that the largest technically achievable amount of activity from the iank will be teolated for vitrification prior to permanent disposal: and

2. That uee of permanent shallow land diaposal for the tank waste will be limited to the incidental waste partion, which is the activity remaining after the largest

technically achievable umount of activity has been removed; and

3. That the treatment, pretreatment and blending processes deacribed in the DOE submittal will achieve the stated separation and/or recovery efficiencies: and

4. That the treatment, pretreatment and blending processes described in the DOE -ubmittal are proven, cost effective, state-ofthe art processes, which are capable of removing the largest technically achievable smount of activity.

\section{Potitioners' Conclusion:}

The petitioners state that rulemaking procedures are necessary to determine the nature of the incidental, lesser radioactive fraction of wastes and that rulemaking is appropriate to establish a procedural framework and subatantive standards by which particular wastes will be asseased. The petitioners contemplate that particular determinations of how speclfic wastes will be characterized under these general standarts can be left to individual adjudicative proceedings.

The petitionere believe that the amendments suggested by their petition would protect human health and the environment, would facllitate moaningful Commission isvolvement in the ultimate dispoesl and/or long-term storage of Hanford double-ohell tank waste, and would support implementation of the Hanford Federal Facility Agreement and Consent Order.

\section{Requed for Commonts}

Commenters are invited to addreas, among other thinga, the destrability and approprlateness of (1) The proposed substantive standard ("remove the largest technically achievable amount of radioactlvity on a tank-by-tank basis"), (2) the proposed procedure for applying that standard, and (3) an amendment to 10 CFR part eo (in view of the scope defined in $10 \mathrm{CFR}$ 60.1) vio-a-vis the adoption of a new Part or amendment to some other exjating Part of NRC regulations.

Dated at Rockville. Maryland, thit 21th day of December 1000.

For the Nuclear Regulatory Comminsion. Samuel J. Chilk,

Secretary of the Commission.

[FR Doc. 90-29438 Filed 12-14-60; d:45 am]

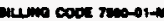

\section{DEPARTMENT OF COMMERCE}

\section{Forden-Trade Zonee Beard}

\section{CFR Part 400}

[Docket No. 21222-02a2]

RHN 0928-AMO4

\section{Forelon-Trade Zones in the Unhted} states

AOANCY: Foreign-Trade Zonea Board. International Trade Administration. Commerce.

ACrion: Notice of proposed rulemaking: extension of comment period.

summanr: In response to requests from interested parties, the period for public comment on the further amendments to the proposed revisions to the regulations of the Foreign-Trade Zones Board regarding foreign-trade zones in the United States published in the Foderal Register on November 20, 1990 [55 FR 48446), is extended to February 1, 1991. oarte: Commenta must be received on or before February 1. 1991. 


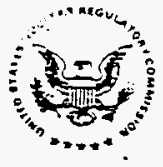

UNITED STATES

NUCLEAR TIEUULATORY COMMISSION

MASMINGTON. D. C. ZOESS

MAR $Q 2$ ISE3

Ms. Jill Lytle.

Deputy Assistant Secratary for Waste Operations

Ofice of Waste Maragement

Environmental Restoration

and Waste Management

U.S. Department of Energy

Yashington, D.C. 20585

Dear Ms. Lytle:

Kembers of the Nuclear Regulatory Comission stafi appreciated the opportunity to meet with the Departinest of Energy (DOE) staff, DOE contractors, and other parties on July 16, 1992, to review new waste characterization data and current DOE plans for management of radioactive tank waste at Hanford. The purpose of this letter is to provice DOE with the staff's assessment of that information as it relates to DOE's program to classify, process, and dispose of Haniord tank wastes. He are also taking this opportunity to respond to the related November 4, IS\$2, letter from Leo P. Ouffy to Chairman ivan Selin.

During the mesting, DOE presented revised tank waste inventory estimates, based on current characterization data. The information indicated that the double-shell tank activity that would be grouted in near-surface vaults is within earlier range estimates. The ARC stafi is concerned, however, that Cs-137 quantities are now near the upper end of the range, rather than at the lower end, as previously believed, especially given that DOE indicated that uncertainties associated with the activity estimates remain because of the limited sampling and anaiysis that has been conducted to date. Consequently, we encourage DOE to examine available mechanisms for achieving greater radionuclide separation.

In presenting its current plans for waste management, DOE outlined its intention to complete, by March 1993, a broad reevaluation of various treatment options for both single and double-shell tanks. These options include a new facility to be used to separate radionuclides for repository disposal of high-level radioactive waste (HLH).

As you recall, NRC indicated to DOE, In 1989, its agreement that the criteria DOE used for classification of grout feed as low-levei waste were appropriate, and, consequently, that the grout facility for disposal of double-shell tank 
waste would not be subject to our licensing authority (R. Bernero, NRC letter to A. Rizzo, DoE, September 25, 19e9). This agreement was predicated on our understanding that DOE would segregate the largest practical amount of the total site activity attributabie to "first-cycle solvent extraction, or equivalent" for disposai as HLH, leaving behind only a smali fraction of moderately radioactive material.

The Comission has recently completed its review of a rulemaking petition from the States of Washington and Oregon on the subject of the double-shell $\tan x$ wastes and has indicated, in the enclosed petition denial, that it would regard the residual fraction as "incidental "waste, based on the Commission's understanding that DOE will assure that the waste: (1) has been processed (or will be further processed) to renove key radionuclides to the maximum extent that is technically and economically practical; (2) will be incorporated in a solid physical form at a concentration that does not exeeed the applicable concentration limits for Class C low-level waste as set out in 10 CFR Part 61; and (3) will be managed, pursuant to the Atomic Energy Act, so that safety requirements comparabie to the performance objectives set out in 10 CFR Part 61 are satisfied.

It is therefore essential, in the light of this position, that DOE's present reevaluation of tank waste remediation options, and subsequent periodic evaluations as may be conducted, include the application of these principles. We recognize that there may be significant economic, programatic, and safety factors affecting the remediation program, but the consideration of such factors as they may relate to the possible jurisdiction of NRC should be made ciear.

If, during your periodic evaluations, it becomes apparent to you that any wastes may be subject to NRC licensing, it will be necessary for you to comunicate that concern to HRC. It will then be necessary to determine what form of pre-licensing interactions, analogous to repository site characterization, would be needed to define the appropriate disposition of these wastes. We expect that DOE will document the resuits of the anilyses supporting its conclusions and that this documentation will be adequate for an NRC review, should that be approprlate. We believe it would be prudent for any such documentation to be developed with good record-keeping and under an adequate quality assurance process.

I trust that this letter and the enclosed petition denial provide the information requested in Leo $P$. Dufify's November 4, 1992, letter to Chairman Ivan Selin, regarding KRC's intended response to the rulemaking petition by 
the States of Washington and Oregon. If you have any further questions, please feel free to contact me, at 301-504-3352, or B.J. Youngblood, Director of the Division of High-Leve? Haste Management, at 301-504-3404.

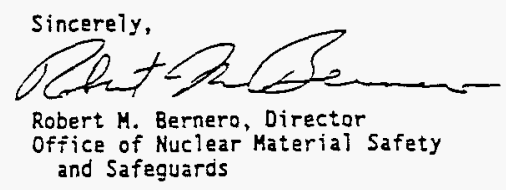

Enclosure

Petition Denia?

ce: J. Tseng, DOE-EM-35

J. Anttonen, DOE

L. Barrett, DOE-RW-1

P. Grim, DOE-EK-1

D. Duncán, EPA

R. Staniey, Washington State

J. Franco, Oregon State

R. Jim, YIN 
Duted at Rockville. Maryland, this 26th day of Fobruary 2993.

For the Nuciear Regulatory Commission. Samuel J. Cillk.

Secretary of the Commission.

IFR Doc. 93-4943 Filed 3-3-93; 8:45 2m] Wun coof rasorat

\section{CFR Fert 60}

[Dockat No. Pqu-60-4]

States of Washington and Oregon: Denial of Pethion for Rulemaking

AGencY: Nuclear Reguletory Commission.

ACnoN: Denial of petition for nlemsking.

Sumuary: The Nuclear Regulatory Commission (NRC) is denying a pelition for rulemaling (PRM-60-4), submitted by the States of Washington and Oregon. which deals with the pracess and criteris for classifying radioactive waste materials at defense facilities as high. level radiasctive waste (HLW) or as nonHLW. (As noted in the petition, certain facilities for the storage of HLW are subject to NRC licensing authority.) The petition is being denied because the NRC concludes that the principles for waste classification are well estrblisbed and can be applied on a case-by-case basis without revision to the regulations.

AODRESSES: Copies of the petition for rulemaking, the public comments roceived, and the NRC's letter to the petitioner are available for public inspection or copying in the NRC Public Document Room, $2120 \mathrm{~L}$ Stroet. NW. (Lower Level), Weshington, DC. FOR FUATHER WFORMATON CONTACT: Naiem S. Tanjous, Office of Nuclear Regulatory Rasearch, U.S. Nuclear Regulatory Commission, Washington. DC 20555, telephone (301) 492-3878.

\section{SUPPLEMENTARY WFORMUTION:}

\section{The Petition}

The States of Washington and Oregon, and the Yakima Indian Netion. initially submitted a petition for rulemaking on this subject on Jenuary 2, 1990. On Fobruary 7, 1990, the NRC staff conferred with the petitioners as contemplated by paragraph (b) of 10 CFR 2.802. In response to suggestions by the NRC staff, the petition was clarified and resubmitted (by the States of Wrslington and Oregon) on July 27 1990.

On December 17, 1990, the Nuclear Regulatory Commission published a. notice of recejpt of the petition for rulemaking (55 FR 51732). The petition requested that the Commission revise the definition of "high-level radioactive waste" (HII) so as to establisb a procedurel framework and substantive standards by which the Commission will determine whether reprocessing waste, including in perticular certain waste stored at the U.S. Deparment of Energy's (DOE) site at Hanford. Washington, is HLW and, therefore. subject to the Commission's licensing autharity.

The petitioners request that the Commission emend 10 CFR 60.2 to clerify the definition of HLW and the definition of "HLW facility." The petitioners specifically request that the Commission:

1. Establish a process to evaluate the treatment of defense reprocessing westes in tanks so that such wastes will not considered HLW if, prior to disposal, each tank is treated to remove the largest technicelly achievable emount of radiosctivity; and

2. Require that the beat produced by residusl racionuclides, together with the best of reaction during grout processing (if employed as a treatmed technology), will be within limits established to ensure that grout meets temperature requirements for long-term stability for low-level waste forms.

The potitioners state thet the potition for rulemaking is besed, in part, on Section 202 of the Energy

Reorganizotion Act of 1974 (ERA). which provides for the Commission to exercise licensing ajd related regulatory authority over "facilities authorized for the express purpose of subsequent longterm storage of high level radiosctive wastes generated by (DOE) wbich are not used for, or are part of, research and development activities."

According to the petitioners, the legislative history of the ERA reveais thet Congress intended the Commission to license defense reprocessing tank wastes at the point of long-term storage or disposal. The petitioners note that "Jow-frection wastes" resulting from pretreatment of tank wastes are

scheduled to be grouted an. dispesed of in land-based grout vaults on the Hanford site in accordance with regulations developed under the Resource Conservation and Recovery Act (RCRA). The petitioners believe that if these wostes are HLW, they clearly felt under the Commission's licensing jurisdiction under Section 202(4) of the Energy Reorganization Act of 1974 (42 U.S.C. $5842(4)$ )

The petitioners scknowledge that the present definition of HLW in the

Commission's regulations s bised upon the source of the waste, and that "incidental weste" generated in the course of reprocessing is not HLIV. (The latter point is evident from the proposal to amend 10 CFR 60.2 to provide that a residual fraction would be "considered an incidental weste and. therefore, not HLlW." The petitioners claim. bowever, thot wastes stored in tanks at Hanford cannot precticebly be classified as incidental waste las opposed to HLW) becsuse the teriks contain a mixture of wastes from a number of sources, including reprocessing of reactor huel. Moreover, the petitioners state that redionuclice inventories are estimates subject to substantial uncertainty. owing to lack of eceurate records. Further, the petitioners assert that neither DOE, the Commission, nor the petitioners have adequate information regarding the source and composition of the tank wiste. Hence, the petitioners believo that the Commission needs to establish both a procedure and a standard for making an evaluation as to whether westes are HLW on a tank-by-tank basis.

The petitioners assert that the proposed amendment is essential to provide protection of the furture health and safety of the citizens of the Pacific Northwest.

\section{Classification of DOE Reprocessing} Wastes

At Hanford and other sites, questions have arisen regarding the classification of reprocessing w'astes for which DOE must provide disposel. In the long. standing view of the Commission. these questions must be resolved by examining the source of the wistes in question. The reason for this is that when Congress assigned to NRC the licensing authority over certain DOE facilities for "high-level sadioactive wastes." the Congress was relerting to those materials encompassed within the meaning of the term "high-level redioactive waste" in A ppendix $F$ of 10 CFR Part 30. IFor a full statement of this position, see the discussion presented in the Commission's advence notice of proposed rulemaking. "Definition of High-Level Radionctive Weste" (52 FR 5993. Fabruary 27, 1987). Accordingly, eny facility to be used for the disposal of "those aqueous wastes resulting from the operation of the first cycle soivent extraction system, or equivalent. ." as HLW is defined in Appendix $F$ to Part 50, must be licensed by the NRC. Most of the waste siorage tanks at Savanneh River (South Carolins). West Valley (New York), end Hanford contain wiastes that met this definition, and the facilities to be used for disposal of these wastes are, therefore. potentially subject to NRC Jicensing jurisdiction. 
However, when the Appendix F definition wes promulgated, the Atomic Energy Commission specifically noled thet the term HLW did not include "incidental" waste resulting from reprocessing plent operations, such as ion exchange beds, sludges, and contaminated laboratory items, such as clothing, tools, and equipment. Neither were radioactive hulls and other irradiated and contaminated fuel structural hardware encompassed by the $A$ ppendix $F$ definition. Undar the sems reasoning, as the Commission has previausly indicated. incidental wastes generated in further treatment of HLW (0.8., salt residues or miscellaneous trash from waste glass processing) would be outside the Appendix $F$ definition.

In the cases of Savannah River and West Valley wastes, DOE plans to retrieve the wastes from their storege tanks and to separate essentially all of the radioective materials for eventual disposal in a deep-geologic HLW repository. ${ }^{1}$ Accordingly, the projected recovery of HLW from the wastes in tank storage at those sites will be suificiently complete that the decontaminated salts and other residua! wastes are classified as "incidental" (i.e., non-HLW). The NRC will have no regulatory authority, under Section 202 of the Energy Reorganization Act, over DOE's facilities to be used for processing and disposal of the incidental wasto.

At Hanford, DOE plans to process the wastes presently stored in double-shell tanks in a manner similar to thet planned for the wastes at Savannah River and West Valley. Such processing would separate most of the redioactive constituents of the wastes for eventual deep-geologic repository disposal and. the residual salts would be disposed of onsite in a shallow, near-surface concreto-like grout facility. (Plans for processing of single-shell tank wastes have been deferted.) However. classification of the Hanford doubleshell lank wastes has proven more difficult than classification of Savannah River and West Valley wastes. At Hanford, many of the primery reprocessing wastes were generated using older separation technologies,

\footnotetext{
I See 52 FR 5992, Fobrungy 27, 1087 (definilion of "high-level wasto"), n. 1, where the Commlasion chareclerizes as "incidentel wasle," the

decontaminaled ealt with residual activilios on the order of $1,300 \mathrm{nCl} / \mathrm{g} \mathrm{Cl}-137,30 \mathrm{nCl} / \mathrm{s} \mathrm{Sr}-90,2 \mathrm{nCj} /$ 8 Pu, al doscribed in the Departmenl of Energy's FES on Jong-torm mamegement of defenee HLW al the Savanah River PlanI, DOEJEIS-0023. 1979. Althoigh an EiS has not yol beon published for the West Valiey Demonstration Proioci, preliminary estimales indicale tho likelihood of an equivalant
} tegrte uil separntion. which resulted in substantial dilution of those wastes with nonradioective materials. In addition, many of the tanks at Henford contain mixtures of wastes from both reprocessing sources and other sources. Finally, recordkeeping at Hanford was not always thorough onough to allow precise determinations of the origins of the wastes now present in specific tanks at Hanford. For these reasons, some of the Hanford tank wastes cannot be readily classified as either HLW or incidental wastes using only the definitions and concepts discussed above.

Taking into account these uncertainties and their implications with respect to NRC jurisdiction, the NRC and DOE staff held several meetings to explore the situation in detail. A principal objective of these meetings was to ascertain, to the extent practicable, whether some or ail of the wastes should be regarded as HLW and whether, on the other hand, some or all of the wastes should be classified as non-HLW. Several things became clear as a result of these meotings.

First, manegement records were adequate for DOE to determine that two double-shell waste tanks do not contain wastes from reprocessing of reactor fuels. Therefore, these wastes clearly do not contain HLW within the Appendix F definition. The NRC agreed with DOE that any disposal facility intended exclusively for these wastes would not be subject to NRC licensing authority.

Second, DOE has carried out a "material balance" analysis of waste management activities at Hanford. This analysis estimeted the total amount of "first cycle reprocessing wastes" generated at Hanford and, to the extent practicel, the current location of those wastes. The DOE proposed onsite grout disposal of the residual wasto from the double-shell tank waste processing would be only small fraction of the reprocessing wastes originally generated at the site.

Finally, DOE studied possible technologies for adiditional waste processing. and agreed to remove the largest practical amount of radioactive material from double-shell tank wastes prior to disposal in onsite grout facilities. This commitment by DOE. coupled with the matorial-balance study indicating that most of the originallygeneraied radioactive material would be recovered, led the NRC staff to conclude that the residual waste material should be classified as incitental waste, since they are wastes incidental to the process of rucovering HLW. With this classification, DOE could proceed with onsite disposal of such incidental wastes in a grout facility without licensing by the NRC. It should be noted that if the DOE processing operations go as planned, the residual activity of these incidental wastes would be below the concentration limits for Class $C$ wastes under the waste classification criteria of 10 CFR part 61.

Following its review, the NRC staff, by letter dated Soptember 25, 1989, from R.M. Bernero, Director, Office of Nuciear Material Safety and Safeguards, NRC, to A.J. Rizzo, Assistant Manager for Operations, Richland Operations Office, DOE, endorsed DOE's plans to sample and anslyze the grout fends before disposel in en effort to control the final composition of the grout feed. However, the staff indicated that if DOE were to find, in the course of conducting the sampling program, that the inventories of key radionuclides entering the grout facility are significantly higher than previously estimated. DOE should notify the NRC and other effected parties in a timely manner.

It should be noted that the appropriate classification of some Hanford wastes remains to be determined-apecifically, any single. shell tank wastes, and any empty but still contaminated waste tanks DOE might dispose of in-place. For both types of wastes, a cese-by-case determination of the appropriate waste classification might be necessary.

\section{Discusuion}

The petition for rulemaking presents two basic issues. The question is not whether "high-level waste" should be interpreted by reference to the sourcebased concepts derived from appendix $F$ to 10 CFR part 50. The petitioners agree that this is proper. Nor is there any fundamental challenge to the concept that "incidental wastes" are excluded from the definition of "high-level waste." The issues are much narrower ones. The first issue is a substantive one-the criterio to be applied in differentiating incidental waste from high-level waste. The second issue is a procedural one-the process that should be employed by the Commission in arriving at a judgment whether or not it has jurisdiction over particular fecilities. These will be addressed in turn.

\section{A. The Standard for Classification}

We first address the standard that should be employad in distinguishing high-level waste from incidental waste. In doing so, we strive to apply the policies that underlis the adoption of appendix $F$ to $10 \mathrm{CFR}$ part 50 (and. hence, section 202 of the Energy Reorganization ACt) 
The petitioners suggest that the proper standard, to be applied on a tank-by-tank basis, is to consider all processing strams to be high-level waste uniess they have been treated, prior to disposal, "to remove the largest technically achievable amount of redioactivity." Adoption of such a criterion would certainly serve the goal. which hed been contemplated by the Commission, of removing the hazardous process streams to a geologic repository for permanent storage. It is not the only standard. however, that would suffice for this purpose, perticularly when it is viewed in a broeder regulatory context.

The clearest expression of the overall regulatory objectives is the Atomic

Energy Commission's (AEC's) explanatory statement when it promulgated eppendix $F-$ namely, "that the public interest requires that o high degree of decontamination capability be included in such facilities and that any residual radioactive contamination after decommissioning be sufficiently low as not to represent a hazard to the public health and safety." 35 FR 17530, November 14, 1970. As we read the AEC's intent, the reference to "e high degree of decontamination capability" leaves a substantial degree of discretion. It certainly does not rule out consideration of economic factors as well es technical ones. It was the AEC's contemporaneous practice to consider financia! impacts as, for example, in controlling releases of radioactive meterials from licensed facilities to the lowest levels "technically and oconomically practical." AEC Manuel Chapter 0521. When the AEC spoke of a "high degree" of decontamination capability, we believe that it was guided by similar considerations. Moreover. from a policy standpoint, this makes good sense, for so long as there is adequate protection of public health and safoty, it would not be prudent to expend potentially vast sums without a commensurate expectation of benefit to health and the environment.

Achieving a "high degres of decontamination capability" implies, then, that the facility should separate for disposal as much of the radioactivity as possible, using processes that are technically and economically practical. In addition, however, as the AEC's statement indicates, the residual radioactive contamination should be sufficiently low as not to endanger public health and safoty.

These principles-high decontemination copability and protection of health and safety $\rightarrow$ res the ossential benchmarks thet hove influenced the development of NRC's position vis-e-vis DOE on the question of the proper clessification of the tank wastes and grout at Hanford.

When the question regarding classification of wastes was first raised, the NRC staff identified to DOE some approsches that might be used in distinguishing HLW from incidental waste. One eppronch was expreseed as follows: ${ }^{2}$

As an alternative upproech, we euggest thet DOE attempt an ovelill material belance for $H L W$ at the Hanford site, using the sourcebased meaning of HLW. It is hoped that this approach might provide a more efficlent means of identifying those wantes subject to licensing by NRC under terms of the 1974 Energy Reorganization Act. Under this approach, If DOE could demonstrate that the lagest prectical amount of the total site activity attributable to "hrst-cycle solvent extraction" wastes has been eegregated for disposal as HLW, then NRC would view the residual Bs B non-HLW. We would anticipate that at least 90 percent of the activity would heve been separated in this way. Thus, If it can be shown that DOE has processed the waste with the intent to dispose of the HLW in a repository or other appropriate licensed facility, leaving behind only a small traction of only moderately radioactive meterial, then the goals stated in 10 CFR part 50 appendix $F$ and incorporated in the Energy

Reorganization Act would have been

satisfied; and the disposal of the residual would eccordingly net be subject to NRC licensing.

In response, DOE; considered the practicality of various waste processing altematives and presented the results of its study by letter dated March 6, 1988. ${ }^{3}$ The resulte were biso presented at a meeting among interested parties, including the petitioners, held on August 4, 1989. (Minutes of the meeting are available for public inspection in the NRC Public Document Room) DOE's "baseline" disposal plans would have recovered all but about 12-13 million curies of cesium-137, together with lesser activities of strontium-90, transuranics, and other radionuclides. 4 DOE's study indicated the precticality of removing an additional 6 million curies

'Letce from Michnel f. Bell. Chitef, Regulatory Branch, Division of Low.level Wast Mansgement and Decommistoning, Office of Nucleus Maleriel Salaty and Saleguards. NRC, lo Ronald E. Gorton, Director, Wasto Menagement Diviaion, Richlend Operations Office, DOE. Novecuber 29. 1880. The lettar included some "suggested criteria" involvin "good faith" effort to achiove ieolaton of HLW from nonradionctive alls, auch an oflort to be judged, as a practical maller, by considering (cmong other thinge) diemsitive ewparation procesest. 'Letier from A. J, Rlzzo, Actisunt Manager for Operations, Richlend Operations Office, DOE, to Robert M. Bernero, Direciss, Office of Nuciear Matertabs Safety and Sefequerds. NRC, Merch $B$. 1988.

- DOE noted in the March 6. 1969 leiter from Rizzo to Barnero thet, baud on limited evalable analytical date, the total cisetism-137 could be as unch as 20 million curies versits the 12-13 miltion
eatimste. of cesium-137 for repository disposal. DOE proposed to remove this additional 6 million curies of cesium-137. DOE also identified additional treatment alternatives, with their associated costs. which it viewed as not being economically prectical. DOE's material balance showed that, after the residue from the double-shell tank wastes is grouted, 2 to 3 percent of the key radionuclides which originally entered all Hanford tanks would be disposed of as LLW in near-surface vaults. The concentrations of redionuclides in the grout would be comparable to Class $C$ for cesium and transuranic wastes, and to Class A or $B$ for the remainder. ${ }^{5}$ DOE also noted certain engineering and institutional factors that inight compensate, especially as to potential intrusion hezards, for the possibility that the total amount of waste that would be grouted would be greater than the amount of Class $\mathrm{C}$ waste that might be contained in a typical commercial burial ground.

Based on its review of DOE's March 6, 1989 submission, the NRC staff concluded that DOE's proposed processing would rernove the largest practical amount of total site activity, attributable to HLW, for disposal in a deep geologic repository. This finding was based on: (1) Past and planned treatment of the tank wastes: (2) radionuclide concentration and material belance; and (3) cost-effoctiveness of additional redionuclide removal. These conclusions reflected DOE's undertakings both to achieve a high degree of separation and to provide protection of public health and safety. As a result, the slaff concluded that the expected residual waste would not be high-level waste and would thus not be subject to NRC licensing authority. The staff thereupon advised DOE that NRC agroed that the criteria used by DOE for classification of the grout feed are appropriate and that the grout facility for the disposal of the double-shell tank waste would not be subject to NRC licensing authority. ${ }^{\circ}$

\footnotetext{
'NRC underalood this statement to connole that cosium-137 and tranuranic radianuelidas in the residuel waste would be less then the concenteven limits for Clane $C$ low-level waste, as dofined in NRC's requirements in 10 CFR Part 61 , and that the concentration of other nedionuclides would bo leas than the concentration limits for Clane A or B lowlovel waste.

- Lotter from Robert M. Bernero, Director, Onice of Nucloar Material Sefoty and Salogurds. NRC, to A. 1. Riszo. Aesietent Maneger for Operation. Richland Operations Ofice, DOE. Sopienter 25. 1889. The lotter aleo called upon DOE to advies NRC periodically of the analytical result of eanples of key radionuclides enterting the grout facility. wo that the clesesfication of the watle might be reconsidered if the inventories were signiticantly higher than DQE hed savimated.
} 
At a meeting in Richland, Washington on July 16, 1992, DOE staff presented more detailed double-shell tank waste processing options and, besed on recent analyses, summarized available information on the characteristics of waste within the tanks. DOE's current estimate of the total amount of radioactivity proposed for disposal in grout in near-surface vaults is within earlier range estimates but is now believed to be nearer the upper end of the range. DOE also clarified its intention to epply criteria comparable to the Performance Objectives set out in 10 CFR part 61. Among other things, these performance objectives include numerical radiation exposure limits for protection of the general population from releases of radioactivity and requires a design to achieve long-term stability of the disposal site.

DOE intends to complete a reassessment of the tenk waste processing options by March 1993. This reassessment, the NRC steff understands, will include a reexemination of the practicality of achieving higher degrees of separation, perticularly with respect to those tanks that contain substantial quantities of key radionuclides.

Assuming implementation of DOE's plans as described above, the Commission concludes that any radioactive material from the double shell tanks that is deposited in the grout facility would not be high-lovel radioactive waste subject to NRC's licensing jurisdiction. The responsibility for safely managing those wastes rests with the Department of Energy. The besis for the Commission's conclusion is that the reprocessing wastes disposed of in the grout facility would be "incidental" wastes because of DOE's assurances that they: (1) Have been processed (or will be further processed) to remove key radionuclides to the maximum extent that is tochnically and economically practical; (2) will be incorporated in a solid physical form et a concentration that does not exceed the applicable concentration limits for Class $C$ lowlevel waste as set out in 10 CFR part 61 . and (3) are to be managed, pursuant to the Atomic Energy Act, so that safety requirements comparable to the performance objactives set out in 10 CFR part 61 are satisfied.

The petitioners also requested that the Commission exercise oversight to assure that the grout meets temperature requirements for low-level waste forms They acknowledge that DOE's vault design is protective of human health and the environment if heat produced by residual radioactivity, together with heat generated from reactions during the grout process, is kept within defined limits. They present no technical deta to suggest that achievement of these temperature controls presents any unusual engineering challenge. In eny event, inesmuch as the Commission does not consider the grout produced in accordance with DOE's plans to be high level waste, it does not have the authority to carry out this oversight function.

\section{B. Procedural Issues}

1. Whether Rulemaking Is Necessary and Desirable

The petitioners urge that the Commission initiate rulemaking procedures that would result in the esteblishment of substantive criteria for determining whether particular radioactive wastets either are or are not high-level waste. Generally, e decision whether to proceed by rulemaking (as requested) or to make determinations in individual, ad hac litigation lies within the informed discretion of the cognixsnt administrative egency. Rulemaking is most eppropriate where an egency seeks to establish a general principle, heving prospective effect, to be applied in a wide variety of factual contexts. Where the issue belore an agency involves the application of low to a very specific existing fact situation, especially where that situation is not representetive of other matters that may need to be decided by the agency, then it is clearly more efficient and more to the point to decide by a process of adjudication (i.e., on a case-by-case basis\}.

Applying these principles to the petition at hand, the Commission has little difficulty in concluding that rulemaking is neither necessary nor desirable. Reprocessing wastes are located at only four principal locations in the United States. The Commission has praviously determined that the residual contamination anticipated from proposed operations at Sevennsh Rjver should be charectarized as incidental waste and not high-level waste (see 52 FR 5993, Feb. 27, 1987, cited above, at footnote 1.) Waster generated at the Idaho Chemical Processing Plant are markediy different: from those at Hanford and Savennah. Therefore, if questions about classification of the Idaho wastes should arise, precedents established at Sevannah River and Hanford might be difficult to opply. Any wastes at the Western New York Nuclear Service Center will require treatment in accordance with the applicable provisions of the West Valley Demonstration Project Act.
The limited prectical offect of the decision-i.e., restricted to the Hanford tanks - is reeson enough to proceed by way of adjudication instesd of rulomaking. The Commission is persuaded further by the need to avoid making premature decisions with respect to the wastes stored at Hanford in single-shell tanks that are not the subject of pending treatment plans. If the Commission were to establish rules to apply to the wastes remeining in those tanks, our inquiry would have to be greatly broadened; and it might become necessary to consider a wide range of situatione that might or might not ever come to pass in the future.

2. Whether the Commission Is Adequately informed

Petitioners suggest that their proposed procedures, which include detailed tank-by-tank assessments, are necessary to ensure confidence in the treetment process employed by DOE and to build confidence that the treatment standard is being met.

The issue to be decided by the Commission is a much narrower one: it is merely to determine whether the activities being undertaken by the Depertment of Energy foll within the NRC's statutory jurisdiction. As in the cese of other persons whose activities may fall within our regulatory sphere. the Commission may from time to time demsnd information so as to be eble to determine whether or not to initiate an enforcement action. The NRC ataff has octed in this manner in its inquiries to DOE, It has obtained and evaluated information that is relevant and material to a determination whather or not the proposed activities of the DOE ere subject to NRC licensing juriadiction. All the information obtained and evaluated has been made available contemporaneously to the public.

Moroover, as a practical matter. NRC recognized the uncertainties associated with the projected redionuclide inventories in the tenk wastes and endorsed DOE plans for sampling and snalyzing the grout feeds before dispossl. The objective of these efforts is to control the final composition of the grout wastes. If DOE finds that it can no longer assure that these wastes will be managed in accordance with the criteria previously discussed, DOE should notify NRC

If a standard of "largest technically achievable amount * " will be isolated" were to be applied, then the facts submitted by DOE might not be sufficient to conclude that NRC lacked jurisdiction. However, the proper standard includes considerations of rionomical practicality as well. As 
indicated in an earlier part of this decisien, the Commission hes obtained intormstion that is sufficient for this purpose.

3. Future Adjudications

The petitioners contemplate thet if rule were to be adopted in accordance with their proposel, particular determinations of how specific wastes would be characterized would be "left to individusl adjudicative proceedings." The NRC infers that the "proceedings" contemplated by petitioners are licensing activitios of the kinds specified in Section 189 of the Atomic Energy Act, as amended, 42 U.S.C. 2239. Adjudications in this type of proceeding are in some cases to be conducted in eccordance with the hearing provisions of subpart $L$ of 10 CFR part 2 .

These procedures are often appropriate with respect to activities that are subject to NRC regulatory and licensing authority. However, the NRC is reluctant 10 employ them in the context that is proposed-to determine whether NRC has jurisdiction in the first place. To do so would enteil the conduct of an adjudicatory proceeding in order to see whether another adjudicatory licensing proceeding must be held. More importantly, the Commission considers that the existing record contains all the factual information needed for a decision and that no unresoived material factual issues remain that would require further proceedings.

\section{Orher Considerations}

While both NRC and DOE have focused their attention upon the meaning of the statutory ferm "highlevel waste" and its application to the malerials in storage at Hanford, other considerations might come into play in determining whether or nat DOE ectivities are subject to licensing. In particular, it should be recalled that NRC exercises licensing authority under section 202(4) only as to "facilitios suthorized for the express purpose of subsequent long-term storage of [DOE. generated! high-level waste." The content of individual waste tanks is by no means dispositive of the question whether the facilities for storege of the treated waste are subject to licensing. A number of other factors may be releven and material es well: (1) What ere the limits, goographically and functionally, of "facilities"; (2) have those facilities been "euthorized" (and by whom is such authorization required); and (3) have those facilities been authorized "for the exprese purpose of subsequent long-term storage of high-level weste" where those who may authorize the facility make no express mention of high-level waste? It is not necessery for the Commission to sddress these questions at length in order to dispose of the panding petition.

\section{Public Comments on the Petition}

The NRC received letters from 12 commenters. Two letters were from other Federal egencies, two were from public interest groups, one was from a nuclear industry corporation, and seven were from private individuals. Most comments were oppoeed to the petition.

\section{A. Process and Stundards Proposed in} Petition

Severel comments expressed concern thet granting the petition would heve an adverse effect on the timely disposal of redioactive weste at Hanford. This wes a concem because many of the Hanford waste tanks were seen as nearing or exceeding their design life. The provisions of the rulemaking proposed in the potition were viewed es limiting DOE's flexibility in selecting the most effective processes for weste treatment and disposal. The petitioner's request that "best available technology" be used in removing HLW material from the tank wastes wes seen as ignoring costs of disposel, exposures to workers, and environmental impacts.

Some comments disputed the petitioner's claim thet the rulemaking proposed in the petition would offer a better process for classification and disposel of the Hanford tank wastes. These commenters did not see any edvantage in the proposed process over the process for classification and disposel currently in use. One comment suggested that the Commission's rulemaking requiring disposel of Greater-than-Class (C) weste in a geologic repository or Commission-approved eltemative (53 FR 17710, May 19, 1989) might force DOE to allocate resources to handle the hazards, rather than to waste further time fruitlessly searching for ways to remove more and more activity from one part of the waste. The action proposed by the petitioners was viewed as not increasing the safoty of disposal of the waste.

The Commission believes that adherence to the standard of technical and economic practicality generally reflects agroement with these comments.

B. Creation of a Aisk-Based Classification System

Several comments, while noting that the rulemaking proposed by the petition would not do so, favorad creation of a risk-based system of redioactive waste classification.
The Commission has previously addressed the costs and benefits of cresting a new system of radioactive weste classification. Its rationale for not doing so is outlined in the statement of considerations to the proposed pert 61 rulemaking on disposal of Greater-than Class C waste (53 FR 17709, May 18, 1988). Further consideration of these issues is beyond the acope of this proposed rulemaking action.

\section{NRC Licensing Authority}

Some comments focused on the licensing authority of NRC over the Hanford tank wastes. DOE stated that the rulemaking suggested in the petition would involve NRC in regulation of DOE's predisposal waste treatment and processing activities, which would be inconsistent with NRC authority to license specific DOE faclities under the Energy Reorganization Act of 1974 . Another commenter stated that the proposed rulemaking was inconsistent with the statutory responsibilities of DOE and NRC. These arguments heve already been discussed, and require no further response. It may be emphesized, however, that even if the Commission were found to have jurisdiction over the disposal facilities, it would not regulate either the tanks themseives or the facilities being used to process the wastes in these tanks; and there is reason for concern that implementation of the petitioner's proposal might draw the Commission improperly into regulation of those facilities.

$A$ commenter concluded that DOE was currently in violation of $10 \mathrm{CFR}$ part 30 requirements for a license because various near-gurface waste disposal facilities at.Hanford are being used for "long-term storage" of highlevel redicective waste. The issue is not pertinent to the subject matter of the petition. However, in any case, the comment does not take into consideration the judicial interpretation of the term in Natural Resources Defense Council, Inc. v. U.S. Nucleor Regulatory Commission, 606 F.2d 1261 (D.C. Cir., 1879). The D.C. Circuit Court of Appeals ruled in this case in support of NRC's position that the tanks have not been authorized for use as long-term storage or disposal and are, therefore. not subject to NRC licenting.

\section{Public Input}

A number of comments streseed the importance of adequate public input into decision making regarding disposel of the Hanford tank wastes. Some called for public hearings on this subject to be held in the Pacific Northwest. One commenter noted that the EIS which was done for Hanford provided the 
opportunity for public comment. Another commenter believed that the Commission's rulemaking procedures did not offer the public a better opportunity for input than does the current licensing procedure.

As indicated in the Discussion above, the NRC's review of the situation with respect to the double-walled tanks has been carried out publicly from the start. Meetings with DOE have beon open, and at least one of the petitioners (the State of Washington) has been provided advance notice and an opportunity to attend. Documents have been placed in the Public Document Room and have been made available for public inspection. It appears to the

Commission that the essence of the issue concerns the appropriate standard for evaluating whether certain wastes should be regarded as high-laval weste or not. Sufficient factual information is available to carry out these evaluations. Also, the petition for rulemaking has afforded an opportunity for viows to be expressed with respect to the eppropriateness of the stendard.

A decision that NRC lacks licensing jurisdiction does not maen that opportunities for public input will be denied. As DOE undertakes its waste management activities, it will afford opportunities for public participation to the extent required by its own enabling statutes, regulations, and orders.

\section{E. Other Comments}

One commenter took exception to the petitioner's cleim that the radioactive inventory of the Hanford tank wastes was inadequately known. The commenter believed that the contents of the tanks can be bounded well enough to judge the relative sofety of various disposal options.

The Commission considers the evsilable information to be sufficiently bounded to onable it to conclude that DOE's proposed operations (with respect to the material stored in the double-shell tanks) can result in the removal from the Hanford double-shell tanks of as much of the radioactive waste 85 may be technically and oconomically practical, and that the applicable regulatory objectives have been satisfied. Once these judgments are made, it is not the NRC's role to judge the relative safety of various disposal options, and we decline to do so.

One comment stated that while the petition was aimed solely et the Hanford tank wastes, its provisions could potentially affect all radioective wastes from reprocessing, including those at Savannah River, West Valley, and the idaho National Engineering Laboratory. As the waste management programs at these other sites are in different stages of implementation, the impacts of the provisions would vary from site to site. As indicated above, the Commission is sensitive to this consideration yet believes that the specific case at hand only needs to be addressed at this time. Some comments unged the Commission not to change the present definition of HLW. The Commission is not chenging the present definition.

\section{Conclusion}

For the reasons presented in this document, the petition for rulemsking is denied.

Dated at Rockvillo. Msryland this 26th dey of Februsry. 1983.

For the Nuclear Regulatory Commission. Samuel J. Chill.

Secretory of tha Commission.

[FR Doc. 93-4944 Filed 3-3-93; 8:45 am]

Numo cooe nem-91-P

\section{DEPARTMENT OF TRANSPORTATION}

Fedoral Aviation Adminlstration

\section{CFA Part 39}

[Docket No. 03-Nin-O5-AD]

Airworthinese Directives; Boeing Model 737 Sarles Airplanes

AGEnCY: Foderal Avietion Administration, DOT.

actnow: Notice of proposed rulemaking (NPRM).

summary: This document proposes the superaedure of an existing airworthiness directive (AD), applicable to certain Boeing Model 737 series airplanes, that currently requires repetitive inspections of the wing main tank floet switch electrical conduits for trepped water, and removal of the water, if found. This action would require installation of grease in the interior of the floet switch conduits, which would terminate the requirement for repretitive inspections of the conduits. This action would also expand the applicability of the rule. This proposal is prompted by the development of a modification that would preclude the possibility for water to accumulate in the conduits. The ections specified by the proposed AD are intended to prevent fuel leakage from the wing main tanks, which could propegate down the wing leading edge cavity, on to the respective engine tail pipe, and cause an axternal fire under the wing.

DATES: Comments must be received by April 27, 1993.

ADDFESSE8: Submit comments in triplicate to the Federal Aviation
Administration (FAA), Transport Airplane Directorete, ANM-103, Attention: Rules Docket No, 93-NM05-AD, 1601 Lind Avenue, SW., Renton, Washington 98055-4056. Comments may be inspected at this location between 9 a.m. and 3 p.m. Monday through Friday, except Federa! holidays.

The service information referenced in the proposed rule mey be obtained trom Boeing Commercial Airplane Group. P.O. Box 3707, Seattle, Washington 98124-2207. This information may be exemined at the FAA. Trensport Airplane Directorate, 1601 Lind Avenue, SW., Renton. Washington. FOA FUATHER WFORUATON CONTACT: Stephen Bray, Aerospace Engineor, Seattle Aircraft Certification Office, Propulsion Branch, ANM-140S, FAA, Transport Airplane Di inectorate, 1601 Lind Avenue, SW., Renton, Washington 98055-4056; telephone (206) 227-2681; fax (206) 227-1181.

\section{SUPPLEMENTAAY WFORMATION:}

\section{Comments Inviled}

Interested persons are invited to participate in the making of the proposed rule by submitting such written data, viows, or ar c thents as they may desire. Communicetions shall identify the Rules Docket number and be submitted in triplicate to the addrass specified above. All communications received on or bafore the closing date for commente, epecified above, will be considered before taking action on the proposed rule. The proposels contained in this notice may be changed in light of the comments received.

Comments are specificslly invited on the overall regulatory, economic. environmental, and energy aspects of the proposed rule. All comments submitted will be avallable, both before and ofter the closing date for comments in the Rules Docket for examination by interested persons. A report summarizing each FAA-public contact concerned with the substance of this proposel will be filed in the Rules Docket.

Commenters wishing the FAA to acknowledge receipt of their comments submitted in respones to this notice must submit a self-addreseed, stamped postcard on which the following statement ís made: "Comments to Docket Number 83-NM-05-AD." The postcard will be date stamped and returned to the commenter.

\section{Aveilability of NPRM.}

Any person may obtain a copy of this NPRM by submiting a request to the FAA, Transpor Airplane Direciorate. 
APPENDIX B

\section{COST ESTIMATES}


WHC-SD-WM-TI-699, Rev. 1

This page intentionally left blank. 


\section{APPENDIX B}

\section{COST ESTIMATES}

The study used costs taken from existing sources to the extent possible. These sources include prior engineering studies, conceptual designs, and data packages supporting the TWRS Environmental Impact Statement (in preparation). This appendix provides a reference to the sources used for cost estimation. In addition, the study includes allowances for technologies not completely evaluated by previous engineering studies. Some economic assessments are presented for technologies determined not to be technically practical and are provided for information only.

For the technologies with developed cost estimates, the cost presented represent a Total Estimated Cost (TEC) without escalation applied. The estimates have engineering factors applied depending on the types of facility ranging from 20 to 40 percent and a contingency of 30 to 40 percent.

For the technologies costed by allowance, the allowances have a great deal of conservatism built into them. The cost to deploy these technologies should be lower than the cost used in this study. These technologies' costs come from similar or more complex systems.

\section{B1.0 BASELINE PRETREATMENT PROCESS}

This baseline pretreatment processing differs from the current TWRS baseline process by the absence of cesium removal using ion exchange. Cesium removal by ion exchange is addressed as a radionuclide removal technology option in Section 4.2.2. The baseline pretreatment processes, along with cesium ion exchange, were adopted as the basis for the Tri-Party Agreement (Ecology et al. 1994).

The baseline processing results in an estimated total capital, operating, and geologic disposal cost savings of $\$ 9$ billion over geologic disposal of all tank wastes (no separation of a LAW fraction). The cost savings is determined by difference of the capital, operating, and geologic disposal costs defined in technical data packages for the TWRS Environmental Impact Statement (EIS) for no separations (Colby 1995) and the Tri-Party Agreement alternatives (Slaathaug 1995). The Tri-Party Agreement alternative data package costs are adjusted for this comparison by subtracting the cesium ion exchange portion of the costs to obtain the costs associated with solids/liquids separations (which includes enhanced sludge washing). 


\section{B1.1 CESIUM REMOVAL COSTS}

This section reviews the cost basis for the cases carried in the document to remove cesium from the tank waste supernatant. The technologies costed include cesium volatility, singlecycle cesium ion exchange, second-cycle cesium ion exchange, CST in facility, selective CST in tank, and selective in facility single-cycle cesium ion exchange.

\section{B1.2 CESIUM VOLATILIZATION}

An allowance of $\$ 30$ million for capital and $\$ 20$ million for operations is used for cesium volatilization (Section 3.2.3). The base line facilities contain much of the equipment to support cesium recycle to the melter. To remove the volatilized cesium, it is necessary to modify the equipment design and configuration. The modification include separations equipment for volatile species.

An estimate is not specifically available for this equipment. However, a far more complex modification of the melter offgas system was estimated by Fluor Daniel, Inc. (Chloride Removal from Vitrification Offgas, WHC-SD-WM-TI-702, Rev. 0, May 23, 1995, E. J. Slaathaug, pages 19-20) for WHC to estimate chloride removal systems. Table B-1 shows the results of that study.

Table B-1. Chloride and Fluoride Removal System Costs.

\begin{tabular}{|l|c|}
\hline & Cost \\
\hline Chloride and fluoride purge distillation and grouting equipment & (S millons? \\
\hline Facility differential & 48.4 \\
\hline Annual operating & 8.7 \\
\hline
\end{tabular}

The chloride and fluoride estimate specified Hastelloy and Inconel materials in the equipment to withstand the corrosion which cost more than stainless steel necessary for the cesium removal system.

What can be learned from this comparison is that cesium recovery equipment is required to recycle cesium back to the melter under any scenario. The delta above the recycle capability to route the cesium to HLW storage is conservatively bracketed by the above chloride estimates at $\$ 30$ million capital and $\$ 20$ million operating. A preliminary material balance shows no need for the addition of extensive unit operations to support this option. 


\section{B1.3 SINGLE-CYCLE ION EXCHANGE}

The cost for cesium removal by ion exchange is based on data in the TWRS EIS data package (Slaathaug 1995, Table F-36). The capital cost for cesium ion exchanges is $\$ 380$ million. The total operational cost for the cesium ion exchange system including research and development, start-up, operation, and Decontamination and Decommissioning (D\&D) costs is $\$ 602$ million.

This design used a transfer aisle facility design as the basis for cost. The development of these costs come from detail material and energy balances, staffing estimates, equipment lists, and facility layouts. The basis for this estimate has evolved over a five-year period.

Table B-2. Cost from Slaathaug 1995, Table F-36.

\begin{tabular}{|l|c|}
\hline & Corilions \\
\hline Research and development & 83 \\
\hline Capital (e.g., construction) & 380 \\
\hline $\begin{array}{l}\text { Labor for start-up, operations, and decontamination and } \\
\text { decommissioning }\end{array}$ & 276 \\
\hline Equipment Replacement & 57 \\
\hline $\begin{array}{l}\text { Materials for start-up, operations, decontamination and } \\
\text { decommissioning }\end{array}$ & 186 \\
\hline Total & 982 \\
\hline
\end{tabular}

\section{B1.4 SECOND-CYCLE ION EXCHANGE}

The costs associated with a second cycle of cesium ion exchange are derived from the difference in costs for separations facilities containing two cycles and one cycle of cesium ion exchange developed in the TWRS Facility Configuration Study (Boomer et al. 1994). The second cycle of cesium ion exchange increased the capital estimate by $\$ 275$ million (Table 6.3-1, Boomer et al. 1994). The facilities' cost come from a low maintenance facility design. This facility design has a lower estimate than the facility design used for the singlecycle cesium ion exchange. If the transfer aisle design was used, this delta would increase.

The operating cost difference for the second cycle of cesium ion exchange is $\$ 47$ million (Table 4.1-4, Boomer et al. 1993). The second-cycle cesium ion exchange has increased equipment replacement cost of $\$ 15$ million and increased D\&D cost of $\$ 83$ million based on the capital cost delta of $\$ 275$ million. The other costs associated with cesium ion exchange were estimated not to change between the single-cycle and double-cycle ion exchange. 
Table B-3. Cost Differences from Boomer et al. 1994.

\begin{tabular}{|c|c|c|c|}
\hline 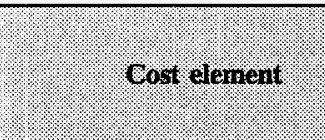 & $\begin{array}{l}\text { Single cyele: } \\
\text { cerrum ion } \\
\text { exchange cost } \\
(S \text { millions }\end{array}$ & 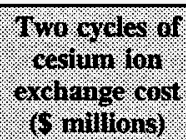 & $\begin{array}{l}\text { Coat } \\
\text { differences } \\
\text { (s milions) }\end{array}$ \\
\hline Capital (e.g., construction) & 426 & 701 & 275 \\
\hline Materials for operations & 96 & 143 & 47 \\
\hline Equipment Replacement & 45 & 60 & 15 \\
\hline $\begin{array}{l}\text { Decontamination and } \\
\text { decommissioning }\end{array}$ & 194 & 277 & 83 \\
\hline Total & 761 & 1,181 & 420 \\
\hline
\end{tabular}

\section{B1.5 CESIUM SORPTION BY CST TREATMENT OF ALL WASTES}

Costs for use of CST in columns for all the tank waste is analogous to single-cycle ion exchange in columns described above. Since CST is not regenerated, the facility costs are lowered because regeneration equipment and floor space are not required. The reduced facility size decreases the labor cost for operation, but the material cost for CST more than off sets this and reduction and raises the operational cost for this alternative above singlecycle cesium ion exchange. Also the use of CST increases the volume of HLW. This increase has an estimated value of $\$ 745,000$ per canister.

A detailed cost estimate was not developed for CST columns and allowances have been developed. Table B-4 shows the cost for a CST facility compared to the single-cycle ion exchange facility. The total operating cost for pretreatment and the HLW treatment delta is $\$ 1,860$ million ( $\$ 1,670$ million in HLW costs and $\$ 198$ million operating) for CST treatment of all waste to remove cesium. The capital and operating total is $\$ 1,688$ million. 
Table B-4. High-Level Waste Cost from Slaathaug 1995, Table F-36.

\begin{tabular}{|c|c|c|c|}
\hline (i: & $\begin{array}{l}\text { Single cycle ion } \\
\text { exchange cost from the } \\
\text { His enta pacict }\end{array}$ & $\begin{array}{l}\text { Crvitalline } \\
\text { silicatitanate cost } \\
\text { allowinge }\end{array}$ & $\begin{array}{l}\text { Cost } \\
\text { difference } \\
\text { (\$ millions) }\end{array}$ \\
\hline Capital (e.g., construction) & 380 & 200 & $(180)$ \\
\hline Operational cost & 602 & 800 & 198 \\
\hline $\begin{array}{l}\text { High level waste delta cost } \\
\text { for an incremental } 2,240 \\
\text { canisters }\end{array}$ & 0 & 1,670 & 1,670 \\
\hline Total & 982 & 2,670 & 1,688 \\
\hline
\end{tabular}

The cost used for calculating the incremental cost per HLW canister come from the EIS data packet for the Tri-Party Agreement Alternative (Slaathaug 1995, Table F-36). The HLW cost from the data packet consist of fixed and variable cost. Table B-5 shows the split between the cost types. The fixed cost consisted of research and development costs and capital cost both of which do not factor into the cost of producing an extra canister of glass. The repository cost increases by the amount of $\$ 745$ thousand per incremental HLW canister as shown below (Slaathaug 1995, Table F-36), based on a variable cost of $\$ 5.065$ billion for 6,800 canisters.

Table B-5. High-Level Waste Cost from Slaathaug 1995, Table F-36.

\begin{tabular}{|l|c|c|}
\hline \multicolumn{1}{|c|}{ Cost element } & Tued cost (\$) & Yariable eost \\
\hline Research and development & 260 & \\
\hline Capital (e.g., construction) & 1,400 & \\
\hline $\begin{array}{l}\text { Labor for start-up, operations, and } \\
\text { decontamination and decommissioning }\end{array}$ & & 639 \\
\hline Equipment Replacement & & 70 \\
\hline $\begin{array}{l}\text { Materials for start-up, operations, } \\
\text { decontamination and decommissioning }\end{array}$ & & 604 \\
\hline High level waste canisters & & 239 \\
\hline Transportation & & 31 \\
\hline Repository fee & & 3,960 \\
\hline Total & 1,600 & 5,065 \\
\hline
\end{tabular}




\section{B1.6 CST TREATMENT OF SELECTED TANKS}

Prior estimates do not provide a direct basis for CST addition to double-shell tanks. The process of adding the CST slurry to a double-shell tank and obtaining the required contact efficiency is simplified by in tank washing and retrieval operations necessary for other reasons. CST addition for selected tanks is held below the level at which titanium impacts the HLW glass loading. The remaining costs include the capital to add CST to the tanks as a slurry and a small operating delta to accommodate the mixing via operation of existing mixer pumps.

The operating cost per incremental HLW canister is approximately $\$ 745,000$ (Slaathaug 1995, Table F-36). This includes labor, materials, and geologic disposal. The geologic disposal costs are assumed to be $\$ 582,000$ per canister assuming two repositories (Slaathaug 1995). An allowance of $\$ 2$ million per tank of treated waste is assumed for pretreatment operating costs including development, chemical purchases, and incremental tank farm operations to perform the batch contacts and decants.

An allowance of $\$ 5$ million is provided for capital cost requirements associated with addition of CST slurries to the wastes before or during the retrieval step. It is assumed that the retrieval operation will provide adequate contact with the CST solids before the following settle/decant operation. The operating costs associated with addition of the CST slurries are $\$ 25$ million for operating labor and CST purchase costs. The selective treatment of wastes with CST assumes two CST costs to bound the analysis. The currently quoted price for small quantities is $\$ 176 / \mathrm{kg}$ of CST powder. An alternate price for CST costs with the large amounts envisioned by this process was assumed to be equal to $\$ 1 / \mathrm{Ci}$ of ${ }^{137} \mathrm{Cs}$ removed. This assumed large volume price break results in a assumed unit price reduction of 40 to 85 percent.

\section{B1.7 PHASED PROCESSING AND MODULAR FACILITIES}

During development of the study the use of selective CST showed a favorable cost as compared to global application of cesium ion exchange. As such, the study revisited the single-cycle cesium ion exchange data to find an analogous application. Table B-6 summarizes three facility cases for application of cesium ion exchange. The cases and specific sources of capital and operating costs are as follows:

1. Full Treatment (treatment of all tanks in a full size facility) is taken from the EIS data package. WHC-SD-WM-EV-104, Rev.0-A TPA Alternative Engineering Data Package for the TWRS EIS E. J. Slaathaug, July 1993, Table F-36. 
2. The modular treatment concept for a 15 GPM capacity was developed by BNFL as a facility configuration study (FCS) alternative for cesium removal. The costs in the table are for treatment of 12 DST's containing the majority of the cesium (NCAW, CC, DSS/DSSF). WHC-SD-WM-ES-295 Rev. 0, TWRS Facility Configuration Study, K. D. Boomer, July 13, 1994, Table 6.2-1.

3. Modular treatment at 5 GPM supporting the privatization RFP was developed at the request from DOE and documented in two letters; the first for capital costs and the second for operating costs. Letter 9551934, May 1, 1995, Privatization Cost Estimate (Business Sensitive), J. S. Garfield to D. L. Veith, Letter 9552911, May 26, 1995, "Estimate of Privatization Operation Cost" J. S. Garfield to L. S. Waldorf.

The costs in the table are for treatment of 12 DST's containing the majority of the cesium (NCAW, CC, DSS/DSSF).

Table B-6 Global and Selective Cesium Ion Exchange Costs.

\begin{tabular}{|c|c|c|c|}
\hline 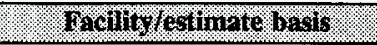 & Wall & Woular & Modular \\
\hline Throughput (GPM) & $25 @ 7 M$ & $15 @ 5 M$ & $5 @ 5 M$ \\
\hline Yrs to Process 12 DSTs & 2 & 5 & 14 \\
\hline \multicolumn{4}{|l|}{ Costs (\$ millions): } \\
\hline $\begin{array}{l}\text { Capital Construction } \\
\text { - Maintenance } \\
\text { - Analytical } \\
\text { Operating Labor (LCC) } \\
\text { Replacement Equipment (LCC) }\end{array}$ & $\begin{array}{c}38 \\
-- \\
-- \\
276 \\
57\end{array}$ & $\begin{array}{r}170 \\
20 \\
20 \\
100 \\
15\end{array}$ & $\begin{array}{r}100 \\
20 \\
20 \\
276 \\
50\end{array}$ \\
\hline $\begin{array}{l}\text { Materials \& Supplies } \\
\text { - Startup } \\
\text { - D\&D } \\
\text { - Chemicals \& Consumables }\end{array}$ & $\begin{array}{r}21 \\
109 \\
56\end{array}$ & $\begin{array}{l}20 \\
60 \\
10\end{array}$ & $\begin{array}{l}10 \\
40 \\
10\end{array}$ \\
\hline $\mathrm{R} \& \mathrm{D}$ & 83 & 83 & 83 \\
\hline $\begin{array}{l}\text { Total } \\
\text { (Totals Used) }\end{array}$ & $\begin{array}{c}982 \\
(1,000)\end{array}$ & $\begin{array}{c}493 \\
(500)\end{array}$ & $\begin{array}{c}609 \\
(600)\end{array}$ \\
\hline
\end{tabular}

${ }^{1}$ Slaathaug, E. J., 1993, TPA Alternative Engineering Data Package for the TWRS EIS, WHC-SD-WM-EV-104, Rev. 0-A, Westinghouse Hanford Company, Richland, Washington.

${ }^{2}$ Boomer, K. D., et al. 1994, TWRS Facility Configuration Study, WHC-SD-WM-ES-295, Rev. 0, Westinghouse Hanford Company, Richland, Washington.

${ }^{3}$ Garfield, J. S., 1995, Privatization Cost Estimate (Business Sensitive), letter 9551934 to D. L. Veith; and Garfield, J. S., 1995, Estimate of Privatization Operation Cost, letter 9552911 to L. S. Waldorf. 


\section{B2.0 STRONTIUM REMOVAL}

This section reviews the cost basis for the cases carried in the document to remove strontium from the tank waste supernatant. The technologies costed include solvent extraction, strontium removal by precipitation as phosphate, selective complexant deactivation, and complexant destruction.

\section{B2.1 STRONTIUM REMOVAL BY SOLVENT EXTRACTION}

The cost for strontium removal by solvent extraction is based on facility designs presented in the Tank Waste Technical Options Report (Boomer et al. 1993). The cost of a solvent extraction system collocated with another processing facility is based on the cost differences between two pretreatment facilities with and without the solvent extraction system. These two facilities are identified as Sludge Wash B (SWB) and Solvent Extraction B (SOLEX B), with and without the solvent extraction, respectively, in the reference report (Boomer et al. 1993). The capital costs for these two facilities are updated for this report. Summary of the updated SWB is found in Appendix C. The difference in costs between SWB and SOLEX B provides a basis for the cost difference of a LAW vitrification facility with and without solvent extraction capability. Solvent extraction is used for strontium recovery with transuranic extraction (TRUEX) processes. The difference in capital costs associated with solvent extraction is $\$ 1.22$ billion. The difference in operating costs associated with operation of the solvent extraction system is identified by the difference in operating costs for the SWB and SOLEX B facilities of $\$ 6.69$ billion (Boomer et al. 1993).

The in-facility process for strontium removal by solvent extraction treatment of ALL wastes is expected to remove $3.4 \mathrm{MCi}$ of the $3.5 \mathrm{MCi}$ soluble and insoluble strontium from the liquid fraction. The removal of $3.4 \mathrm{MCi}$ of ${ }^{90} \mathrm{Sr}$ for a total cost of $\$ 7.9$ billion results in a removal cost of $\$ 2,320 / \mathrm{Ci}$.

\section{B2.2 PRECIPITATION OF STRONTIUM PHOSPHATE}

Addition of strontium nitrate to the three CC waste tanks would impact the HLW glass volumes with an increase of $75 \mathrm{HLW}$ canisters at a unit delta of $\$ 745,000$ each as explained in Section B1-3. The allowance for capital costs can conservatively be zero.

Capital:

Operating: 75 HLW Canisters @ 745,000 each
$=-0$

$=\$ 56$ million 


\section{B2.3 STRONTIUM REMOVAL BY COMPLEXANT DEACTIVATION IN SELECTED WASTES}

Complexant deactivation is accomplished by in-tank heat and digest for the three CC waste tanks affected. The capital and operating cost impacts are $\$ 150$ million and $\$ 50$ million respectively. The numbers are developed in the following reference.

Klem, M. J., Preliminary Engineering Evaluation of Heat and Digests Treatment for In-Tank Removal of Radionuclides From Complexed Hanford Tank Waste, WHC-SD-SM-TI-719, Rev. 0, Table 2-3.

\section{B2.4 STRONTIUM REMOVAL BY COMPLEXANT DESTRUCTION IN ALL WASTES}

The cost for strontium removal by complexant destruction is based on facility designs presented in the Tank Waste Technical Options Report (Boomer et al. 1993). The cost of a complexant destruction system collocated with another processing facility is based on the cost differences between two pretreatment facilities with and without the complexant destruction system. These two facilities are identified as Sludge Wash C (SWC) and Sludge Wash B (SWB), with and without the complexant destruction, respectively, in the reference report (Boomer et al. 1993).

The capital costs for these two facilities are updated for this report. Summaries of the updated SWC and SWB cost estimates are found in Section B7.0 The difference in costs between SWC and SWB provides a basis for the cost difference of a LAW vitrification facility with and without complexant destruction capability. The difference in capital costs associated with strontium removal by complexant destruction is $\$ 381$ million. The difference in operating costs associated with operation of the complexant destruction system is identified by the difference in operating costs for the SWC and SWD facilities of $\$ 330$ million for training, operations, essential materials, and decontamination and decommissioning (Boomer et al. 1993, Table G16-15). Table B-7 shows the costs for organic destruction.

Table B-7. Costs for Organic Destruction.

\begin{tabular}{|c|c|c|c|}
\hline Cost etimate & $\begin{array}{l}\text { Capitai cost } \\
\text { (S millions) }\end{array}$ & $\begin{array}{l}\text { Other cost } \\
\text { (6 nillions) }\end{array}$ & . Trual cast \\
\hline Sludge Wash C & 1,913 & 2,670 & 4,583 \\
\hline Sludge Wash B & 1,532 & 2,340 & 3,872 \\
\hline Delta & 381 & 330 & 711 \\
\hline
\end{tabular}




\section{B3.0 TRANSURANIC REMOVAL}

This section reviews the cost basis for the cases carried in the document to remove TRU from the tank waste supernatant.

\section{B3.1 HYDROXIDE PRECIPITATION OF TRU FROM SELECTED WASTES}

This option entails addition of $19 \mathrm{M} \mathrm{NaOH}$ and $.01 \mathrm{M}$ ferric ion to the three $\mathrm{CC}$ waste tanks to achieve a $3 \mathrm{M}$ hydroxide concentration to precipitate the TRU. The allowance for capital impacts from adding chemicals to the $\mathrm{CC}$ waste tanks is considered negligible. Features to add chemicals are presently available and mixing is accomplished by the mixer pumps required for retrieval.

The total operating costs for adjustment of the hydroxide concentration and addition of $0.01 M$ iron in the DSTs several weeks or months before retrieval and solids/liquid separation is $\$ 6$ million to $\$ 18$ million as summarized in Table $\mathbf{B}-8$ :

Table B-8. Hydroxide Precipitation Costs.

\begin{tabular}{|c|c|}
\hline Grist cloment & (sost. \\
\hline Sodium hydroxide & 0.6 \\
\hline $\begin{array}{l}\text { Additional low-activity waste vaults } \\
\text { (for } 0.14 \text { Vaults) }\end{array}$ & 1.4 \\
\hline $\begin{array}{l}\text { Iron impact on high-level waste } \\
\text { (additional } 5 \text { to } 21 \text { canisters) }\end{array}$ & 3.7 to 16 \\
\hline Total operating & 6 to 18 \\
\hline
\end{tabular}

A LAW cost increase of $\$ 2$ million is based on addition of $19 M \mathrm{NaOH}$ to the three tanks to a $3 M \mathrm{NaOH}$ final concentration which increases the total tank waste sodium by $250 \mathrm{MT}$ or 0.14 equivalent vaults. The disposal cost per vault of solidified LAW is approximately $\$ 10$ million (Slaathaug 1995, Table F-36). This includes containers, sulfur matrix, and vault costs. The incremental Na usage results in $\$ 1.4$ million increase in LAW disposal costs. The addition of $\mathrm{NaOH}$ to the tanks is estimated to cost $\$ 0.6$ million.

The addition of the $0.01 M$ iron results in an additional 5 to 21 canisters of HLW glass. The canisters are assumed to contain $1.26 \mathrm{~m}^{3}$ of glass and a maximum $\mathrm{Fe}_{2} \mathrm{O}_{3}$ content of 12 wt\% (Orme 1994). The minimum HLW canister impact is based on 50 wt $\% \mathrm{Fe}_{2} \mathrm{O}_{3}$ if the $\mathrm{HLW}$ facility is processing glass at less than the $12 \mathrm{wt} \% \mathrm{Fe}_{2} \mathrm{O}_{3}$ limit and the maximum $\mathrm{HLW}$ canister impact is based on the $12 \mathrm{wt} \% \mathrm{Fe}_{2} \mathrm{O}_{3}$ limit. With an incremental HLW canister cost 
of $\$ 745,000$ per HLW canister (Slaathaug 1995), this results in an additional operating cost of approximately $\$ 3.7$ to $\$ 16$ million.

\section{B3.2 TRANSURANIC REMOVAL FROM SELECTED WASTES BY FERRIC HYDROXIDE PRECIPITATION}

The addition of $0.1 M \mathrm{Fe}\left(\mathrm{NO}_{3}\right)_{3}$ and $3.0 \mathrm{M} \mathrm{NaOH}$ for precipitation of TRU to the three $\mathrm{CC}$ tanks results in a maximum additional 50 to 21.0 canisters of HLW glass. The canisters are assumed to contain $1.26 \mathrm{~m}^{3}$ of glass and a maximum $\mathrm{Fe}_{2} \mathrm{O}_{3}$ content of $12 \mathrm{wt} \%$ (Orme 1994). The minimum HLW canister impact is based on $50 \mathrm{wt} \% \mathrm{Fe}_{2} \mathrm{O}_{3}$ if the $\mathrm{HLW}$ facility is processing glass at less than the $12 \mathrm{wt} \% \mathrm{Fe}_{2} \mathrm{O}_{3}$ limit and the maximum $\mathrm{HLW}$ canister impact is based on the $12 \mathrm{wt} \% \mathrm{Fe}_{2} \mathrm{O}_{3}$ limit. With an incremental $\mathrm{HLW}$ canister cost of $\$ 745,000$ per HLW canister (Slaathaug 1995), this results in an additional operating cost of approximately $\$ 37$ to 160 million. The incremental LAW costs are $\$ 2$ million as developed in Section C3-1. Totals are summarized as follows:

$\mathrm{NaOH}$ chemical Costs

LAW Vault incremental cost (0.14 Vaults)

Iron impact on HLW (50-210 Canisters)

Total operating Cost
$\$ 0.6$ million

$\$ 1.4$ million

$\$ 37-160$ million

\$39-162 million

\section{B3.3 TRANSURANIC REMOVAL BY COMPLEXANT DEACTIVATION IN SELECTED WASTES}

Complexant destruction is accomplished with in tank heat and digest for the three $\mathrm{CC}$ waste tanks affected. The capital and operating cost impacts are $\$ 150$ million and $\$ 50$ million respectively. The numbers are substantiated in the following reference.

Klem, M. J., Preliminary Engineering Evaluation of Heat and Digests Treatment for In-Tank Removal of Radionuclides From Complexed Hanford Tank Waste, WHC-SD-SM-TI-719, Rev. 0, Table 2-3.

\section{B3.4 TRANSURANIC REMOVAL BY COMPLEXANT DESTRUCTION IN ALL WASTES}

The explanation for the cost basis for this option is identical to complexant destruction for strontium removal discussed in Section B2.3.

\section{B3.5 TRANSURANIC REMOVAL BY SOLVENT EXTRACTION}

The explanation of the cost basis for this option is identical to strontium solvent extraction discussed in Section B2.1. 


\section{B4.0 TECHNETIUM-99 REMOVAL}

This section reviews the cost basis for the cases carried in the document to remove technetium from the tank waste supernatant. The technologies include technetium volatilization, mixed bed technetium ion exchange, and technetium anion exchange.

\section{B4.1 TECHNETIUM VOLATILIZATION}

The explanation for the cost basis for this option is identical to cesium volatilization discussed in Section B1.1.

\section{B4.2 MIXED BED TECHNETIUM AND CESIUM ION EXCHANGE}

The mixed bed ion exchange removal system is assumed to remove 99 percent of the soluble ${ }^{99} \mathrm{Tc}$, or $0.0216 \mathrm{MCi}$ of the $0.0228 \mathrm{MCi}$ soluble ${ }^{99} \mathrm{Tc}$. No breakthrough data are available to perform specific equipment sizing or material balance calculations. The potential costs of the mixed bed system assume that the bed volume of the combined resins and the elution volumes are increased 25 percent. It is assumed that the capital and operating costs are increased 10 and 20 percent, respectively, over the costs of a cesium only ion exchange system \{see Section C1.2 (Slaathaug 1995, Table F-36)\}. The capital and operating costs of the cesium only ion exchange system are $\$ 380$ and $\$ 602$ million, respectively. The incremental capital and operating cost increase for the mixed bed technetium recovery are $\$ 38$ and $\$ 120$ million, respectively. The total incremental cost of 158 million results in a cost of $\$ 7,200 / \mathrm{Ci}$ of removed ${ }^{99} \mathrm{Tc}$.

\section{B4.3 TECHNETIUM ANION EXCHANGE}

The cost for technetium removal by ion excharge is based on facility and equipments designs presented in the Tank Waste Technical Options Report (Boomer et al. 1993). The cost of a technetium ion exchange system collocated with another processing facility is based on the cost differences between two pretreatment facilities with and without the technetium ion exchange process. These two facilities are identified as Sludge Wash D (SWD) and Sludge Wash B (SWB), with and without the technetium ion exchange, respectively, in the reference report (Boomer et al. 1993).

Both facilities include sludge washing, solids/liquids separation, and cesium ion exchange. The capital costs for these two facilities are updated for this report. Summaries of the updated SWD and SWB cost estimates are found in Section C7.0. The difference in costs between SWD and SWB provides a basis for the cost difference of a LAW treatment or vitrification facility with and without technetium ion exchange capability. The difference in capital costs associated with technetium ion exchange processing is $\$ 260$ million. The difference in operating costs associated with operation of the technetium ion exchange processing is identified by the difference in operating costs for the SWD and SWB facilities 
of $\$ 400$ million for training, operations, essential materials, and decontamination and decommissioning (Boomer et al. 1993, Table G16-15). Table B-9 provides the cost for technetium anion exchange.

The technetium ion exchange process recovers $0.0226 \mathrm{MCi}$ of ${ }^{99} \mathrm{Tc}$ for a total cost of $\$ 660$ million. This results in a cost of $\$ 29,000 / \mathrm{Ci}{ }^{99} \mathrm{Tc}$.

Table B-9. Costs for Technetium Anion Exchange.

\begin{tabular}{|c|c|c|c|}
\hline Sost estingater & (6) millings) & $(8,6,100)$ & hoorost \\
\hline Sludge Wash C & 1,532 & 2,340 & 3,872 \\
\hline Sludge Wash B & 1,272 & 1,940 & 3,212 \\
\hline Delta & 260 & 400 & 660 \\
\hline
\end{tabular}

\section{B5.0 SELENIIM REMOVAL}

Selenium removal is accomplished by volatilization in the LAW melter. The cost is identical to cesium removal discussed in Section B1.1. Selenium removal has no incremental cost above cesium and technetium. Selenium volatilization is not technically practical. The economics provided below are for information only.

The melter volatility system is assumed to remove 80 percent of the feed Se (DF of 5 ). The melter volatility system thus removes $0.00082 \mathrm{MCi}$ of the $0.00103 \mathrm{MCi}{ }^{79} \mathrm{Se}$. Some volatilization also occurs for ${ }^{137} \mathrm{Cs}$ and ${ }^{99} \mathrm{Tc}$. For ${ }^{137} \mathrm{Cs}$, it assumed 50 percent of the feed cesium volatilizes $(0.5 \mathrm{MCi})$ and for ${ }^{99} \mathrm{Tc}, 0.0205 \mathrm{MCi}$ of the $0.0228 \mathrm{MCi}$ soluble ${ }^{99} \mathrm{Tc}$ volatilizes. The melter and offgas system that provides radionuclide removal costs approximately $\$ 50$ million. This results in a cost of $\$ 1.00$ per $\mathbf{C i}$. 


\section{B6.0 CARBON-14 REMOVAL}

The chemistry of carbon results in ${ }^{14} \mathrm{C}$ being distributed in supernatants and solids of all tanks. The organic carbon and carbonate content of the wastes will be converted to carbon dioxide, $\mathrm{CO}_{2}$, as a result of the LAW vitrification process. In the vitrification process a total of $6,500,000 \mathrm{~kg}$ of $\mathrm{CO}_{2}$ will be released in the offgas. The $6,500,000 \mathrm{~kg}$ of $\mathrm{CO}_{2}$ can be absorbed in slaked lime as $15,000,000 \mathrm{~kg}$ of $\mathrm{CaCO}_{3}$.

The recovery, packaging and geologic disposal of $15,000 \mathrm{Mg}$ of $\mathrm{CaCO}_{3}$ in approximately $6,0001.26-\mathrm{m}^{3}$ canisters would cost approximately $\$ 5$ billion. A cost of $\$ 5$ billion to mitigate the environmental release of $0.0053 \mathrm{MCi}^{14} \mathrm{C}$ results in a cost of $\$ 1,000,000 / \mathrm{Ci}$ and is not economically practical.

\section{B7.0 URANIUM REMOVAL}

This option is bounded by the Solvent Extraction B option discussed in the Tank Waste Technical Options Report (Boomer et al. 1993, Tables G16-14 and G16-15). These costs are summarized below.

$\begin{array}{ll}\text { Capital: } & \$ 2,490 \text { million } \\ \text { Operating: } & \$ 8,630 \text { million. }\end{array}$

\section{B8.0 COST TABLES FOR SLUDGE WASH FACILITIES}

The following tables provide cost estimates for the Sludge Wash B (SWB), Sludge Wash C (SWC), and Sludge Wash D (SWD) facilities defined in the Tank Waste Technical Options Report, WHC-EP-0616 (Boomer et al. 1993). The cost estimates in the reference were updated for this document to assure a consistent basis for the incremental costs of single process technology options. The cost estimates have been escalated to 1995 dollars. 
APPENDIX C

SOURCE OF TANK WASTE AT THE HANFORD SITE

C-1 
This page intentionally left blank. 


\section{APPENDIX C \\ SOURCE OF TANK WASTE AT THE HANFORD SITE}

The Manhattan Project established the Hanford Site in 1943 to produce plutonium for nuclear weapons in support of World War II. Plutonium production continued until January 1987 when the last production reactor ceased operation at the Hanford Site. Eight production reactors, one dual-purpose reactor ( $\mathrm{N}$ Reactor), and five reprocessing facilities operated at the Hanford Site to support that mission. These operations created a large quantity of radioactive wastes, much of which continues to be stored in 149 SSTs and 28 DSTs.

Figure $\mathrm{C}-1$ shows the cesium, strontium, technetium, and transuranic curie balance for the Hanford Site facilities, decayed to December 31, 1999. The figure depicts the route of cesium and strontium bearing waste into and out of the tank complex.

The radionuclide inventory of $178 \mathrm{MCi}$ (December 31, 1999, decay date) for waste entering the tanks shown in Figure $\mathrm{C}-1$ is the sum of inventories in the tanks and known removals from the tanks described in Sections C-2 and C-3.

\section{C1.0 WASTE ENTIERING THE TANKS}

The waste entering the tank came primarily from the reprocessing of spent nuclear fuel. The following sections provide a description of the wastes and other wastes discharged to the tanks.

\section{C1.1 FUEL REPROCESSING WASTE}

The Hanford Site used three different fuel reprocessing processes on irradiated fuel discharged from the reactors: Bismuth Phosphate (BiPO4), REDOX, and PUREX processes. This section provides a brief description of the processes and resulting reprocessing wastes discharged to the tanks.

\section{C1.1.1 Bismuth Phosphate Waste}

T Plant and B Plant discharged waste to the tanks from the $\mathrm{BiPO}_{4}$ process. T Plant operated form 1944 through 1956. B Plant operated from 1946 through 1952. This carrier precipitation process discharged four wastes to the tank farms: metal, first cycle, second cycle, and 224 wastes. This process recovered plutonium from fuel containing about four percent of all the activity discharged to the tanks. 
Figure C-1. Estimated Hanford Site Tank Waste Radionuclide Inventory. ${ }^{c, d}$

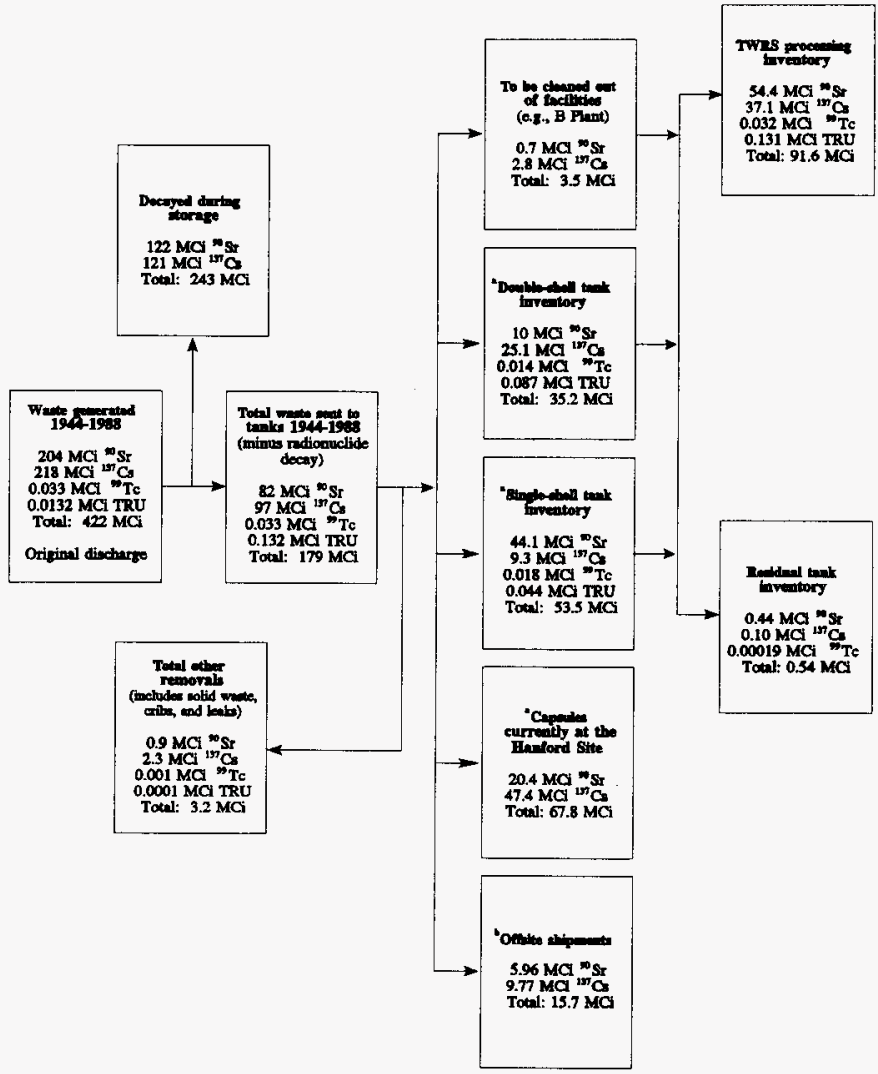

${ }^{a}$ Curie values are based on the Integrated Data Base Report-1994, Rev. 11, Table 2.11 decayed to December 31, 1999.

bThe "offsite shipments" inventory is not expected to return to the Hanford Site for treatment.

${ }^{\mathrm{c} D e c a y}$ products are not listed. Some radionuclides, such as ${ }^{137} \mathrm{Cs}$ and ${ }^{90} \mathrm{Sr}$, have daughters with relatively short half-lives. However, they are present in concentrations associated with the normal decay chains of the radionuclides.

${ }^{\mathrm{d}}$ Inventories of key radionuclides (i.e. ${ }^{3} \mathrm{H},{ }^{129} \mathrm{I},{ }^{14} \mathrm{C},{ }^{79} \mathrm{Se}$, uranium isotopes and ${ }^{126} \mathrm{Sn}$ ) are not shown on the material balance. These radionuclides have small inventories which do not significantly affect the total curies in the material balance. 
The process generated "metal waste" from the initial carrier precipitation step. This waste contained all of the uranium, about 90 percent of the fission product activity, and one percent of the plutonium from the original feed to the process. The process neutralized this acidic waste to a $\mathrm{pH}$ of 7 with sodium hydroxide $(\mathrm{NaOH})$ and treated it with an excess of sodium carbonate before discharging waste to the tanks.

The process generated the first- and second-cycle waste from the second and third carrier precipitation steps. These wastes contained about 10 percent of the fission product activity and two percent of the plutonium from the original feed to the process. The process made these acidic waste alkaline by the addition of $\mathrm{NaOH}$ before discharging it to the tanks.

The process generated the 224 waste during the final purification of the plutonium product. This waste contained almost none of the fission product activity $(<0.001$ percent) and about 0.5 percent of the plutonium from the original feed to the process. The process neutralized and concentrated this waste before discharge to the tanks.

\section{C1.1.2 REDOX Waste}

S Plant discharged waste from the REDOX process from 1952 through 1967 . The waste from this process consisted of HLW components from a methlyisobutylketone solvent extraction process. The REDOX Plant processed about 20 percent of the irradiated fuel discharged from the reactors.

These waste contained essentially all of the fission products in the original feed and small quantities (less than 0.5 percent) of the original plutonium. They contained large amounts of aluminum nitrate used as a salting agent in the solvent extraction process and minor amounts of iron and chromium.

\section{C1.1.3 PUREX Waste}

The PUREX Plant discharged waste from reprocessing of irradiated fuel to the tank farms from 1956 through 1967 and again from 1983 through 1988. The PUREX process used tributyl phosphate (TBP) diluted with kerosene as the extractant. The HLW generated by the PUREX process contained essentially all of the fission products in the original feed plus small amounts of plutonium and uranium also in the waste $(<0.2$ percent). The PUREX Plant reprocessed about 76 percent of the irradiated fuel discharged from the reactors.

Before discharging this waste to the tanks, process steps made the PUREX HLW (principally nitric acid) alkaline by the addition of $\mathrm{NaOH}$. This method of direct storage was used from 1956 through 1967. Beginning in 1968 through 1972, the PUREX Plant transferred the Current Acid Waste (CAW) directly to the fractionation process. As discussed below, the fractionation process removed the cesium and strontium from the waste and returned low heat waste to the tanks. With restart of the PUREX Plant from 1983 through 1988, the neutralized waste was routed to DSTs designed to hold aging waste. 


\section{C1.2 URANIUM RECOVERY WASTE}

U Plant discharged waste from the uranium recovery process from 1952 through 1957 . This process used acid to dissolve uranium-bearing $\mathrm{BiPO}_{4}$ "metal wastes" sluiced from the storage tanks. A solvent extraction process using TBP as the extractant recovered the uranium from the acid feed. After uranium recovery, the process re-neutralized the acidified wastes, treated the waste to precipitate cesium and strontium as $\mathrm{CsNiFe}(\mathrm{CN})_{6}$ and $\mathrm{Sr}_{3}\left(\mathrm{PO}_{4}\right)_{2}$, and discharged the resulting slurries to SSTs to allow the solids to settle.

\section{C1.3 WASTE FRACTIONATION}

In the 1960's, B Plant was modified to recover cesium from the tank waste supernatants and strontium from tank waste sludges. This processing removed decay heat from the waste to allow concentration and in-tank solidification. The process neutralized and returned low heat wastes to the tanks for subsequent concentration and solidification. Wastes were discharged from this process to the tanks from 1968 through 1984.

The use of chelating agents in the fractionation of strontium caused generation of a unique waste type known as CC waste. The organic compounds (e.g., citric acid, ethylenediaminetetraacetic acid) have caused both safety and process concerns in the tank farms. The degradation of the organic compounds has led to elevated hydrogen levels in the tank space above the waste. These same organic compounds solubilize both strontium and transuranic radionuclides which leads to increased concentrations in the supernatants.

\section{C1.4 PLUTONIUM FINISHING PLANT WASTE}

The PFP discharged waste from plutonium processing to the tanks. In recent years, the PFP discharges have gone to tank 241-SY-102 in the 200 West Area.

\section{C1.5 LABORATORY WASTE}

The waste from laboratories supporting processing at the Hanford Site discharge to the tanks.

\section{C1.6 DECONTAMINATION WASTE}

The tanks have received decontamination waste from $\mathrm{T}$ Plant and by rail car shipments from the 100 Areas. T Plant decontamination waste comes from radionuclides removed from equipment before repair and reuse in the plants (e.g., centrifuges). The 100 Area waste came from decontamination of reactor systems such as the $\mathrm{N}$ Reactor primary coolant system. 


\section{C2.0 WASTE EXITING THE TANKS}

Waste has exited the tanks by waste fractionation and by-product recovery, planned and unplanned releases to the soil column, and as contamination on failed equipment. The following sections provide a description of the waste removals from the tanks.

\section{C2.1 WASTE FRACTIONATION AND BY-PRODUCT RECOVERY}

In the past, the waste has undergone extensive processing for by-product recovery as radionuclides packaged in capsules for interim storage and as direct shipment of recovered radionuclides in casks to other DOE sites.

\section{C2.1.1 Cesium and Strontium Capsules}

Beginning in 1967 , cesium and strontium were extracted from the tank waste and purified in B Plant. The fractionated cesium and strontium were encapsulated in the Waste Encapsulation and Storage Facility (WESF). In addition to waste from the tanks, B Plant also received the CAW stream from the PUREX Plant for fractionation and subsequent encapsulation. The DOE stores the capsules in water pools in WESF. The DOE has sent many of the capsules offsite for use in laboratory testing and commercial irradiation, most have been returned.

Table C-1 shows the capsule inventories identified in the July 1995 capsule location quarterly reports (Bender 1995a, b). The quarterly reports give the total number of cesium and strontium capsules produced, the number of capsules located onsite and offsite, and the number of capsules that have been destroyed. In addition, through the effort of the B Plant Capsule Return Program, 95 additional cesium capsules are expected to return from offsite before December 31, 1999. The current radionuclide inventories given in the quarterly reports were decayed to December 31,1999 , for consistency in this report. Table C-1 presents the capsule inventory decayed to December 31, 1999.

Table C-1. Capsule Inventory, MCi. (December 31, 1999, Decay Date).

\begin{tabular}{|c|c|c|c|}
\hline (apsiles & orginal & 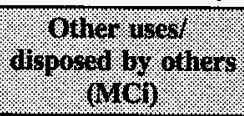 & 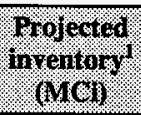 \\
\hline${ }^{137} \mathrm{Cs}$ & 54.8 & 7.29 & 47.5 \\
\hline${ }^{90} \mathrm{Sr}$ & 23.0 & 2.06 & 20.9 \\
\hline Total & 77.8 & 9.35 & 68.4 \\
\hline Total including daughters $\left({ }^{137} \mathrm{Ba},{ }^{90} \mathrm{Y}\right)$ & 152.8 & 18.4 & 134.4 \\
\hline
\end{tabular}

${ }^{1}$ Projected inventory values are generally consistent with the Integrated Data Base Report-1994 (i.e., $47.4 \mathrm{MCi}{ }^{137} \mathrm{Cs}$ and $20.4 \mathrm{MCi}{ }^{90} \mathrm{Sr}$ ). 


\section{C2.1.2 Hanford Atomic Products Operations Cask Shipments}

The Hanford Site began shipping by-product material to the Oak Ridge National Laboratory in 1961 using Hanford Atomic Products Operations (HAPO) casks. The waste shipped in these casks came primarily from PUREX waste and was in the form of ${ }^{137} \mathrm{Cs}$ loaded on an elutable zeolite or ${ }^{90} \mathrm{Sr}$ as a $\mathrm{SrCO}_{3}$ precipitate. The total amount of radionuclides removed from the Hanford Site in HAPO cask shipments is $3.90 \mathrm{MCi}$ of ${ }^{90} \mathrm{Sr}$ and $2.48 \mathrm{MCi}$ of ${ }^{137} \mathrm{Cs}$ (decay date December 31,1999 ), for a total of $6.38 \mathrm{MCi}$ shipped offsite.

\section{C2.2 PLANNED AND UNPLANNED RELEASES TO THE SOIL COLUMN}

The soil column at the Hanford Site contains radionuclides from the waste reprocessing operations. These radionuclides came both from planned and unplanned releases.

\section{C2.2.1 Planned Releases}

In the past, the Hanford Site has used the soil column in the management of radioactive waste. Some of the SST waste was intentionally discharged to the ground via pumping and cascade overflow from 1946 through 1966. The waste discharged to the ground were those that had a low radionuclide concentration which did not require tank storage, but a radionuclide concentration too high to allow discharge to surface ponds. These discharges included: $\mathrm{BiPO}_{4}$ waste, uranium recovery process waste, laboratory wastes, and equipment decontamination wastes which were routed through SSTs before discharge to the ground. Table C-2 shows the waste discharged from the tanks to the soil column (Waite 1992).

Table C-2. Estimated Discharges from Tanks to the Soil Column (December 31, 1999, Decay Date).

\begin{tabular}{|l|c|}
\hline${ }^{137} \mathrm{Cs}$ & Mrct \\
\hline${ }^{90} \mathrm{Sr}$ & 0.0131 \\
\hline${ }^{99} \mathrm{Tc}$ & 0.0108 \\
\hline Transuranics & 0.0009 \\
\hline
\end{tabular}

Also, non-SST waste such as process condensate waste streams from evaporator concentration have been discharged intentionally to the ground from both waste concentration activities and from the process plants. These sources are not significant contributors of ${ }^{90} \mathrm{Sr}$ or ${ }^{137} \mathrm{Cs}$ to soil column discharges. 


\section{C2.2.2 Unplanned Releases}

In addition, unintentional discharge of SST waste has resulted from leaks in tanks and transfer lines and miscellaneous spills. Table C-3, Contaminated Soil Inventory, summarizes the unintentional discharges of SST wastes. The unplanned releases of ${ }^{99} \mathrm{Tc},{ }^{129} \mathrm{~T}$, and nitrate to the soil column was described in the Tank Waste Technical Options Report (Table M2-12, Boomer et al. 1993). The unplanned release of ${ }^{137} \mathrm{Cs}$ is reported as 0.290 to $1.090 \mathrm{MCi}$ (Hanlon 1995). The contaminated soil inventory for the insoluble ${ }^{90} \mathrm{Sr}$ and TRU radionuclides is assumed to be zero for this study.

Table C-3. Estimated Unplanned Releases to the Soil Column (December 31, 1999, Decay Date).

\begin{tabular}{|l|c|}
\hline \multicolumn{1}{|c|}{ Padionudide } & MC \\
\hline${ }^{90} \mathrm{Sr}$ & 0.0 \\
\hline${ }^{99} \mathrm{Tc}$ & 0.00014 \\
\hline${ }^{129} \mathrm{I}$ & 0.0000004 \\
\hline${ }^{137} \mathrm{Cs}$ & 0.290 to 1.090 \\
\hline Transuranics & 0.0 \\
\hline
\end{tabular}

\section{C2.3 SOLID WASTE BURIAL}

Other deductions in the tank waste inventory in the form of solid waste burial of failed equipment from reprocessing plants, B Plant, and WESF processing are shown in Table C-4. The majority of activity was in failed equipment from B Plant and the encapsulation process. The total solid waste burial is provided by the Solid Waste Inventory and Tracking System (SWITS) database (Anderson and Hagel 1995).

Table C-4. Solid Waste Inventory Summary.

\begin{tabular}{|c|c|}
\hline . & 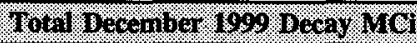 \\
\hline${ }^{90} \mathrm{Sr}$ & 0.90 \\
\hline${ }^{99} \mathrm{Tc}$ & -0 \\
\hline${ }^{137} \mathrm{Cs}$ & 1.18 \\
\hline
\end{tabular}

Radioactively contaminated solid waste has been disposed by burial in the ground since the Hanford Site began operation in 1944. Radioactive waste burials were stopped in the 300 Area in 1972 and in the 100 Areas in 1973. Since 1970, waste suspected of containing transuranic nuclides was segregated and retrievably stored. Thus, the data regarding solid waste burial are in three categories as listed in Table C-4. 
Transuranic waste in the burial grounds is not included in the total inventory values because the material comes from production, did not pass through the tanks, and plays no role in the mass balance for tank waste.

\section{C3.0 TANK WASTE INVENTORY}

The tank waste inventory represents the amount of waste and contained radionuclides that will be ultimately processed by pretreatment and LAW and HLW vitrification. The TWRS processing inventory consists of the current tank inventory and future additions less the tank heel following waste retrieval. The processing inventory is discussed in the following sections.

\section{C3.1 CURRENT TANK INVENTORY}

Table C- 5 contains the tank waste inventory for selected radionuclides decayed to December 31, 1999 (DOE 1994). The inventories presented here use the data proposed for the 1995 Integrated Data Base report (Shelton 1995), which provides the soluble and insoluble fractions for the tank waste.

Table C-5. Tank Inventory (December 31, 1999, Decay Date).

\begin{tabular}{|c|c|c|c|}
\hline \multirow{2}{*}{ Radionuclide } & \multicolumn{3}{|c|}{ Tank yaste Inventoy, MCl } \\
\hline & Solvble & Trsoluble & Trota: \\
\hline${ }^{90} \mathrm{Sr}$ & 1.89 & 52.2 & 54.1 \\
\hline${ }^{137} \mathrm{Cs}$ & 31.4 & 3.01 & 34.4 \\
\hline TRU & 0.00961 & 0.121 & 0.131 \\
\hline${ }^{99} \mathrm{Tc}$ & 0.0228 & 0.00930 & 0.0321 \\
\hline Total & 33.3 & 55.3 & 88.6 \\
\hline $\begin{array}{l}\text { Tank total including } \\
\text { daughters }\left({ }^{137} \mathrm{Ba},{ }^{90} \mathrm{Y}\right)\end{array}$ & 65.0 & 110.0 & 175.6 \\
\hline
\end{tabular}

\section{C3.2 FUTURE TANK ADDITIONS}

The Hanford Site no longer has a production mission and no reprocessing waste will be discharged to the tanks. Facility deactivation provides the primary source of future tank waste. The future tank additions are shown in Table C-6. The majority of this waste will come from B Plant. The flushing of approximately $3 \mathrm{MCi}$ of cesium and strontium from B Plant to the tanks is based on $B$ Plant Transition Engineering Radioactive Inventory and Material Status (RIMS) (Gehrke 1995). For mixed inventories reported by Gehrke, the estimated ${ }^{90} \mathrm{Sr} /{ }^{137} \mathrm{Cs}$ inventory was assumed to be a $50 / 50$ split. The maximum B Plant inventory, reported in a range, is used in this study. 
Table C-6. Future Tank Additions.

\begin{tabular}{|c|c|c|}
\hline \multirow{2}{*}{ B Plant Inventory } & \multicolumn{2}{|c|}{ Mä, December 31 , 1999. Becay Date } \\
\hline & 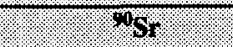 & 187Cs: \\
\hline Radioactive process liquid & 0.0146 & 0.0147 \\
\hline Radioactive filter & 0.101 & 0.587 \\
\hline Residual inactive process and facility & 0.0925 to 0.589 & 0.336 to 2.168 \\
\hline Total & 0.2 to 0.7 & 0.9 to 2.8 \\
\hline
\end{tabular}

\section{C3.3 RESIDUAL TANK INVENTORY}

The residual amount of tank inventory contained in the tank heels at completion of the retrieval operation has not yet been determined and is subject to a separate NRC determination. For purposes of this study, the residual tank inventory is assumed to be 0.05 percent of the DST inventory (DOE 1987) and 1 percent of the SST inventory (Ecology 1994). The residual SSTs inventory are based on the Integrated Database Report 1995 inventories. For the DSTs, the inventory is based on the Integrated Database Report 1995 inventories along with the future tank additions (Table C-6). Table C-7 shows the estimated residual tank inventory.

Table C-7. Estimated Residual Tank Inventory.

\begin{tabular}{|c|c|c|c|c|}
\hline \multirow{2}{*}{ Tank Waste: } & \multicolumn{4}{|c|}{ Mre, Decenber 31,1999 , Decay Date } \\
\hline & isis & siges & 97. & Transuranics \\
\hline $\begin{array}{l}\text { Current double-shell tank (DST) } \\
\text { Inventory }\end{array}$ & 10 & 25.1 & 0.014 & 0.087 \\
\hline Future DST Additions & 0.7 & 2.8 & 0 & 0 \\
\hline Estimated Future DST Inventory & 10.7 & 27.9 & 0.014 & 0.087 \\
\hline Residual DST Inventory & 0.005 & 0.012 & $7.0 \mathrm{E}-06$ & $4.3 \mathrm{E}-05$ \\
\hline Single-shell tank (SST) Inventory & 44.1 & 9.3 & 0.018 & 0.044 \\
\hline Residual SST Inventory & 0.44 & 0.093 & $1.8 \mathrm{E}-04$ & $4.4 \mathrm{E}-04$ \\
\hline Estimated Residual Tank Inventory & 0.44 & 0.10 & $1.9 \mathrm{E}-04$ & $4.8 E-04$ \\
\hline
\end{tabular}




\section{C3.4 TANK WASTE REMEDIATION SYSTEM PROCESSING INVENTORY}

Table C- 8 presents the total inventory of radionuclides that will be processed by pretreatment. The total inventory includes the current tank inventory (Table C-5, Section C3.1) plus the radionuclide inventory to be flushed from B Plant (Table C-6, Section C3.2) less the residual tank inventory (Table C-7, Section C3.3). The ${ }^{90} \mathrm{Sr}$ additions and deletions are in the insoluble fraction. The ${ }^{137} \mathrm{Cs}$ additions and deletions are in the soluble fraction.

The inventories of ${ }^{3} \mathrm{H},{ }^{14} \mathrm{C}$, and ${ }^{129} \mathrm{I}$ are given in Colby (1994). The inventory for ${ }^{79} \mathrm{Se}$ is given in Mann et al. (1995).

Table C-8. Estimated Tank Waste Remediation System Processing Inventory (December 31, 1999, Decay Date).

\begin{tabular}{|c|c|c|c|}
\hline \multirow{2}{*}{ Rafloniclides } & \multicolumn{3}{|c|}{ Tank Waste Remedindion Systen Irocessing In rentory, MCI } \\
\hline & Soluble & Insolinilie & rotal : \\
\hline${ }^{90} \mathrm{Sr}$ & 1.89 & 52.5 & 54.4 \\
\hline${ }^{137} \mathrm{Cs}$ & 34.1 & 3.01 & 37.1 \\
\hline Transuranics & 0.00961 & 0.121 & 0.131 \\
\hline${ }^{99} \mathrm{Tc}$ & 0.0228 & 0.0093 & 0.0321 \\
\hline${ }^{3} \mathrm{H}$ & 0.01 & - & 0.01 \\
\hline${ }^{14} \mathrm{C}$ & 0.0053 & - & 0.0053 \\
\hline${ }^{79} \mathrm{Se}$ & 0.00103 & - & 0.00103 \\
\hline${ }^{129} \mathbf{I}$ & 0.000051 & - & 0.000051 \\
\hline Total & 36.0 & 55.6 & 91.6 \\
\hline $\begin{array}{l}\text { Tank total including } \\
\text { daughters }\left({ }^{90} \mathrm{Y},{ }^{137} \mathrm{Ba}\right)\end{array}$ & 71.4 & 110.0 & 181.4 \\
\hline
\end{tabular}




\section{C4.0 REFERENCES}

Anderson, J. D., and D. L. Hagel, 1995, Summary of Radioactive Solid Waste Received in the 200 Areas During Calendar Year 1994, WHC-EP-0125-7, Westinghouse Hanford Company, Richland, Washington.

Bender, K. P., 1995a, Quarterly Report: Location of WESF Cesium Capsules, Internal Memo 16800-95-KPB-003, Westinghouse Hanford Company, Richland, Washington.

Bender K. P., 1995b, Quarterly Report: Location of WESF Strontium Capsules, Internal Memo 16800-95-KPB-004, Westinghouse Hanford Company, Richland, Washington.

DOE, 1994a, Integrated Data Base Report - 1994, U.S. Spent Nuclear Fuel and Radioactive Waste Inventories, Projections, and Characteristics, DOE/RW-0006, Rev. 11, U.S. Department of Energy, Richland, Washington.

Ecology, EPA, and DOE, 1994, Hanford Federal Facility Agreement and Consent Order, as amended, Washington State Department of Ecology, U.S. Environmental Protection Agency, and the U.S. Department of Energy, Olympia, Washington.

Gehrke, J. W., 1995, B Plant Transition Engineering Radioactive Inventory and Material Status (RIMS), Internal Memo to W. W. Bowen, 16550-95-JWG-053, Westinghouse Hanford Company, Richland, Washington.

Hanlon, B. M., 1995, Waste Tank Summary Report for Month Ending August 31, 1995, WHC-EP-0182-89, Westinghouse Hanford Company, Richland, Washington.

Shelton, L. W., 1995, Radionuclide Inventory for Single- and Double-Shell Tanks, Internal Memo 71320-95-002, Westinghouse Hanford Company, Richland, Washington. 
WHC-SD-WM-TI-699, Rev. 1

This page intentionally left blank. 


\section{DISTRIBUTION SHEET}

\begin{tabular}{|c|c|c|c|c|c|}
\hline \multirow{2}{*}{$\begin{array}{l}\text { To } \\
\text { Storage and Disposal Project }\end{array}$} & \multirow{2}{*}{\multicolumn{3}{|c|}{$\begin{array}{l}\text { From } \\
\text { Process Technology }\end{array}$}} & \multicolumn{2}{|l|}{ Page 1 of 1} \\
\hline & & & & \multicolumn{2}{|c|}{ Date $7 / 15 / 96$} \\
\hline \multicolumn{4}{|l|}{ Project Title/Work Order } & \multicolumn{2}{|l|}{ EDT No. } \\
\hline \multicolumn{4}{|c|}{$\begin{array}{l}\text { Technical Basis for Classification of Low-Activity Waste } \\
\text { Fraction from Hanford Site Tanks, WHC-SD-WM-TI-699, Rev. } 1\end{array}$} & \multicolumn{2}{|c|}{ ECN No. 623790} \\
\hline Name & MSIN & $\begin{array}{c}\text { Text } \\
\text { With All } \\
\text { Attach. }\end{array}$ & Text Only & $\begin{array}{l}\text { Attach./ } \\
\text { Appendix } \\
\text { Only }\end{array}$ & $\begin{array}{l}\text { EDT/ECN } \\
\text { Only }\end{array}$ \\
\hline
\end{tabular}

Central Files (2)

DOE Public Reading Room

S. K. Baker

A. L. Boldt

D. A. Burbank

R. D. Claghorn

E. A. Fredenburg

J. S. Garfield

K. A. Gasper

J. 0 . Honeyman

M. J. Klem

E. J. Kosiancic

M. J. Kupfer

F. M. Mann

R. P. Marshall

R. J. Murkowski

R. M. Orme

C. A. Petersen (5)

R. W. Powell

I. E. Reep

P. S. Schaus

J. W. Shade

E. J. Slaathaug

J. P. Sloughter

J. A. Swenson

J. A. Voogd (5)

D. J. Washenfelder

G. F. Williamson

BNFL, Inc ,

1835 Terminal Drive

Richland, Washington 99352

L. M. Swanson

R. Tooze

$\begin{array}{ll}A 3-88 & X \\ H 2-53 & X\end{array}$

H5- 49

H5- 49

H5--27

H5- 49

H5-61

H5- 49

G3-21

G3-21

H5 -27

H5-61

H5-27

HO-31

H5-61

H5-03

H5-27

H5-27

G3-21

G3-21

G3-21

H5-27

H5- 49

R2-54

R3-11

H5- 03

H5- 27

H5-03
$X$
$X$

$X$

$x$

$x$

$x$

$X$

$X$

$X$

$X$

$x$

$x$

$X$

$x$

$x$

$X$

$X$

$x$

$x$

$x$

$x$

$x$

$x$

$x$

$x$

$x$

$x$

$x$

Los Alamos Technical Assosiates, Inc.

309 Bradley 81 vd.

Richland, Washington 99352

M. M. McCarthy

$\begin{array}{ll}G 6-81 & X \\ G 6-81 & X\end{array}$ 